EVOLUÇÃO GEOQUIIMICA, MINERALÓGICA E MICROMORFOLÓGICA NO PROCESSO DE BAUXITIZAÇÃO. ESTUDO COMPARATIVO DOS DEPÓSITOS DE MOGI DAS CRUZES, CURUCUTU E LAVRINHAS, SP, ASSOCIADOS A DIFERENTES TIPOS LITOLÓGICOS.

Dissertação de Mestrado apresentada ao Instituto de Geociências da Universidade de São Paulo. 
MARIA CRISTINA TOLEDO GROKE

EVOLUÇÃO GEOQUIIMICA, MINERALÓGICA E MICROMORFOLÓGICA NO PROCESSO DE BAUXITIZAÇÃO. ESTUDO COMPARATIVO DOS DEFÓSITOS DE MOGI DAS CRUZES, CURUCUTU E LAVRINHAS, SP, ASSOCIADOS A DIFERENTES TIPOS LITOLÓGICOS.

Dissertação de Mestrado apresentada ao Instituto de Geociências da Universidade de São Paulo.

Orientador :

Prof. Dr. Adolpho José Melfi
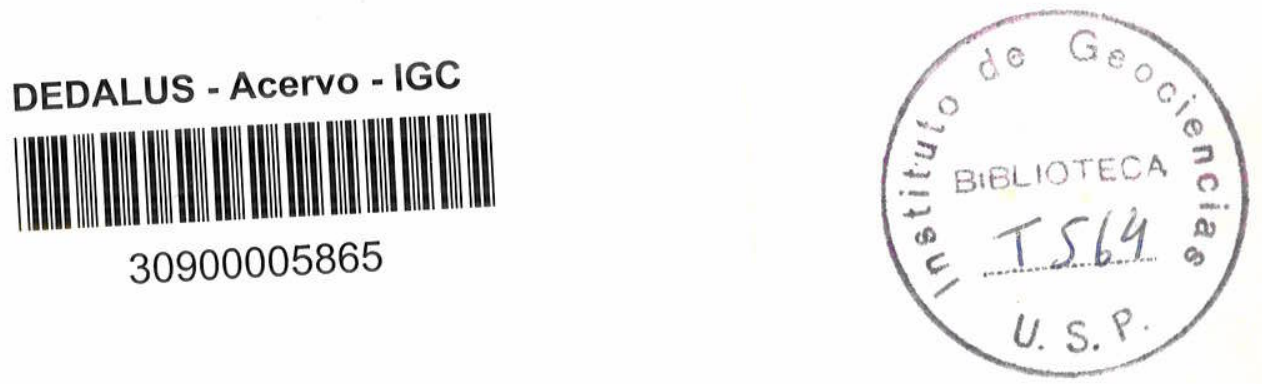
I - INTRODUÇÃO

1. Generalidades 1

2. Objetivos 2

3. Revisão Bibliogrāfica 3

3.1. A alteração hidrolîtica 3

3.2. A formação de bauxitas 11

4. Areas de Estudo 18

4.1. Mogi das Cruzes 21

4.2. Curucutu 22

4.3. Lavrinhas 23

II - MATERIAIS E METODOS

1. Materiais 29

2. Métodos 29

2.1. Anālise Granulomētrica 32

2.2. Densidade Aparente 32

2.3. Anālise Mineralōgica por Difração de Raios-X 33

2.4. Anālise Mineralōgica por A.T.D. 34

2.5. Anālise Micromorfolōgica 34

2.6. Anāitises Quĩmicas 36

2.6.a - Dosagem de $\mathrm{H}_{2} \mathrm{O} 36$

2.6.b - Dosagem de sîlica 36

2.6.c - Dosagem de cāicio 36

2.6.d - Dosagem dos elementos maiores 36

2.6.e - Dosagem dos elementos menores e traços 37

II - RESULTADOS E DISCUSSÖES

1. Evolução Mineralōgica e Micromorfológica dos Materiais 38

1.1. Rochas de composição granītica,Mogi das Cruzes 38

1.2. Rochas bāsicas, Curucutu 45

1.3. Rochas alcalinas, Lavrinhas 51

1.4. Discussão 55 
2. Evolução Quĩmica dos Materiais

2.1. Resultados 63

2.2. Discussão 70

IV - CONSIDERAÇOES FINAIS

1. Controles Atuantes na Bauxitização 74

2. Processos de Bauxitização 76

3. Caracterização Geoquĩmica dos Processos de Bauxitização

4. Cronologia das Alterações

AGRADECIMENTOS 


\section{INDICE DAS FIGURAS}

Figura 1 - Superposição da curva estequiomëtrica e da curva de dissolução simulada da olivina.

Figura 2 - Diagrama $C / t=f(C)$, da concentração em sĩlica a 40 o. .

Figura 3 - Distribuição da formação de bauxitas no tempo geolögico

Figura 4 - Distribuição dos depōsitos bauxĩticos formados durante o Devoniano.

Figura 5 - Distribuição das bauxitas formadas durante. 0 Eoceno mëdio.

Figura 6 - Mapa de localização das āreas de estudo.

Figura 7 - Mapa geolögico regional do nordeste paulista.

Figura 8 - Perfis tīpicos amostrados para as três äreas de estudo.

Figura 9 - Fluxograma dos trabalhos de laboratōrio.

Figura 10 - Alteração das rochas com quartzo.

Figura 11 - Evolução dos microssistemas de alteração nas ro chas com quartzo.

Figura 12 - Alteração das rochas bāsicas.

Figura 13 - Evolução dos microssistemas de alteração nas rochas bãsicas.

Figura 14 - Alteração das rochas alcalinas 
Figura 15 - Evolução dos microssistemas de alteração nas rochas alcalinas.

Figura 16 - Desestabilização dos minerais primärios e aparecimento dos minerais secundārios nos perfis de alteração dos materiais estudados.

Figura 17 - Solubilidade do alumĩnio em função do pH.

Figura 18 - Diagrama de estabilidade para alguns minerais no sistema $\mathrm{Al}_{2} \mathrm{O}_{3} \cdot \mathrm{SiO}_{2} \cdot \mathrm{H}_{2} \mathrm{O}$, a $250 \mathrm{C}$ e $1 \mathrm{~atm}$.

Figura 19 - Variação dos teores absolutos $(\mathrm{g} / 100 \mathrm{cc})$ dos diversos óxidos, em função da densidade aparente $(g / c c)$, para o nefelina-sienito e seus produtos de alteração.

Figura 20 - Variação dos teores absolutos $(\mathrm{g} / 100 \mathrm{cc})$ dos diversos ōxidos, em função da densidade apa rente $(g / c c)$, para o diabásio e seus produtos de alteração.

Figura 21 - Quadro simplificado da evolução dos materiais estudados.

\section{INDICE DAS TABELAS}

Tabela 1 - Composição quîmica, em \% peso, do diabāsio, ne felina-sientios e seus produtos de alteração.

Tabela 2 - Teores de elementos menores e traços

nos materiais estudados, em ppm.

Tabela 3 - Composição quimica dos horizontes remobilizados, provenientes da alteração de rochas gra niticas, em \% peso.

Tabela 4 - Composição quĩmica, expressa em porcentagens volumëtricas $(\mathrm{g} / 100 \mathrm{cc})$, do diabāsio, nefelina 
Tabela 5 - Balanço geoquỉmico para a alteração do diabäsio e dos nefelina-sienitos (média).

Tabela 6 - Perdas (-) e ganhos (+), em porcentagens, apresentados pelas amostras em relação à rocha sã.

\section{INDICE DAS FOTOGRAFIAS}

Fotografias dos locais estudados (fotos 1 a 10)

Fotomicrografias dos principais aspectos das lâminas delgadas (fotomicrografias 1 a 18). 
I. INTRODUÇAOO

1. Generalidades

0 processo de intemperismo quimico das rochas sob clima tropical è de fundamental importāncia na gênese de certos tipos de jazidas minerais, classificadas como lateriticas. Este tipo genētico engloba importantes depōsitos de alumīnio, nịquel, manganés, crömio, entre outros, encontrados em todas as regiões do globo onde houve condiçôes propicias à Taterização, no decorrer do tempo geolögico.

A formação de tais depōsitos se dā essencialmente a partir da interação dos agentes da dinämica externa com a $1 j$ tosfera,que nesses casos resulta num processo de alteração hidro 17 tica.

A litologia, pelo seu potencial geoquímico, e tambēm por todas as suas outras caracterīsticas, mineralōgicas, texturais e estruturais, exerce um papel preponderante nestes fe nōmenos, favorecendo ou não o processo de intemperismo quĩmico,e possibilitando acumulações de determinados elementos. Desta forma, explica-se as concentrações de $\mathrm{Ni}$ e $\mathrm{Cr}$ associadas à alteração laterîtica de rochas ultramäficas, concentrações bauxîticas associadas a rochas alcalinas e bäsicas, entre outros casos.

Confirmando esta ültima associação, temos no Brasil, a exemplo de värios outros paîses, expressivas jazidas bau$x \ddot{i t i c a s,}$ geneticamente 1 igadas à alteração de rochas alcalinas (Poços de Caldas - MG; Lages-SC; Passa-Quatro e Itatiaia - MG e $S P)$. Estas rochas, pobres em silicio, ferro e ricas em aluminio, são favorāveis à alitização (Pedro, 1964), pois sua composição quase exclusiva de aluminossilicatos, favorece a atuação dos mecanismos hidrolitticos, promovendo a eliminação total do silicio e bases do meio eluvial, e a conseqdente acumulação do aluminio.

A ausēncia de quartzo neste tipo de rocha é geral mente considerada fundamental (Gardner, 1970). Segundo Kittrick (1969), a atividade em $\mathrm{H}_{4} \mathrm{SiO}_{4}$ determina o mineral a ser precipitado nas neogēneses (silica amorfa, montmorilonita, caolinita ou 
gibbsita), e o argumento usado quando se defende a necessidade da ausēncia de quartzo no sistema ē que, em sua presença, o nīvel em sīlica dissolvida nas āguas de alteração nunca será baixo o suficiente para a formação de gibbsita.

Nos solos de basaltos do Brasil meridional ocorre uma intensa gibbsitização, com altos teores em $\mathrm{Al}_{2} \mathrm{O}_{3}$, sem a presença, contudo, de jazidas bauxiticas exploräveis, como as existentes na Africa, em formações correlacionāveis litológica e climaticamente. Neste caso, a diferente evolução tectōnica e geomorfolōgica è que determinou a não separação Fe-Al nas formações do sul do Brasil.

Um caso à parte refere-se à associação de depōsitos bauxïticos com rochas exibindo sïlica livre em sua composição. Na Serra do Mar e da Mantiqueira, no estado de São Paulo, ocorrem jazidas e depōsitos bauxīticos formados a partir de rochas de com posição granītica, atravēs de um mecanismo não muito bem conhecido do ponto de vista fīsico-quīmico, mecanismo este em que devem ter atuado agentes que promoveram a total dissolução dos aluminos silicatos presentes e a preservação do quartzo. Neste caso, é evi dente que a solução de alteração, em contato com a rocha, deve ter tido sempre uma atividade em sïlica suficientemente baixa para que o equilíbrio do sistema $\mathrm{SiO}_{2} \cdot \mathrm{Al}_{2} \mathrm{O}_{3} \cdot \mathrm{H}_{2} \mathrm{O}$ estivesse sempre dentro do campo de estabilidade da gibbsita (Kittrick, op.cit.).

\section{Objetivos}

Conhecendo-se a influência exercida pela rocha na gênese destas jazidas, e sendo sobretudo os parāmetros de composi ção quīmica e mineralōgica que estão envolvidos, foi objetivo des te trabalho caracterizar a evolução apresentada por rochas perten centes a uma mesma sērie geoquīmica, sialfērrica, mas de sequências mineralögicas distintas, quais sejam, sequēncias quartzofeldspāticas e feldspāticas, durante o processo de laterização com enriquecimento em alumínio.

Desta forma, tentou-se não sō estabelecer as fi1iações mineralögicas, mas tambēm determinar a organização micro- 
estrutural dos minerais presentes nas värias fases da alteração e sua influência na evolução dos minerais primärios e secundärios durante o fenōmeno de bauxitização observado nos materiais.

\section{Revisão Bibliogrāfica}

3.1. A alteração hidrolitica

Os mëtodos clässicos de estudo da alteração superficial das rochas e pedogēnese são mētodos globais, que se ca racterizam por considerar homogêneos os diversos horizontes de alteração ou pedogenëticos, definindo a evolução do conjunto dos perfis, comparados ao material inicial, isto ë, definindo o processo "mëdio" atuante na alteração e na pedogênese do material analisado.

Um dos mëtodos utilizados no estudo da alteração hidrolîtica, o mëtodo geoquímico, baseia-se na caracterização dos principais minerais secundārios silico-aluminosos resultantes da evolução superficial, pois, dispondo-se da composição química desses minerais secundārios e dos minerais primärios da rocha original, pode-se estabelecer o balanço de matéria resultante da evolução hidrolîtica, utilizando-se a teoria da existência de três grandes possibilidades mineralögicas na alteração: alitização, monossialitização e bissialitização (Harrassowitz, 1926, e Pedro, 1964, 1966). A cada um dos très processos corresponde uma composição quîmica bem determinada da fase solüvel, que neste caso contēm essencialmente a sîlica e os cātions básicos solubiliza dos a partir da destruição do silicato inicial. Na realidade, porēm, a alteração superficial se produz em sistema aberto, de maneira que as āguas são continuamente renovadas, sendo impossível estabelecer um balanço global entre o inicio e o final da alteração do mineral primārio (Pedro, 1979).

Assim, considerando-se que a cada instante da a lteração, as proporções dos elementos em solução correspondem às proporções perdidas pelo mineral primärio, é possível caracteri zar as diversas reações de evolução da alteração; neste caso, con 
sidera-se o comportamento dos elementos solubilizados, em valor relativo, em cada momento do desenvolvimento do fenōmeno.

Eneste contexto que se inclui a proposta de uti lização de parâmetros geoquĩmicos na definição da alteração, como $R=\left(\frac{\mathrm{SiO}_{2}}{\text { bases da rocha }}\right), R_{k}=\left(\frac{\mathrm{SiO}_{2} \text { não caolinizävel }}{\text { bases da rocha }}\right), L=\left(\frac{\mathrm{SiO}_{2}}{\text { bases da ägua }}\right)$ (Pedro, 1964).

0 mëtodo geoquīmico, alëm de testado inicialmente ao curso de estudos experimentais, (Pedro, op.cit.), foi veri ficado no meio natural (Tardy, 1969).

Segundo Pedro (1979), a aplicação do mëtodo não encontra problemas na zona intertropical, onde os minerais secun därios formados têm uma composição constante e bem determinada (gibbsita-caolinita). Torna-se, contudo, problemätica, quando a plicada em regiões temperadas, onde os constituintes formados pó dem ser de natureza diversa e de composição muito mais variada, como as argilas micäceas (esmectitas: montmorillonitas, beidelli ta, nontronita; vermiculita e illitas).

Dai a necessidade de um mëtodo mais completo, que possa ser aplicado independentemente da mineralogia do material secundärio, o mētodo termodinämico.

A aplicação da termodinâmica, impulsionada principalmente por Garrels (Garrels e Howard, 1957; Garrels e Christ, 1965), baseia-se essencialmente na hipōtese de que os minerais estão em equilitbrio no meio superficial, com as äguas que os banham. Nesta visão, as reações de alteração tornam-se verdadeiras reações quĩmicas, às quais se pode aplicar as leis do equilïbrio químico e, em particular, a lei de ação das massas, que significa a existēncia de uma relação quantitativa, no equilíbrio, entre as atividades das espēcies dissolvidas na ägua. Procedendo - se desta maneira, admite-se implicitamente que nos fenōmenos de alteração, a dissolução dos minerais primärios ē congruente, e que as reações são estequiomëtricas. Alëm disso, convëm ressal tar que a termodinâmica dos equilíbrios quĩmicos refere-se a sis 
temas reversĩveis, enquanto que as reações de alteração são, ao conträrio, irreversiveis. Com o trabalho de Helgeson (1968), pro pondo o conceito de alteração como uma sucessão de equilíbrios parciais, o mētodo termodinämico iniciou seu desenvolvimento, se guindo-se uma sērie de trabalhos, entre os quais Helgeson (1969), Michard (1974), Fritz (1976), Fritz e Tardy (1976), Massard (1977), que possibilitaram um avanço na resolução dos problemas, podendo-se dizer do mëtodo termodinâmico que: a) baseia- se na termodināmica dos processos irreversiveis, que considera o conceito de equilibrio local; o ünico processo irreversîvel $\vec{e}$ a dissolução do mineral, e todos os outros constituintes (comple xos, minerais de neoformação), são supostos em equilíbrio entre eles e com as soluções; b) a estequiometria das reações evolui ao curso de seu avanço, e seus coeficientes podem ser calculados, segundo Helgeson (1968).

Neste mëtodo tem-se, portanto, a possibilidade de avaliação das diversas transferēncias de massa inerentes à al teração hidrolîtica e, ao mesmo tempo, melhor precisar as condi ções reinantes durante a evolução da alteração.

Contudo, uma vez atingido este estägio de conhecimentos, tornou-se necessārio modificar os mëtodos de estudo pois, por um lado, o mëtodo termodinâmico era freado pela falta de dados (constantes de equilibrio), e por outro lado, tornou-se importante considerar não mais apenas as possibilidades reacionais, mais as reações que se produzem efetivamente. Delmas (1979), mostrou que as dificuldades se resumiam a problemas de cinëtica, e que ē possỉvel hoje, desenvolver um conceito de alte ração que repousa sobretudo nas velocidades das reações.

Neste trabalho citado, Delmas explica que a partir do momento em que se considera que cada reação quïmica se de senvolve com uma velocidade que the ē pröpria, poder-se-ä com a ajuda da cinëtica, analisar uma sequéncia de alteração, e identi ficar as suas diversas etapas.

Em suma, ë necessärio que a cinētica de uma das etapas seja perfeitamente conhecida e sirva de referência ao conjunto. Os mecanismos da reação são assim identificados,e po- 
dem ser estudados por eles pröprios.

Segundo a teoria de Helgeson (1968), as neoforma ções aparecem à medida que aumenta a concentração da solução. 0 desenvolvimento da sequēncia é portanto ligado ao avanço da solu bilização, ou seja, à velocidade da dissolução. Sendo um fator limitante, a reação de dissolução tem um papel privilegiado, e tem sido a mais efetivamente estudada.

Temos que a solubilização dos silicatos $\overrightarrow{\mathrm{e}}$ uma reação particular em dois aspectos: trata-se de uma reação complexa, e não estequiomētrica, isto $\bar{e}$, a solução tem uma composição quĩmica diferente do mineral que se dissolve.

A falta de estequiometria na solubilização dos silicatos, problema fundamental das pesquisas cinēticas, provo cou o surgimento de duas teorias que tentam explicā-la, atravēs da existēncia de um cōrtex envolvente de composição diferente da do mineral; essas teorias são a teoria da camada neoformada (Correns e Engelhardt, 1938 e Wollast, 1967), e a teoria da troca iōnica, ou do cörtex de difusão (Jenny, 1951 e Garrels e Howard, 1957).

A lạ teoria propõe que a causa da falta de este quiometria na dissolução estā na precipitação de um silicato neo formado na superfĩcie dos cristais em alteração, o que significa ria tambëm uma barreira fĩsica à difusão, controlando a velocida de da reação. A outra teoria supõe que os cätions do mineral podem ser trocados com os $\mathrm{H}^{+}$da ăgua, formando uma camada perifēri ca onde a rede cristalina foi modificada por essa troca.

Contudo, pesquisadores como Petrovic et al (1976) e Berner (1977), não encontraram diferença de composição quimica entre a superfície e o interior do cristal de feldspatos em alteração, o que leva a crer na inexistência de cörtex algum, e que a dissolução dos feldspatos se faz estequiometricamente,correspondendo a uma dissolução verdadeira.

Delmas (op.cit.), aplicando a cinëtica a uma rea ção de alteração, no caso a dissolução de olivina, medindo a com 
posição da solução em cada instante, mostrou que o caminho rea cional da alteração de uma olivina comporta ao menos quatro etapas, esquematizadas no gräfico da figura 1, que compara a curva de dissolução congruente da olivina, com solubilização simultânea para a sijlica e o oxido de magnësio, com as curvas obtidas experimentalmente para a solubilização de ambos os öxidos na dis solução simulada da olivina. Na parte I do gräfico, observa- se que existe em solução mais $\mathrm{SiO}_{2}$ que Mgo, mostrando que houve uma dessilicificação do mineral, com formação de um cörtex pobre em sîlica. Na parte II, as curvas de solubilização são todas coinci dentes, caracterizando uma etapa de dissolução verdadeira. A par te III pode ser subdividida em duas; na primeira, a solubilização tanto da $\mathrm{SiO}_{2}$ como do MgO se mostra abaixo da curva de disso Tução congruente, o que sugere a neoformação de um cörtex, mais silicoso que a olivina, pois hä em solução menos sïlica que óxido de magnēsio; na ültima parte, a solubilização da $\mathrm{SiO}_{2}$ e do Mgo se torna muito superior ao limite da dissolução congruente,o que somente pode ser explicado pela formação de complexos sĩlico -magnesianos, permitindo que as concentrações em $\mathrm{SiO}_{2}$ e em Mgo em solução, ultrapassem os limites de sua solubilidade.

Delmas pondera que essas etapas representam o ünico caminho reacional compativel com os valores das velocidades das reações, entre todos os caminhos termodinamicamente possĩveis.Alēm disso, a identificação de uma fase de formação de complexos não poderia ser feita pelos outros métodos anteriormen te utilizados, sendo conveniente ressaltar que a formação de com plexos representa uma etapa reacional importante, não. prevista nos cälculos de equilibrios.

Mas a cinētica encontra ainda outras aplicações nos estudos de alteração, como a definição exata da solubilidade congruente de um silicato, ou ainda a determinação da alterabili dade de um mineral, e assim, da sequência de alterabilidade dos minerais.

Sabe-se que a solubilidade de um silicato è muito dificil de ser determinada, pois o equilibrio raramente $\bar{e}$ atingido, e nem sempre se sabe a que corresponde este equilibrio, devido à falta de estequiometria da reação de dissolução. Segun- 


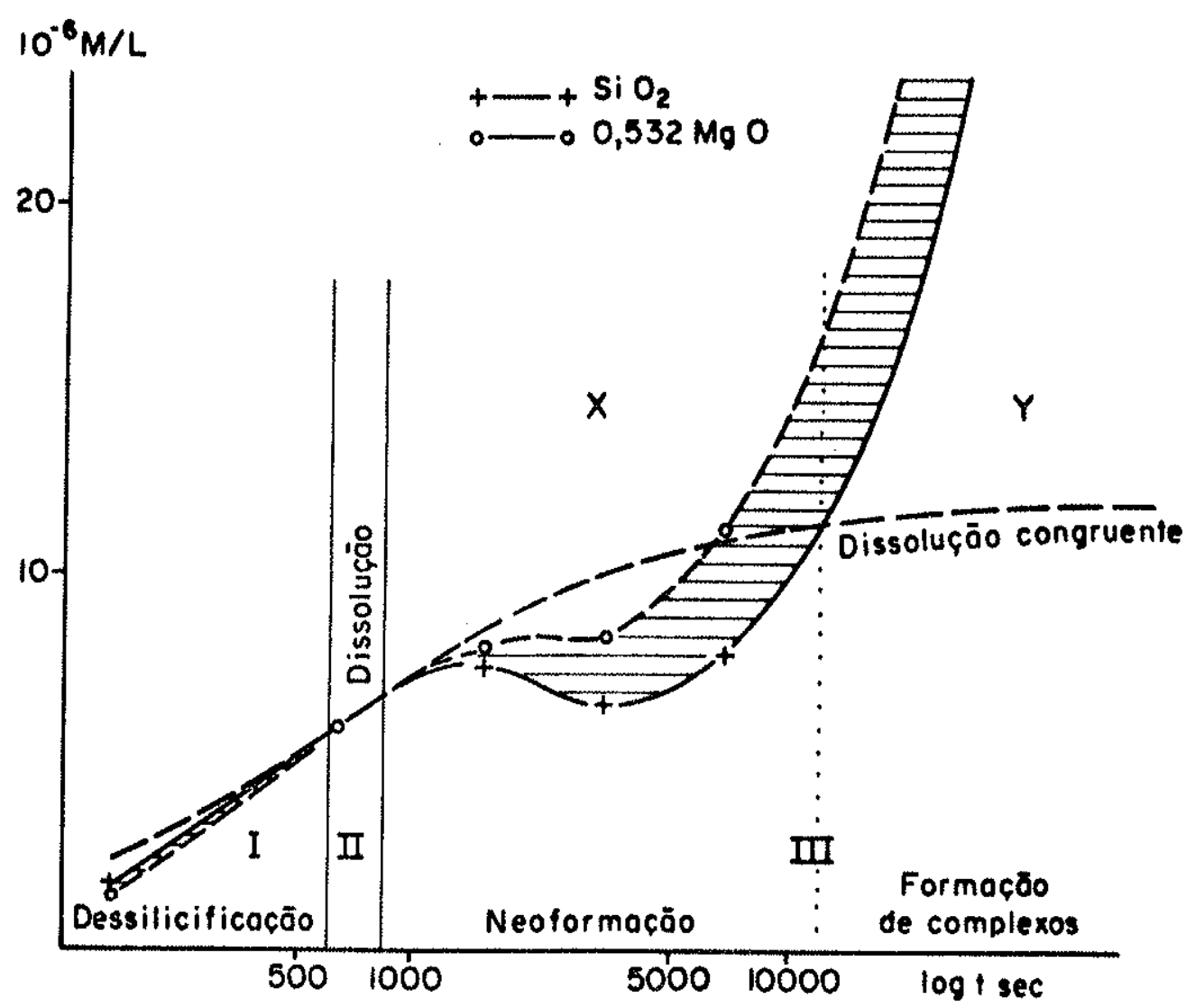

Fig.I- SUPERPOSIÇÃO DA CURVA ESTEQUIOMÉTRICA E DA CURVA DE DISSOLUCCAOO SIMULADA DA OLIVINA. FONTE:

(A.B. Delmos, 1979.)

do o trabalho desenvolvido por Delmas, este problema pode ser consideravelmente simplificado, admitindo-se que a solubilidade corresponde ao estado final de uma reação de dissolução, onde a velocidade da reação ē nula, ou seja, onde não é possīvel contj nuar a reação. 0 valor pode ser obtido a partir da extrapolação da curva de dissolução, que representa a velocidade em função da concentração na solução, e foi chamado por Delmas de solubilidade cinética (Co) (figura 2).

A outra aplicação da cinētica, com respeito à de terminação da alterabilidade de um mineral, foi tambēm apresentá da por Delmas. Pode-se dizer que a alterabilidade de um mineral em meio aquoso é proporcional à sua velocidade de dissolução,que depende, em cada instante, do estado do meio e de sua concentração. Teremos uma medida da alterabilidade potencial mäxima de 


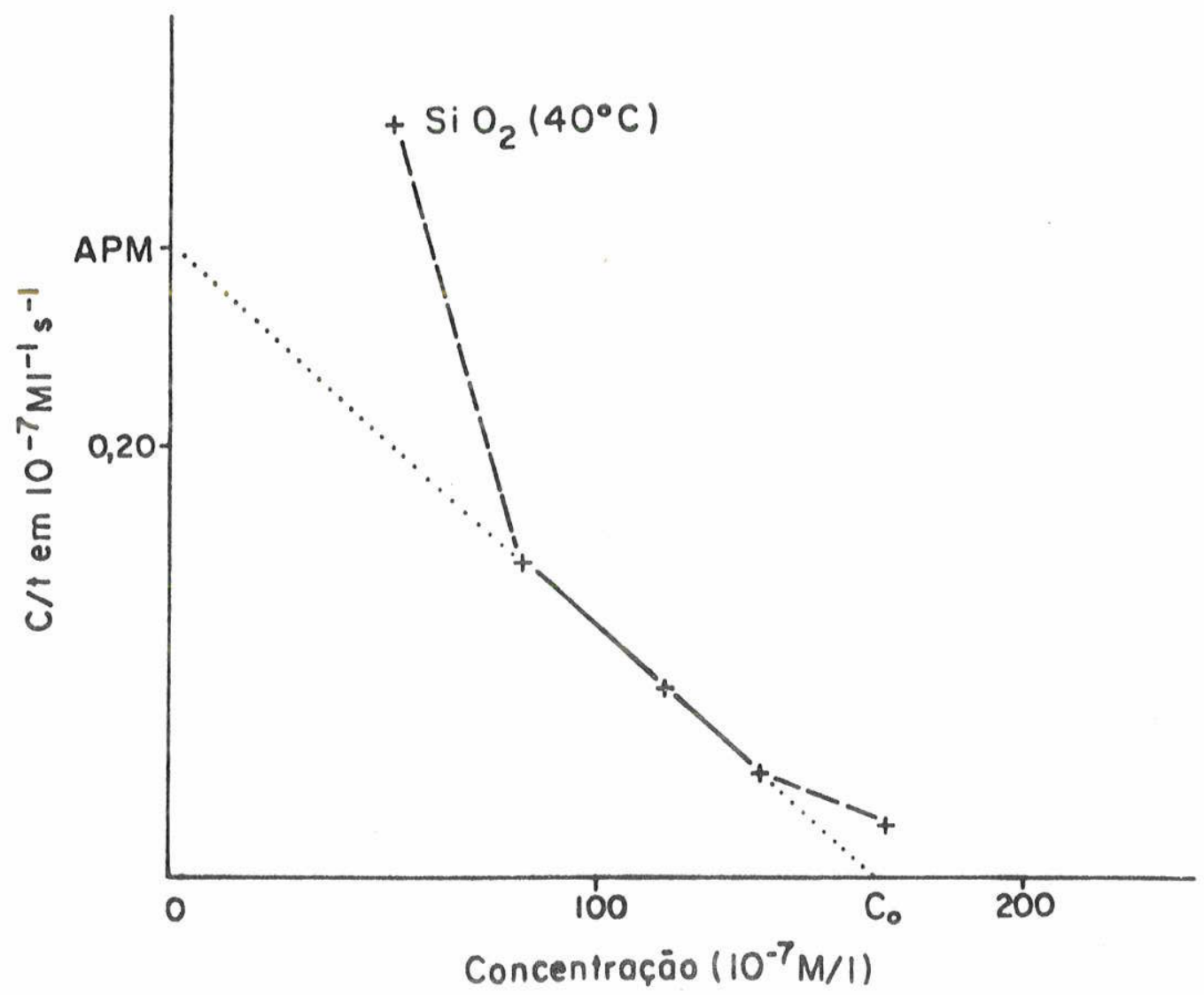

Fig. 2 -DIAGRAMA $C / \uparrow=\uparrow(C)$, DA CONCENTRAÇĀO EM SILICA, A $40^{\circ}$ C. FONTE (A.B.Delmas, 1979.)

um mineral, ou de sua aptidão à alteração, se considerarmos a velocidade máxima de dissolução do mineral em contato com seu solvente puro, numa situação de referência. Esta velocidade máxi ma corresponde, na curva de dissolução (figura 2), ao ponto onde a concentração da solução é nula, e è obtida tambēm por extra polação (A.P.M.).

Pode-se concluir que o conhecimento dos mecanismos de hidrōlise dos silicatos progrediu muito nos ūitimos anos, notadamente graças à utilização sistemática de métodos da físico -quĩmica.

Por outro lado, considerando-se que as variações em termos de pH, Eh, composição mineralögica e orgânica dos 
materiajs no meio de alteração se dão na escala micromētrica, ao nîvel de microssistemas, justifica-se a importāncia que vêm adquirindo os mëtodos pontuais no estudo da alteração (microscopia optica, microscopia eletrōnica, microssonda eletrōnica), importāncia esta demonstrada por pesquisas baseadas tanto em observaçōes efetuadas no meio natural, como em resultados obtidos experimentalmente, que evidenciaram a necessidade de se reconside rar as hipöteses de base utilizadas atē então nos estudos de alteração de rochas e pedogēnese.

Apös uma sērie de trabalhos, tornou-se claro, se gundo Bocquier (1979), que se o sistema geral de evolução durante a alteração intempērica permanece em seu conjunto, aberto e diluĩdo, a alteração se produz, ná realidade, no seio de numerosos microssistemas, mais ou menos independentes, caracteriza dos por uma concentração inicial relativamente elevada em elementos dissolvidos, e submetida a flutuações. Assim, as reações desenvolvidas em tais meios, dificilmente atingem o equilibrio, e, desta forma, a termodināmica convencional das reações de equi lïbrio não se aplica ao que ocorre realmente.

Os minerais primärios iniciam o processo de alte ração a partir das descontinuidades dos cristais e dos contatos entre eles. No inicio, as soluções agentes da alteração percolam lentamente, em espaços de dimensões reduzidas, sendo portanto ex tremamente concentradas, típicas de um ambiente confinante. Estes espaços, ainda pouco abertos, constituem os microssistemas de contato (Proust, 1976, Meunier, 1977). Nestes 1ocais, são frequentemente descritas na literatura, neoformações do tipo mica, como as "micas reacionais" (Ildefonse et al, 1976), mesmo em meios que, quando considerados globalmente, em termos de clima e relevo, sugerem neoformações alïticas ou monossialíticas, mas nun ca bissialiticas. De fato, jā hä algum tempo è reconhecida esta fase bissialïtica transitōria no processo de ferralitização (Segalen, 1957; Caillëre et a1, 1957; Bonifas, 1959; Leneuf, 1959 ; in Chatelin, 1974).

Com a formação do material secundārio, surge o microssistema pläsmico, primārio quando guarda ainda a estrutura do material original, secundārio, se jä houve remobilizaçōes.com 
o correr da alteração, os espaços vazios tornam-se mais abertos, possibilitando uma percolação mais rāpida das soluções, que se tornam diluídas. Nesta fase, temos caracterizado o microssistema fissural. Os microssistemas de alteração evoluem entre si, e sua importância quantitativa varia em cada fácies de alteração.

\subsection{A formação de bauxitas}

Para se discutir a gênese das bauxitas è interes sante utilizar a classificação de Lelong et al (1976), que, embo ra sendo uma classificação morfolōgica, sem dūvida separa diferentes tipos genēticos de depōsitos bauxīticos. Nesta classifica ção diferenciam-se bauxitas laterīticas, cārsticas e sedimentá res.

As primeiras, relacionadas à alteração laterîtica, são formações autōctones, onde o alumīnio é concentrado por enriquecimento relativo, no topo de mantos lateriticos, como le tos concrecionārios ou crostas, com endurecimento variāvel, cobrindo colinas e platôs, oferecendo proteção contra a erosão.Este tipo ē o que nos interessa diretamente, e será discutido deta Thadamente nas prōximas pāginas.

As bauxitas cārsticas em forma de bolisōes, estão associadas a rochas carbonāticas mais ou menos carstificadas, so bre as quais repousam direta ou indiretamente. Sua origem não es tā ainda totalmente compreendida, no entanto, parece que cada vez mais, as investigações indicam uma origem alōctone para a fonte dessas bauxitas, devido às frequentes descobertas de inter calações clāsticas entre o calcārio subjacente e a bauxita (Lelong et al, 1976).

As bauxitas estratificadas inseridas em sēries sedimentares suportam trēs hipōteses para sua gēnese. Podem ser resultado de transporte e deposição de bauxitas laterïticas formadas em outras āreas (Gordon et a 1, 1958; Valeton, 1972), ou de precipitação de alumīnio a partir de soluções formadas em condi ções de pedogēnese ācida (Caillēre e Pobeguin, 1964;Erhart, 1973). A outra possibilidade seria a acumulação de argilas transporta- 
das, com posterior bauxitização "in situ" dessas argilas.

Como parāmetros determinantes das reações de alte ração e das neogêneses nas fases iniciais de alteração, temos, por um lado, a natureza mineralögica, que impõe diretamente tanto as disponibilidades geoquímicas para as dissoluçóes e neofor mações, quanto o pH naquele ponto (Stevens e Carron, 1938), e por outro lado, a estrutura do material, que influencia as condi ções hidrodinâmicas do meio. A interação desses dois fatores explica o que se observa na natureza e em experimentos de laboratō rio (Henin e Pedro, 1971).

Partindo dessas idëias, torna-se compreensīvel que, no inicio da alteração, diferentes minerais primärios, Toca lizados em diferentes sïtios da mesma rocha, e no mesmo contexto morfo-climätico, possam seguir caminhos diferentes no correr da alteração, em termos de transformações e neoformações.

Delvigne (1965), mostrou a alteração diferencial dos minerais primärios; seddoh (1973), as transformações cristaloquimicas na escala do mineral; Trescases (1975) e Wackermann (1975), mostraram a ordem de aparição dos minerais secundārios. Todos esses trabalhos puderam explicar os fatos observados, considerando os horizontes correspondentes aos primeiros estädios da alteração não como meios homogẽneos, mas sim como meios constituidos por microssistemas quase pontuais, praticamente isolados e distintos entre si, caracterizados pela sua mineralogia e estrutura, onde não importam as características mëdias ou globais, mas sim as particulares e pontuais.

São registradas bauxitas em todas as ēpocas geolō gicas onde houve intemperismo em condições propĩcias ao enriquecimento em alumīnio, desde o prë-Cambriano atē o Recente. No decorrer do tempo geológico, teriam existido periodos mais favorāveis à bauxitização (Valeton, 1972; Erhart, 1973). (figura 3).

A ocorrência de depōsitos bauxīticos em locais cu jo clima atual não favorece os processos de enriquecimento em $A \overline{1}$ pode ser explicada atravēs da tectōnica de placas e migração dos 


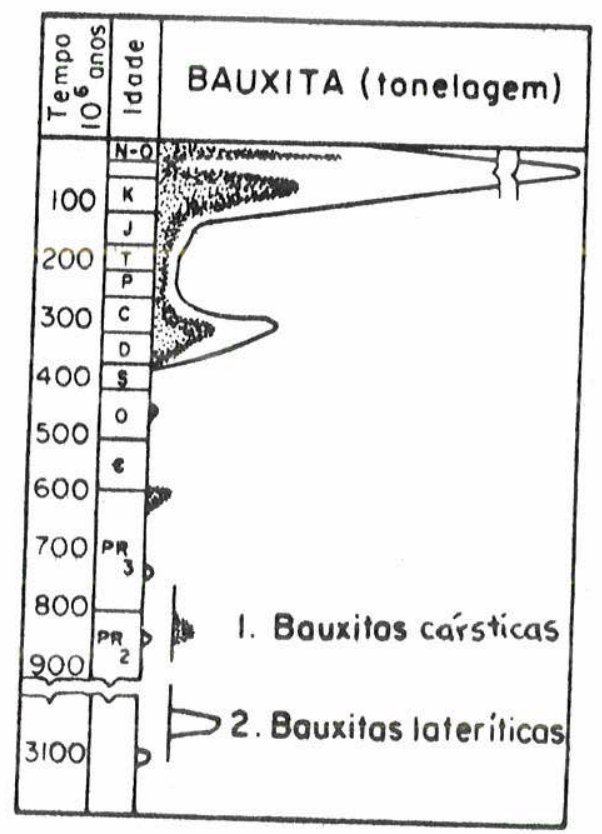

Fig.3 - DISTRIBUIÇÃO DA FORMAÇÃO DE BAUXITAS NO TEMPO GEOLÓGICO. FONTE:

(G. Bardossy, 1973.)

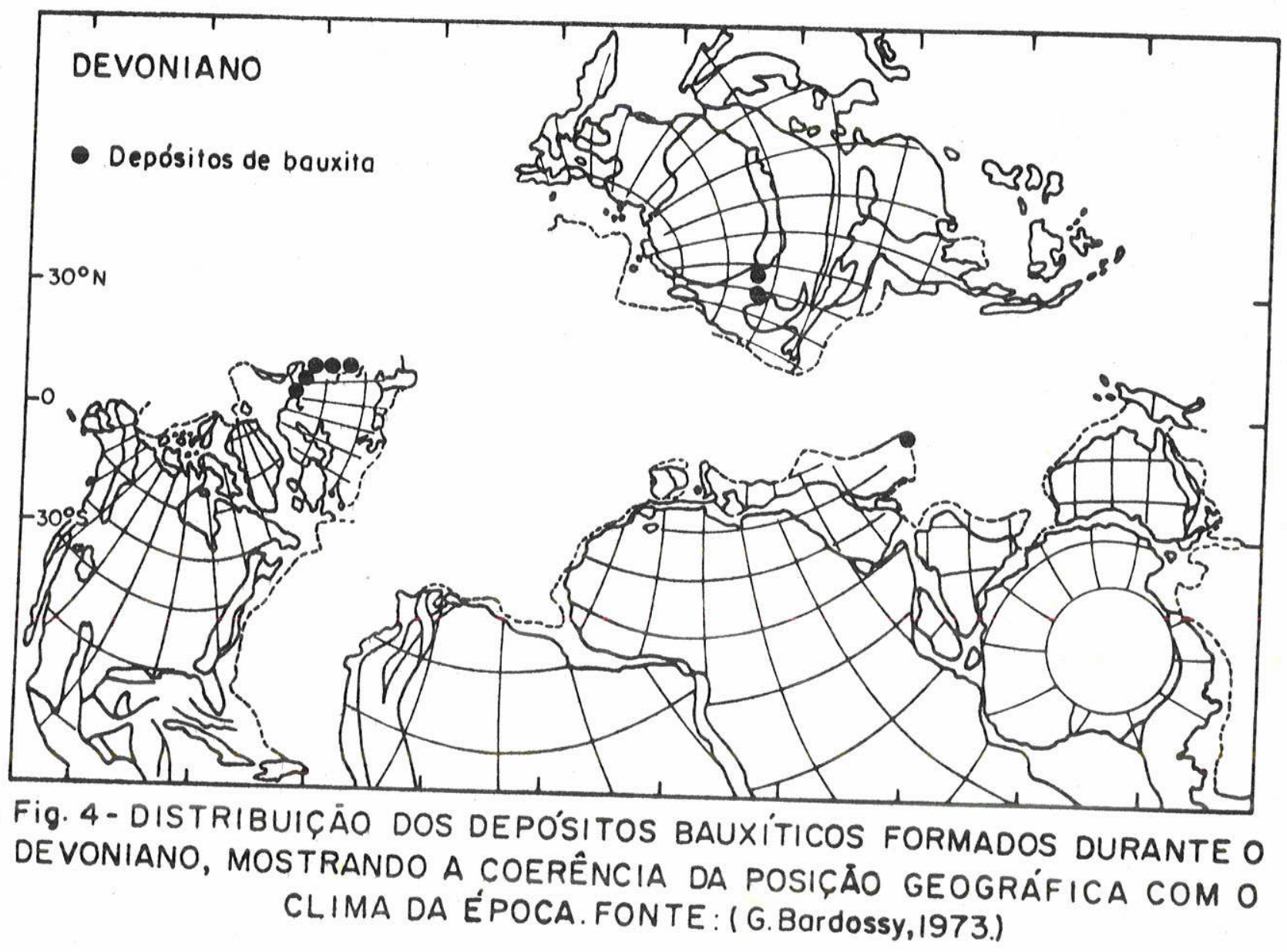


polos. As reconstruções paleogeogräficas indicam uma coerência da posição geográfica na ēpoca de sua formação (Bardossy, 1973 ; Erhart, 1973), como ilustra o mapa da figura 4, apresentando 0 exemplo das bauxitas devonianas.

A distribuição quantitativa cronológico- espacial dos depösitos bauxīticos conhecidos confirmam a tese de Bardossy (1979), de que a intensidade de formação de bauxitas es tá relacionada ao balanço da radiação solar, que é bastante dife rente sobre oceanos e continentes, e varia tambēm segundo a latị tude, devendo ter sido alterado com a deriva dos continentes. Cāa culos do meteorologista Dobosi (segundo Bardossy, 1979), indicam que o balanço global da radiação solar foi mäximo do Devonia no ao Carbonîfero Inferior, e durante o Mesozōico; desde o Eoceno, tem diminuỉdo gradualmente, atē o nīvel atual, não favorāvel à bauxitização intensa, o que jā havia sido notado por outros autores. Erhart (1973), afirma que as bauxitas "quaternārias"são apenas remanejamentos de solos lateriticos mais antigos.

De fato, os grandes depōsitos formados durante - Eoceno, ocorrem em ampla distribuição mundial (figura 5). No Paleozóico, os períodos Pensilvaniano e Mississipiano foram caracterizados por ampla formação de bauxitas.

Possivelmente, uma importância maior deva ser atribuỉda neste sentido ao Devoniano, não obstante as poucas for mações encontradas (Valeton, 1972).

Skinner (1970), encontra na vulnerabilidade aos processos erosivos posteriores à sua formação, a explicação para o fato de que a maioria dos depösitos seja geologicamente recen te, com mais de $90 \%$ de idade pós-Cretācica.

A localização tectōnica dos depōsitos conhecidos, determinada por Bardossy (1973, 1979), evidencia o controle tectōnico na sua formação. A quase totalidade dos depōsitos do tipo laterītico ē encontrada em äreas tectonicamente calmas, ao passo que as bauxitas cārsticas são situadas geralmente nos cinturões orogênicos. 


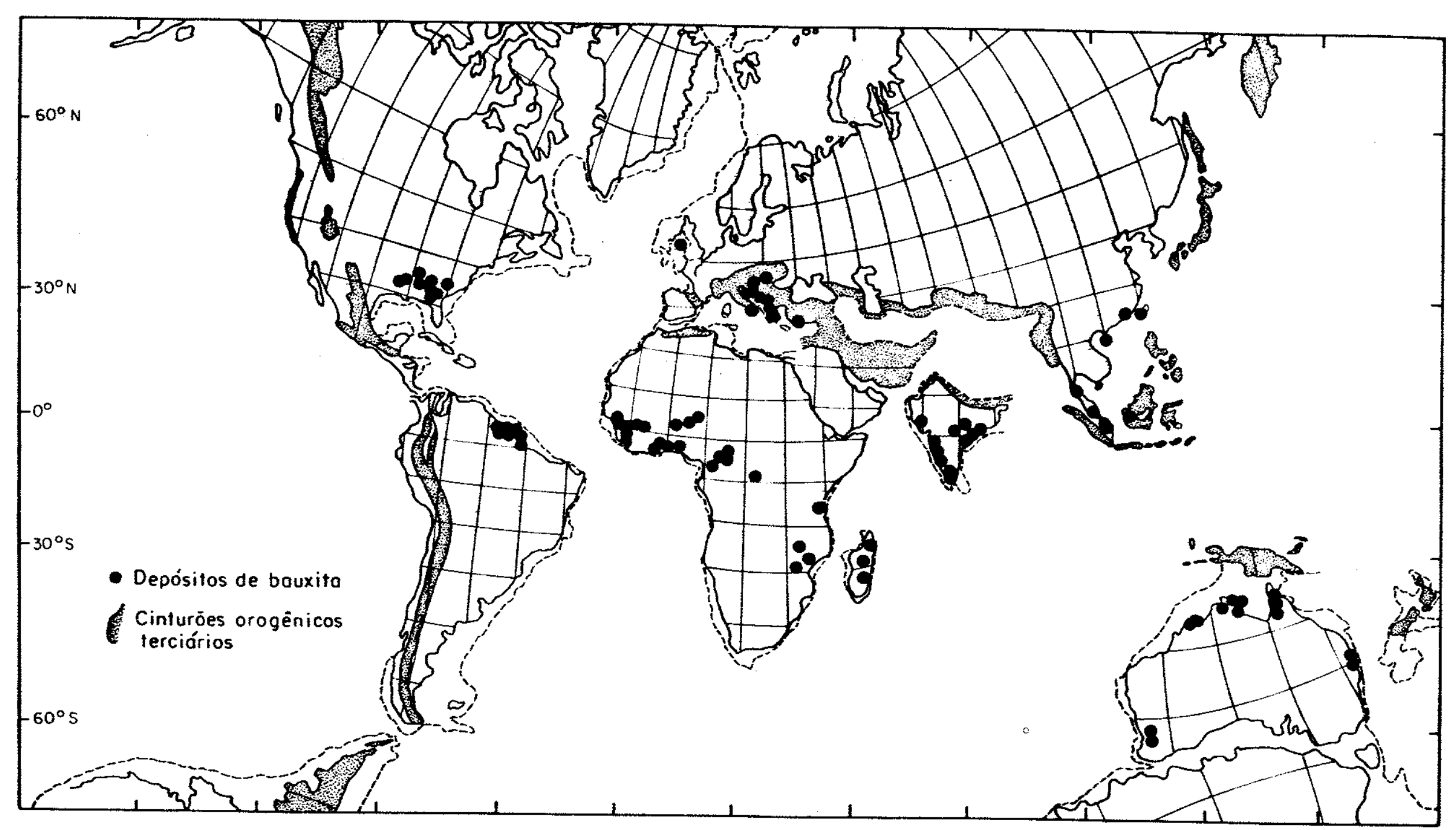

Fig. 5 - DISTRIBUIÇĀO DAS BAUXITAS FORMADAS DURANTE O EOCENO MÉDIO. FONTE:

(G. Bardossy, 1981.) 
Bauxitas Bauxitas Bauxitas

Laterïticas (85\%) Cärsticas (14\%) Sedimentares (1\%)

$\begin{array}{lrcc}\text { Plataformas Continentais } & 96 \% & 8 \% & 100 \% \\ \text { Cinturões Orogēnicos } & 3 \% & 92 \% & - \\ \text { Placas Oceānicas } & 1 \% & - & -\end{array}$

Segundo Erhart (1973), todos os autores concordam, em princīpio, que estā na alteração pedogenētica de rochas sülicoaluminosas, a origem dos hidröxidos de $A 1$, que representam, sem dūvida, a fase residual da laterização, onde temos a eliminação dos alcalinos e alcalino-terrosos, e da maior parte da sîlica dos siticatos.

Lelong et al (1976), resumem o problema da acumula ção residual de hidrōxidos de aluminio a dois aspectos fundamentais. Primeiro, a hidrolização dos minerais primärios, e segundo,a eliminação total dos elementos indesejäveis (bases, sïlica e fer rol. Värios controles condicionam estes processos. 0 volume..das precipitações deve ser suficiente para dissolver os minerais primä rios e individualizar os constituintes quimicos, bem como a drenagem interna dos perfis deve ser suficientemente boa para possibili tar o carreamento dos produtos dissolvidos. Em climas quentes e umidos, em locais relativamente altos e bem drenados, sob uma cobertura vegetal densa, teremos as condições fisicas, químicas e físico-quỉmicas para a formação dos depösitos residuais de bauxita.

Contudo, hä tambëm um controle litolögico, não sō no aspecto mineraiōgico e quĩmico, mas tambēm no aspecto textural-estrutural, que influencia na hidrodināmica.

Em rochas particularmente propicias, pobres em $\mathrm{Fe}$ e em Si, uma vez satisfeitas as condições de clima, relevo e vegetação, teremos facilmente a formação de bauxitas muito puras. Porëm, em rochas ricas em Fe elou em sillica, será necessäria a atuação posterior ou simultānea de mecanismos que os eliminem.

A laterização conduz, em ūitima anālise, a um en- 
riquecimento residual simultāneo em Fe e Al. 0 fato do Fe existir em dois graus de oxidação, com solubilidades diferentes, torna possîvel uma separação entre $\mathrm{Fe}$ e Al em meios redutores, mal aera dos, onde o ferro, reduzido ao estado ferroso, serä eliminado do perfil, pelo menos parcialmente.

$\mathrm{Na}$ presença de ācido carbōnico, tambēm ē possīvel esta dissociação. Lixiviação experimental de värias rochas em ambiente bicarbōnico, moderadamente äcido, mostram que o Fe se torna relativamente solüvel, enquanto $A 1$ permanece imövel (Pedro, 1964 ; Trichet, 1969).

Segundo Norton (1973), para $\mathrm{pH}<4$, Al $\overrightarrow{\mathrm{e}}$ mais solü vel que $\mathrm{Fe}$, desde que o ambiente seja suficientemente oxidante $(E h>0,4)$ quando então haverä uma maior mobilização do Al nas cama das superficiais, ăcidas e bem aeradas, que se depositara $\vec{a}$ mais profundamente ou lateralmente, por pequenos acrēscimos no $\mathrm{pH}$, o que constitui uma outra oportunidade para a dissociação Fe e Al, e formação de camadas preferencialmente aluminosas.

A ação complexante dos ācidos orgänicos tem como efeito alargar a gama de solubilidade do fon em direção a valores de pH mais elevados (Duchaufour, 1968). Assim, haverä a dissocia ção entre Fe e Al tambēm por complexação. Neste caso, em pH atē 5, ē possîvel a complexação do $\mathrm{Fe}^{3+}$ e sua consequente eliminação, eriquanto que nesses meios com pH próximo de 5 , $0 \vec{i}$ on $A 1 \vec{e}$ apenas parcialmente mōvel.

Si e Al tendem a entrar juntos em neoformações de argilominerais, tão logo se encontrem liberados dos edifícios primärios, durante o intemperismo. Contudo, se a drenagem for excepcionalmente intensa, poderä haver a eliminação da sïlica,com neoformação de gibbsita, pois os limites de solubilidade dos mine rais silicāticos não serão necessariamente atingidos, ao contrārio dos meios mal drenados, confinantes em relação à sîlica (Le long et a 1, 1976).

A temperatura tambēm pode influir, segundo cālcu los termodinâmicos feitos por Fritz e Tardy (1973) e Helgeson 
(1969) (apud Lelong et al, 1976), que mostram que em pH äcido,um aumento na temperatura tende a reduzir a solubilidade da gibbsita, e aumentar a da caolinita.

Muito frequentemente, a bauxitização $\vec{e}$ precedida por um estādio intermediārio caolīnico, que evolui para hidrōxidos de Al, ao se dessilicificar, desde que satisfeitas as condições necessärias de temperatura e drenagem.

\section{Areas de Estudo}

As ocorrências bauxīticas selecionadas para este trabalho, localizam-se na região nordeste do estado de São Paulo (figuras 6 e 7), dentro do chamado "Sistema de Rifts da Serra do Mar" (Almeida, 1976), complexo formado pelo conjunto de vales tectónicos, blocos montanhosos e pequenas bacias de origem tectônica. Este sistema representa um dos aspectos mais notäveis em termos topogräficos e estruturais da margem At lānti ca do continente Americano. Os movimentos verticais que ocorreram nesta região desde o Jurāssico, resultaram em desniveis que provavelmente ultrapassaram $11 \mathrm{~km}$, entre as mais altas montanhas e o assoalho da Bacia de Santos.

Esses movimentos originaram as principais feiçöes geolögicas e geomorfolögicas da região, representadas pelas Serras do Mar e da Mantiqueira, e pelas Bacias de Taubaté, São Paulo e Resende, alëm da de Santos. 0 intenso magmatismo correspondente, produziu desde rochas uttrabäsicas e toleiticas, atē granitos perialcalinos. A este magmatismo pertencem as rochas alcalinas do maciço de Passa-Quatro e as rochas bäsicas de curucutu.

0 embasamento prē-cambriano è constituido por rochas da sequência quartzo-feldspätica, principalmente gnajsses, xistos, granitos e migmatitos; aqui incluem-se as rochas produtoras da bauxita de Mogi das Cruzes.

Teodoro knecht iniciou, a partir de 1940, a des- 

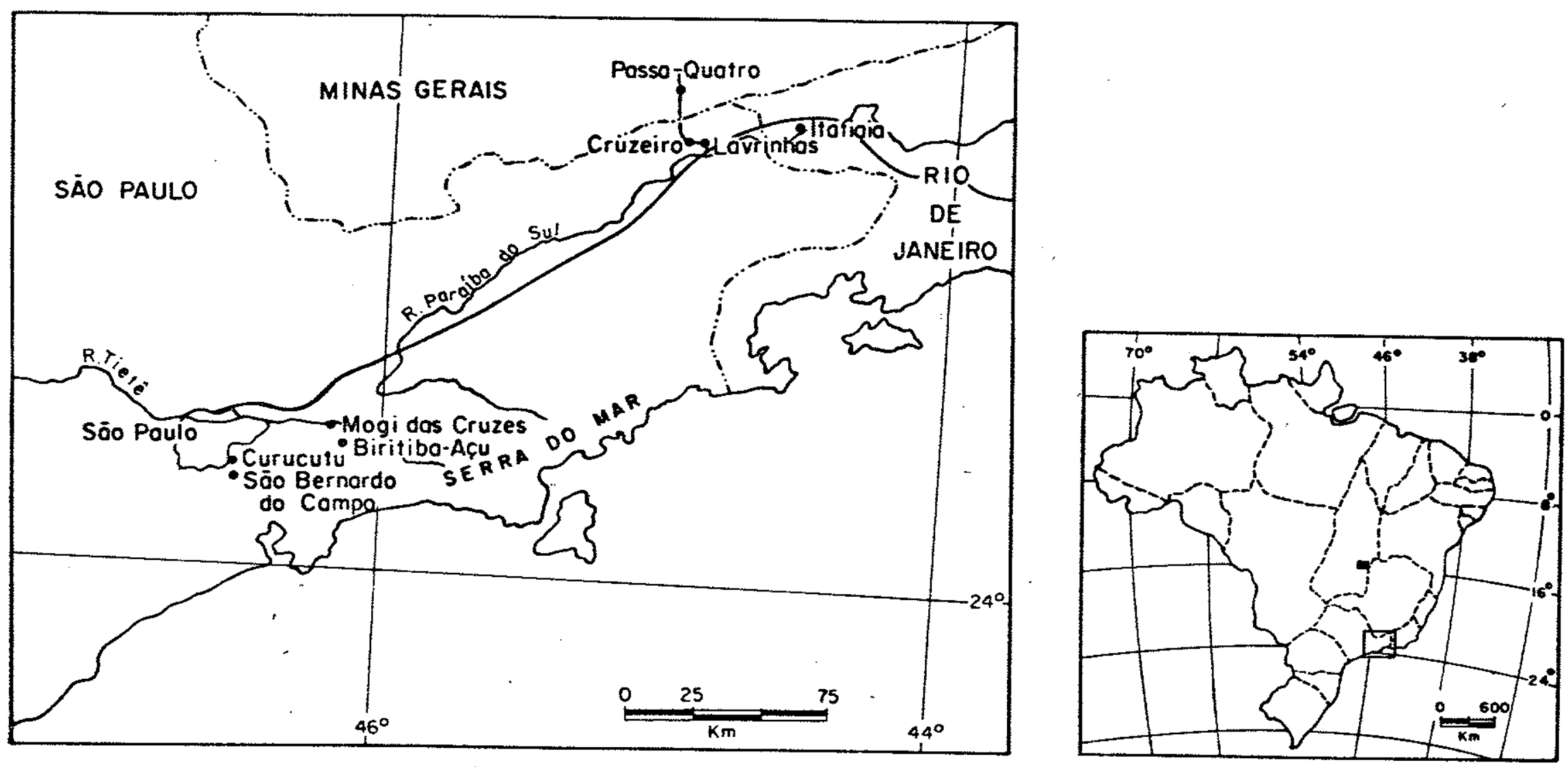

Fig. 6-MAPA DE LOCALIZAÇĀO DAS ÁREAS DE ESTUDO

$\frac{1}{6}$ 

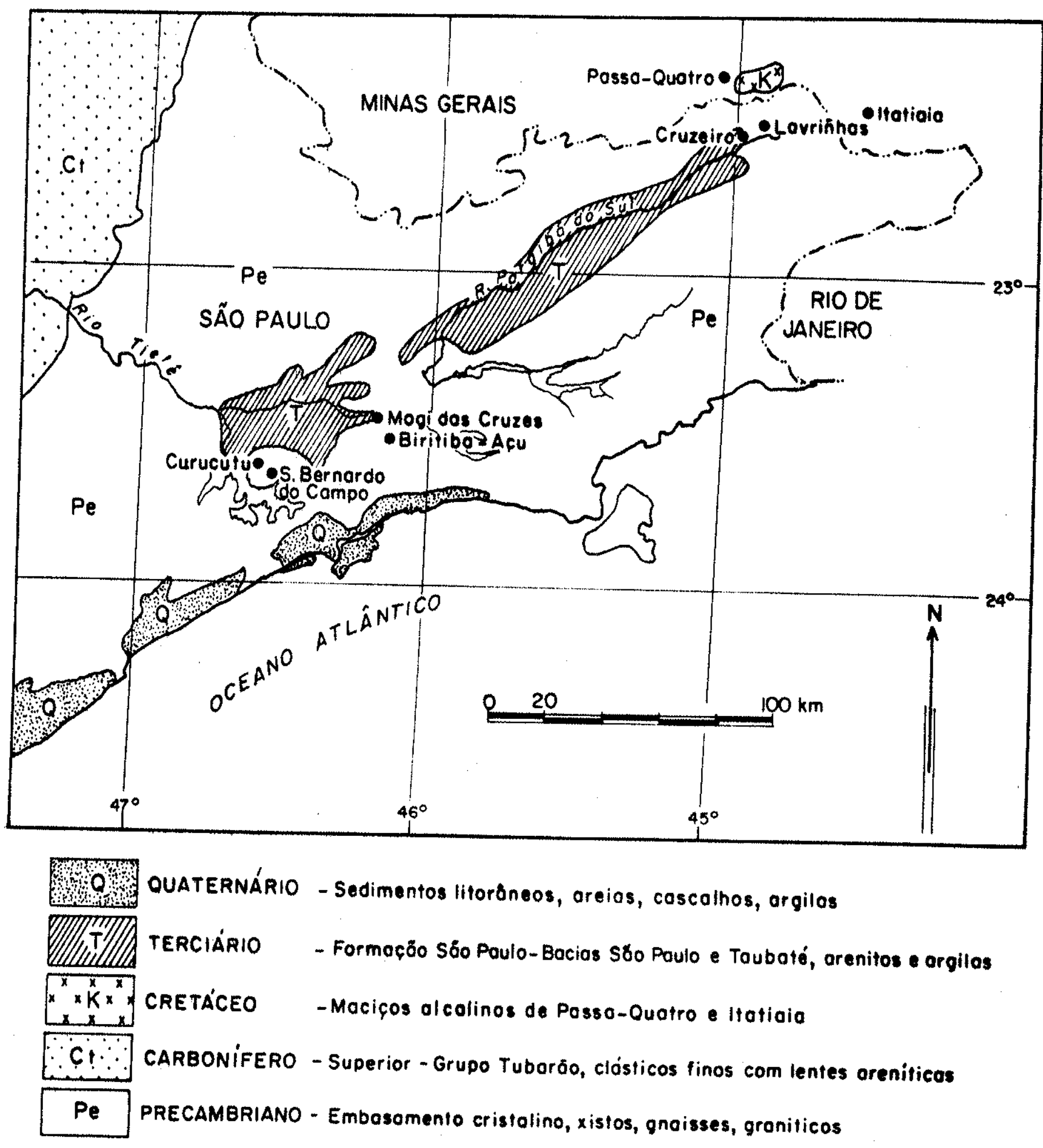

Fig.7-MAPA GEOLÓGICO REGIONAL DO NORDESTE PAULISTA Ref: mopo geol. Estoco de S. Paulo-1GG-1963. 
coberta de inūmeras ocorrēncias de bauxita no nordeste paulista, e Suszczynsky denominou, em 1978, de "Brazilian Atlantic Bauxitic Belt" a faixa que se estende desde os limites da cidade de São Paulo atē o estado do Espīrito Santo, na direção NE-SW,pontị 1 hada pelas ocorrēncias bauxiticas, muitas vezes de reduzida importāncia econōmica, mas sempre de interesse genētico.

\subsection{Mogi das Cruzes}

Esta ocorrência estā situada no bairro de Biritị ba-Açu, municīpio de Mogi das Cruzes. 0 acesso é feito pela estrada que liga Mogi das Cruzes a Taiaçupeba, a cerca de $24 \mathrm{~km}$ do primeiro município.

Os dados climāticos conferem à região o carāter quente e úmido, com inverno seco. A temperatura mēdia anual ē de 180 C, e a pluviosidade atinge $1.400 \mathrm{~mm}$ anuais, irregularmente distribuida. Situada no Planalto Paulistano de Almeida (1964), a ārea possui elevações que chegam a $840 \mathrm{~m}$, apresentando uma uni formidade de altitudes, e desnīveis māximos de 50 a $70 \mathrm{~m}$ (Foto 1). Estas elevações estariam relacionadas a vestígios da superfīcie de erosão Neogēnica de De Martonne (1943-44), que corresponde à superfïcie do Alto Tietê, de Almeida (1958), ou de São Paulo, de Ab'Saber (1958). A localização da ārea coincide com o mapeamento dos resīduos atuais daquela superfície, efetuado por De Martonne (op.cit.) e por Almeida (op.cit.).

0 local estudado constitui uma ārea de topo, e apresenta material não autōctone, mas retrabalhado, fato evidenciado pela presença de fragmentos ou restos de crostas bauxiti cas, não sō no local amostrado, mas tambēm nos topos dos morros prōximos.

Localmente, a geologia da ārea é constituỉda por termos do Grupo São Roque, prē-cambriano, representados por granitos a duas micas, gnaisses e quartzo-xistos.

0 depōsito estudado está rodeado por vārias outras pequenas ocorrências semelhantes e prōximas. 
A literatura especifica sobre esta ocorréncia consta de trabalhos de Guimarães e Kenworthy (1943), Moraes (1943) e Knecht (1952). São todos trabalhos antigos, não havendo publ cações recentes sobre a bauxita da região, que foi a primeira ocorrência bauxîtica derivada de rochas ācidas noticiada no país.

Conforme as obras acima citadas, a bauxita apresenta-se principalmente sob a forma de concreções e nōdulos (foto 2) no manto sobre o granito associado ao Grupo são Roque, e es tā misturada a öxidos e hidrōxidos de ferro e sijiica; ocorrem tambēm depōsitos de argila bauxítica. Via de regra, os depósitos situam-se no lado setentrional e a meia altura das encostas das colinas pouco ingremes, e sempre algumas dezenas de metros acima do nĩvel dos cursos d'ägua. Nas encostas setentrionais não hä abrasão apreciāvel nem pela chuva, nem pelo vento.

Segundo relatörio de pesquisa efetuado por A.F. Barbosa, em 1975, os depōsitos da ārea se apresentam sob a forma de camadas superficiais de cascalho, com nōdulos e blocos de bau xita de diversas texturas e cores, ou em camadas subsuperficiais terrosas, e com teores mëdios em torno de $50 \%$ em $\mathrm{Al}_{2} \mathrm{O}_{3}$, podendo atingir ate $60 \%$. A reserva medida nesta pesquisa foi de 120.000 toneladas de bauxita; associadas a 2,3 milhões de toneladas de caolim e 42.000 toneladas de argilas bauxiticas.

\subsection{Curucutu}

0 local estudado pertence ao Municīpio de São Bernardo do Campo, prōximo à divisa com o município de São Paulo. 0 acesso é feito pela Rodovia dos Imigrantes, atë o km 37 , onde se toma uma estrada secundäria à direita para curucutu.

0 relevo è semelhante ao de Mogi das Cruzes, assim como o clima, com valores equivalentes para a temperatura e pluviosidade. A ärea (foto 3 ) pertence ainda ao planalto Paulistano de Almeida (1964), e suas elevações tambēm corresponderiam a residuos da mesma superfīcie de São Paulo, reconhecida em Mogi das cruzes. As altitudes aqui, pouco ultrapassam os $800 \mathrm{~m}$, e 
mostram um desgaste ou rebaixamento da superfície. A sequēncia amostrada estā em ārea de topo, e corresponde a uma alteração "in situ".

As rochas da ārea são gnaisses e micaxistos, do embasamento prē-cambriano, com intrusões de rochas bāsicas e peg matitos, e tambëm corpos de rochas anfiboliticas, resultantes de antigas intrusivas bäsicas, que sofreram açöes dinamometamörfi cas (Felicissimo e Franco, 1956). No local amostrado, a rocha produtora da bauxita $\bar{e}$ um diabäsio.

A exemplo do que ocorre em Mogi das Cruzes, a ocorrência estudada situa-se em meio a diversas outras semelhan tes nas proximidades. Segundo os autores acima citados, a bauxita ferruginosa forma, via de regra, a crista das rochas bāsicas e anfiboliticas, e é produto autōctone da sua alteração. 0 elüvio da rocha matriz, que geralmente aflora ladeando sua crista, tambëm è constituĩdo de bauxita ferruginosa, que representa o produto final do intemperismo laterïtico, sendo que não hä forma ção intermediāria de caolinita, com transformação direta em ōxi dos hidratados de Fe e de Al.

Gomes (1956), estudou a mesma bauxita de Curututu, considerando-a originada da laterização de um olivina-gabro, que estaria incluido nas intrusivas bäsicas citadas por felicissimo e Franco (op.cit.) e sugere a provāvel importāncia das subs tâncias provenientes da decomposição vegetal no processo de precipitação dos hidrōxidos de alumînio.

Neste mesmo trabalho, Gomes estimou uma reserva provāvel de cerca de 97.500 toneladas de minērio bauxîtico ferru ginoso na ärea de Curucutu, que nunca foi explotado para aluminio. Contudo, jă houve na ärea retirada de material para pavimen tação de estradas. (Foto 4)

\subsection{Lavrinhas}

A região de Lavrinhas, no estado de São Pauto,s $\underline{j}$ 
situada a aproximadamente SW do Maciço Alcalino de Passa- Quatro, recebeu deste maciço material rolado em quantidade, e que sofreu uma bauxitização suficiente para permitir uma exploração econômica das vārias jazidas formadas. 0 acesso é feito pela Rodovia Pre sidente Dutra atē Cruzeirro, de onde parte a estrada secundāria pa ra Lavrinhas.

0 clima é classificado como subtropical, com uma precipitação anual de $1.300 \mathrm{~mm}$, e temperaturas mëdias māxima de 25 C C e mïnima de 140 C.

De acordo com a divisão geomorfológica de Almeida (1964), a ārea estā situada no Médio Vale do Paraỉba, no limite nordeste entre a Bacia de Taubaté e o setor dos Morros cristalinos. As zonas de tālus estão ao pē da Serra da Mantiqueira, e en contram-se jā dissecadas pela drenagem (Foto 5).

Os materiais que ocorrem no tālus e que representam a litologia do maciço são sienitos, nefelina-sienitos e tinguaitos principalmente. As rochas amostradas são nefelina- sienitos e seus produtos de alteração, que ocorrem como blocos de dimen sões variadas, atē 5 metros, imersos em matriz argilosa, de composição gibbsïtica-caolīnitica. Foram estudados dois tipos de nefeli na-sienito, um com textura fina, outro com textura mais grosseira. Ambos apresentaram a mesma mineralogia e evolução durante a alteração, com a diferença de que, para a variedade de textura fina, a transição rocha sã/cōrtex totalmente alterado apresenta-se mais brusca.

0 solo formado sobre o tālus apresenta localmente a formação de nīveis de concrecionārios na base de seu perfil, dan do o aspecto de camada de seixos.

0 embasamento onde se encaixa o maciço, e onde se assenta o tālus, ē constituīdo principalmente por variedades de gnaisses, havendo ainda pequenos afloramentos de quartzito e pegma titos com muscovita e turmalina. 
Associados às rochas alcalinas do Maciço de Passa - Quatro, Sigolo (1979), definiu três tipos de depōsitos bauxîticos: tipo 1, depōsitos residuais sobre rochas alcalinas na forma de tālus, acima de $1.400 \mathrm{~m}$ de altitude; tipo 2, depōsitos residuais sobre rochas do embasamento na forma de tálus, que ocorrem de 800 a $1500 \mathrm{~m}$ de altitude no lado sul do maciço, e de 1.000 a $2.200 \mathrm{~m}$ no lado norte não tectonizado; tipo 3, depōsitos residuais sobre rochas alcalinas, na forma eluvionar, que ocorrem so mente na zona não tectonizada do maciço. 0s dois primeiros tipos são a 1̄̄ctones, e o ūitimo, autōctone ou "in situ".

Os estudos aqui efetuados, restringiram-se ao ma terial dos depōsitos do segundo tipo, que atualmente representa a maior importância econômica na parte sul do Maciço, onde as ja zidas somam uma reserva superior a 1,5 milhão de toneladas (Sigo10, op.cit.) (Fotos 6 e 7). Os depósitos dos tipos 1 e 2,tēm ca racterīsticas que dificultam o seu aproveitamento como a baixa concentração do minērio, com recuperação mēdia de 30\%, a ampla associação com blocos de rocha sã, a espessura muito variāvel da camada mineralizada e a ampla distribuição em ārea. Essas dificul dades são compensadas, entretanto, pela excelente qualidade do mi nêrio obtido, e pela posição geogrāfica privilegiada.

Os depōsitos do tipo 3, no lado norte do maciço: foram descobertos recentemente, e estão sendo objeto de pesqui sa pela Companhia Brasileira de Alumīnio, que jā definiu na ārea reservas superiores a 7 milhões de toneladas de minério com até $16 \mathrm{~m}$ de espessura.

A origem dos depōsitos taludianos ao pē dos Macị ços Alcalinos de Passa-Quatro e Itatiaia estā lìgada à formação e evolução do grāben do Paraĩba do Sul, (Penalva, 1967); contudo o fator climätico deve ter atuado paralelamente (Amador, 1975).

Hā muita evidências de que a formação do tālus 
se deu atravēs de uma movimentação lenta, em meio plāstico, entre elas, a pequena espessura $(1 \mathrm{~m})$ da camada de transição entre o embasamento e o material transportado, com mistura entre ambos, (Sigolo, 1979), e o fato de que o material movimentado não atingiu a Bacia de Taubatē, o que seria de se esperar de um movimento brusco de descida em tal gradiente topogrāfico. Convēm lembrar ainda, que a sedimentação da Bacia de Taubaté atesta o carāter gradual do tectonismo formador do gräben.

Desta forma, o inỉcio da formação do tālus deveria ser colocado no 01 igoceno-Mioceno, época proposta por A 7 meida (1976), para o inīcio da formação do Gráben do Paraỉba do Sul. 0 desenvolvimento do tāius teria progredido com a evolução do grāben, sendo possīvel que ainda não tenha atingido a completa estabilização. Teria havido fases onde o tectonismo foi mais acentuado, e portanto, onde o desenvolvimento do tālus foi menos lento. Estas fases teriam ocorrido durante o Terciārio (Cordani et al, 1974, Melfi et al, 1976), mas hā evidências de reativação dos falhamentos jā no Quaternārio, apōs o fecho da sedimentação da Bacia de Resende, conforme Ab'Saber (1969), o que indica que o desenvolvimento do tälus teria atingido o Quaternārio.

Amador (1975), estudando a estratigrafia da Bacia de Resende, descreveu um membro rudāceo na Formação Resende (Mioceno-Plioceno), constituïdo por material de rochas alcalinas,gros seiro, semelhante ao material do tālus, porém com algumas caracte rísticas que os distinguem, como o caráter "lavado" do membro rudáceo, praticamente sem matriz argilosa. Trata-se, segundo Sigo10, de retrabalhamento do material do tālus, o que colocaria o depōsito como anterior à deposição do membro rudāceo da Formação Resende, isto é, anterior ao Plioceno.

E ainda difícil propor com segurança uma idade para o tālus, considerando que temos um intervalo de tempo possīvel bem amplo, que inclui toda a evolução do Gräben do Paraỉba do Sul, desde provavelmente o 01 igoceno, ate reativações mais recentes, jā no Quaternārio.

A primeira citação da existēncia de bauxita na região do Itatiaia foi mencionada por Pinto (1937), que sugere a 
necessidade de prospeç̧ão na região do Itatiaia e adjacências, on de ocorre fäcil laterização das rochas alcalinas, bem como suá bauxitização, sob condições especiais para o desenvolvimento de tais fenōmenos. 0 mesmo autor, em 1938, diagnosticou sua forma "eluvional" de ocorrēncia, em meio à matriz argilosa. Faz ainda considerações sobre a gênese, que seria consequência de mera late rização ou de quimismo coloidal com laterização em processo.

Outras publicações, como a de Ribeiro Fọ (op. cit.), tratando mais dos aspectos geolögicos e petrolögicos da re gião, fazem alusão às ocorrências de depōsitos de tālus bauxitizá dos, provenientes das rochas alcalinas.

Penalva (1967), estudando a geologia e tectônica do Itatiaia, cita a existência de bauxita em exploração nas imediações de Passa-Quatro, proveniente dos blocos rolados do Maci ço, e faz uma breve descrição da ocorrência.

Sigolo (1979), publicou o trabalho mais recente sobre a geologia de depósitos residuais bauxïticos na região de Lavrinhas-SP, definindo as feições geolögicas principais da ārea e caracterizando os tipos de minērio e de minerais de minērio, os tipos de jazimentos, sua distribuição e fatores controladores, bem como os processos genëticos envolvidos na formação destes jazimen tos.

Entre as conclusões deste ūitimo trabalho, cabe citar as referentes ao processo de bauxitização predominante que, segundo o autor, foi o processo direto, ocorrido principalmente antes da deposição do tālus, e que atualmente ocorre de forma menos relevante ao passo que a bauxitização indireta è restrita atualmente a um certo tipo de depōsito (residual sobre o embasamen to) e que este processo se intensificou apōs a deposição do tā1 us.

Conclui ainda aquele autor, que grande parte do bauxito observado nos jazimentos foi formado em ëpoca anterior à deposição do tālus. o processo que ocorre atualmente não è o gran de responsāvel pela formação dos jazimentos, e sim pela formação do minērio miüdo concrecionärio e remobilizado. A existēncia de 
pequenos seixos de bauxita com caracteristicas das rochas metamōr ficas encaixantes do maciço alcalino, na zona de contato do tāius com as mesmas, traz a conclusão de que o processo de bauxitização mais atuante, antecede à deposição do tālus, pois não hā vestīgios atuais de bauxitização nestas mesmas rochas. 


\section{I. MATERIAIS E METODOS}

1. Materiais

As amostras a serem estudadas, foram coletadas de maneira a se obter sequências de alteração representativas, desde a rocha matriz sã, atē o material bauxitizado, para as ocorrēncias de Curucutu e Lavrinhas, que representam perfis normais, "in situ".

Em Mogi das Cruzes, trata-se de material retrabaThado e antigo, cuja rocha matriz não foi encontrada aflorando nem atravēs de perfurações, devido à grande espessura do manto de alteração. Sua natureza petrogrāfica e mineralōgica foi inferida a partir das evidências apresentadas pelo seu produto de altera ção. As amostras foram coletadas nas paredes de poços, trinchei ras e em cortes de estrada. As fotografias 8 e 9 mostram dois dos perfis amostrados, numa parte onde foi retirado o solo superficial, com a posterior concentração de concreções na superfīcie, vistas com detalhes na foto 2 .

Em Lavrinhas, o material foi amostrado na frente de lavra de uma das jazidas, cujo perfil tīpico está esquematizado na Figura 8. (Foto 10).

Em Curucutu, a bauxita corresponde às cristas do relevo sustentadas por intrusivas bāsicas; a sequência de alteração foi coletada em poços sobre um diabásio.

A figura 8 apresenta um esquema dos perfis tỉpicos das āreas estudadas.

2. Métodos

0s trabalhos de laboratōrio foram organizados segundo o fluxograma a seguir (Fiqura 9) e visaram a caracterização física, quỉmica e mineralógica das amostras, tendo em vista os 


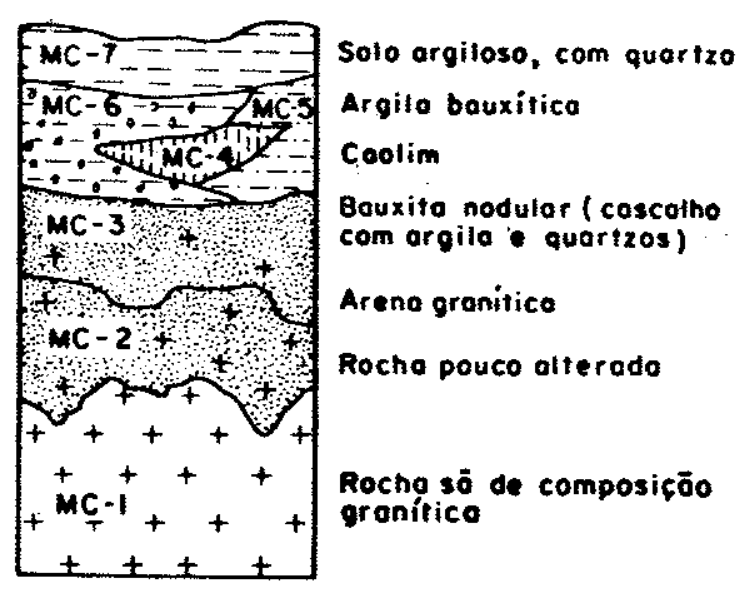

MOGI DAS CRUZES

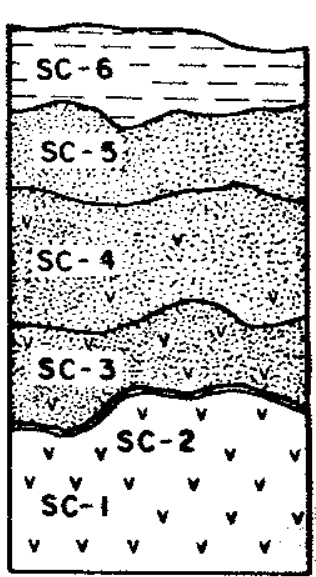

Solo orgiloso

Horizontes superficiais, com das estruturas

Rocha totalmente olterado, com estrutura conservado oporte de moterial

Roche tolalmente alterado. -strutura conservada Cortex

Rocho sö- DIABÁSIO

CURUCUTU

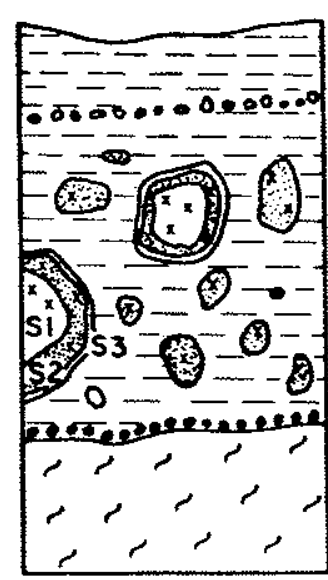

Solo humifero amarelo Nível concrecionório

Matrizargiloso com alto $\mathrm{Al}_{2} \mathrm{O}_{3}$

Blocos de rochas otcolinas $(\mathrm{cm}-\mathrm{m})$ lololmente bouxitilizodos ou com núcleo sōo (nefelina-sienito)

Nivel de seixos alterados quartzo lorecho

\section{Embasomento}

GNAISSE - QUARTZITO

Fig.8-PERFís TIPICOS AMOSTRADOS PARA AS TRES ÁREAS DE ESTUDO. 
Dura

Densidade

Aparente
Amostra

$\begin{array}{lccc}\text { Densidade } & \text { Microscopia } & \text { Anālises } & \text { Separação } \\ \text { Aparente } & \text { Optica } & \text { Quĩmicas } & \text { Granulometrica }\end{array}$

Friāve]

Quĩmicas Granulometrica
$\begin{array}{ll}R-X . & \text { Anālises } \\ \text { Quĩmicas }\end{array}$

FIGURA 9 - FLUXOGRAMA DOS TRABALHOS DE LABORATORIO 
objetivos propostos.

\subsection{Anälise granulomētrica}

A anälise granulomëtrica foi processada a partir de uma aliqquota de cerca de $50 \mathrm{cc}$ de material, obtida por quartea mento da amostra total, seca à temperatura ambiente, desagregada e eliminadas a fração maior que $2 \mathrm{~mm}$ e a matēria orgānica por tratamento com ägua oxigenada.

A argila foi separada por sifonagem da suspensão do material dispersado com pirofosfato de södio. 0 material restante, silte e areias, foi fracionado por peneiramento, a seco.

As frações separadas foram:

- argila: $d<0,002 \mathrm{~mm}$

- silte : $0,002<d<0,053$

- areia fina: $0,053<d<0,210$

- areia mëdia: $0,210<d<0,590$

- areia grossa: $0,590<d<2 \mathrm{~mm}$

As frações obtidas foram analisadas mineralogicamente, por Anälise Termo-Diferencial e Difração de Raios-X.

\subsection{Densidade aparente (D.A.)}

Esta medida foi feita para as amostras com estrutura conservada, para os cāiculos de perdas e ganhos na alteração isovolume. A determinação da densidade aparente é feita em amostras recobertas por parafina, pesadas ao ar e dentro d'ägua, em balança analitica (v.Bonifas e Millot, 1955).

$$
\text { D.A. }=P s / V \cdot A \text {. }
$$

onde

$$
V \cdot A .=\left(P_{T}-P_{2}\right) \cdot D_{a}-P_{p} / D_{p}
$$




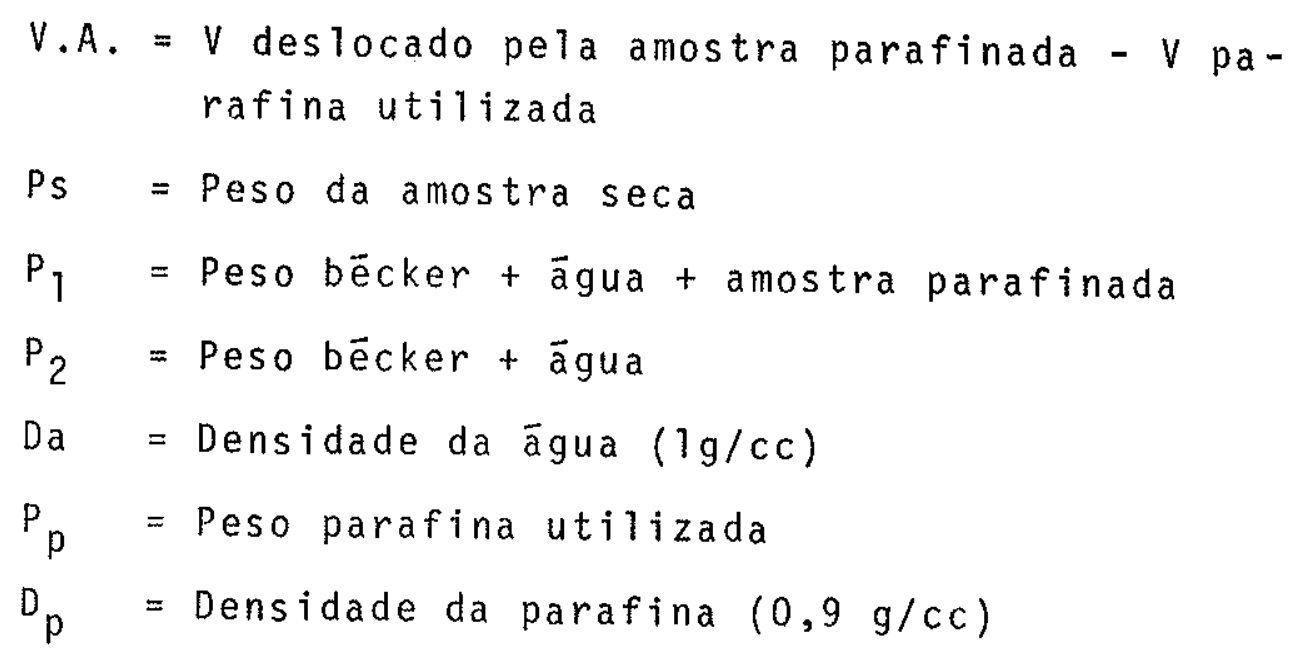

\subsection{Anälise mineralögica por Difração de Raios-X}

A identificação mineralōgica por este mētodo foi empregada tanto para amostras totais como para frações granulomētricas. As amostras totais, e as frações silte e areias foram moi das a 200 mesh; os espēcimes a serem irradiados foram preparados sobre läminas de vidro, a partir da suspensão do material moĩdo em ägua destilada.

Para a fração argila, os espēcimes foram preparados atravēs do espalhamento do material ümido, com espätula,sobre a lâmina de vidro; consequentemente, o material adquiriu uma orientação preferencial das partỉculas argilosas.

0 aparetho utilizado foi um difratómetro de marca Rigaku Denki, modelo de 1976, e as condições instrumentais foram as seguintes:

- velocidade do scanning: $2^{\circ} / \mathrm{min}$ e $1^{\circ} / \mathrm{min}$

- time constant: 1 sec e 2 sec

- CPS: 1000 e 2000

- voltagem: $35 \mathrm{kV}$

- corrente: $15 \mathrm{~mA}$

- velocidade do papel: $10 \mathrm{~mm} / \mathrm{min}$ e $5 \mathrm{~mm} / \mathrm{min}$ 
2.4. Identificação mineralōgica por Anälise Térmica Diferencial

Esta tēcnica de anālise mineralōgica foi emprega da tambëm para amostras totais e frações granulométricas. Em todos os casos, o material foi seco e moído a 200 mesh, e compactado em recipiente prōprio.

0 aparelho utilizado foi de marca Rigaku, e as condições instrumentais foram:

- velocidade de aquecimento: $10^{\circ} \mathrm{C} / \mathrm{min}$

- velocidade do papel: $5 \mathrm{~mm} / \mathrm{min}$

- voltagem: $50 \mathrm{mV}$.

\subsection{Anāitise micromorfolōgica}

As amostras de rocha sã e outras muito duras foram laminadas convencionalmente, na Secção de Laminação do Instituto de Geociências. As amostras friāveis sofreram um processo prēvio de impregnação lenta, a vācuo, com resina sintētica Polilyte, pré-acelerada e dissolvida em monōmero de estireno, adicionada de um catalisador de cobalto para acelerar o endurecimento resultante da polimerização da resina. Este processo de endurecimento possibilita a confecção de lâminas delgadas sem prejuỉzo das estruturas (Verbecke, 1969).

Para a obtenção de slides e fotografias das 1âminas delgadas foi utilizado um Fotomicroscōpico Zeiss.

No estudo micromorfoiōgico, foi empregada a termi nologia adotada inicialmente por Brewer (1964), modificada por Bisdom (1967) e Boulet (1974). Na aplicação desta terminologia, criada a princīpio especificamente para solos, em amostras de rocha alterada, surgem algumas dificuldades relacionadas à classif $\underline{i}$ cação da gibbsita como constituinte do plasma ou do esqueleto.

Da maneira como ocorre, isto è, identificāvel op- 
ticamente, e de diāmetro maior que $2 \mu$, a gibbsita não se enquadra na definição de constituinte do plasma, dada por (1974).

Boulet

Por outro lado, este mesmo autor inclui apenas os minerais primärios na definição de esqueleto. outra definição de esqueleto, dada por Brewer (1964), tambëm exclui a gibbsita aqui considerada, pois, não obstante a condição de tamanho seja satisfeita - maior que $2 \mu$ - os grãos individuais devem ser rela tivamente estäveis, e não facilmente deslocados, concentrados ou remanejados por processos de pedogênese, condição esta que parece näo ser satisfeita pela gibbsita, que sofre muitas vezes remo bilizações mesmo em estāgios de alteração anteriores à pedogênese.

0 meio onde ocorre a alteração $\bar{e}$ o fundo matricial, composto de plasma, esqueleto e vazios. Não hä düvida de que a gibbsita $\bar{e}$ um componente deste fundo matricial; desta forma, parece conveniente utilizar a expressão matriz gibbsïtica pa ra denominar as regiões constituidas por gibbsita nas amostras, identificāvel opticamente e de diāmetro superior a $2 \mu$.

Por outro 1ado, a origem da gibbsita è semelhante à da caolinita, ou seja, ambas são produtos formados a partir dos elementos liberados na hidrōlise dos silicatos primärios, e assim, visto esta semelhança genētica, parece igualmente aceitavel utilizar tambëm a expressão plasma gibbsîtico, por analogia genëtica a plasma caolinitico. Alëm disso, existem certos materiais pedolögicos, como reconhecido por Eswaran et al (1977), entre outros, que apresentam gibbsita na dimensão de silte, disseminada na fração argilosa,e constituindo um caso onde necessaria mente a gibbsita $\overline{\mathrm{e}}$ um dos componentes do plasma.

Foram utilizadas ainda a classificação e termino logia propostas por stoops et al (1979), para descrição das caracteristicas morfologicas dos grãos minerais intemperizados. 
2.6. Anāitises Quîmicas

$$
\text { 2.6.a - Dosagem de } \mathrm{H}_{2} \mathrm{O}
$$

As amostras, previamente pulverizadas e secas em estufa a $1050 \mathrm{C}$, foram levadas à mufla, em cadinhos de porcelana, para calcinação a 10000 C, durante 1 hora. 0s resultados foram calculados pela perda de massa durante a calcinação (Perda ao Fo go), representam o teor em $\mathrm{H}_{2}{ }$, e constam da tabela 1 .

\section{6.b - Dosagem de sitica}

A silica total foi dosada por gravimetria, apōs fusão alcalina da amostra. Os resultados constam da tabela 1.

$$
\text { 2.6.c - Dosagem de cẩcio }
$$

o cälcio foi dosado por titulometria, atravēs da complexação com EDTA, segundo o mëtodo descrito por Pelloux et al $(1971)$. Os resultados, expressos em porcentagem do öxido $(\mathrm{CaO})$, constam da tabela $\mathrm{T}$.

\section{6.d - Dosagem dos elementos maiores}

Para esses elementos com excessão do Ca e Ti, foi utilizado o mëtodo da Espectrofotometria de Absorção Atōmica. A aber tura das amostras foi feita com äcido fluoridico e perclōrico, muito usados neste tipo de anälise. As amostras foram colocadas dentro da faixa de detecção ideal para o aparelho utilizado, por diluições sucessivas. Usou-se um espectrofotōmetro de absorção atomica Varian Techtron, modelo 1250 e os elementos dosados foram $\mathrm{Al}, \mathrm{Fe}, \mathrm{Na}, \mathrm{K}$ e $\mathrm{Mg}$.

Foram preparadas soluções padrão que abrangessem toda a gama possivel de teores das amostras, e construidas as curvas de trabalho, onde foram plotadas as leituras das amostras e convertidos os resultados para porcentagem do öxido, conforme consta na tabela 1 . 
A dosagem do Ti necessitou a utilização da Espectrografia de Emissão, usando-se um espectrögrafo marca Baird-Ato mic. A preparação das amostras constou de moagem do material em intima mistura com grafite e metaborato de litio (fundente), na proporção de $50 \mathrm{mg}$ de amostra para $25 \mathrm{mg}$ de grafite e $5 \mathrm{mg}$ de metaborato de lïtio. A mistura foi submetida a volatização em eletrodo de grafite.

os filmes obtidos foram lidos num densitōmetro marca ARL; as leituras foram plotadas na escala de seidel e comparadas com as curvas de calibração do aparelho, resultando nos dados constantes da tabela $1\left(\mathrm{TiO}_{2}\right)$.

\section{6.e - Dosagem dos elementos menores e traços}

Por conveniência dos mëtodos, Mn, Cu, Co e $\mathrm{Ni}$ foram dosados por Espectrofotometria de Absorção Atōmica, e Ga por Espectrografia de Emissão. Os resultados compõem a tabela 2 .

Outros elementos como $\mathrm{V}, \mathrm{Cr}, \mathrm{Co}, \mathrm{Ni}, \mathrm{Cu}, \mathrm{Zn}, \mathrm{Zr}$ e $\mathrm{Pb}$ foram pesquisados por Espectrografia de Emissão, apresentan do-se praticamente ausentes nos materiais. 
III. RESULTADOS E DISCUSSÕES

1. Evolução Mineralōgica e Micromorfolögica dos Materiais 1.1. Rochas de composição granïtica, Mogi das Cruzes

Rocha Sã

0 material original dos perfis bauxïticos analisados, identificado atravēs de evidēncias apresentadas por amostras mais alteradas, ē uma rocha de composição granitica, de granulação mēdia, constituĩda predominantemente por feldspato potāssico, plagiocläsio, quartzo, muscovita e sericita. A concentração desses minerais, bem como sua distribuição ē muito heterogēnea. Bandas xistosas, bem orientadas, se intercalam a porções graniticas.

Os feldspatos (potässicos e plagiocläsios), são os minerais predominantes, distribuidos por toda a rocha.

A muscovita, cujos cristais apresentam tamanhos entre $100 \mu$ e $1 \mathrm{~mm}$, encontra-se irregularmente distribuida pela rocha, evidenciando a heterogeneidade jā citada. Apare ce concentrada em faixas, o que confere uma certa orientação a certas regiões da rocha.

A biotita, com as mesmas dimensões da muscovita, $\bar{e}$ bem mais restrita, aparecendo em geral em aglomerados.

o outro mineral micäceo presente, a sericita, encontra-se sempre associada aos feldspatos, onde forma pequenas inclusões, dispostas ao longo dos planos de clivagem. e dos limites entre as maclas do mineral hospedeiro. Sua gênese estä associada aos processos metamörficos que afetaram as rochas graniticas originais.

0 quartzo apresenta tamanhos variäveis, ao re- 
dor de algumas centenas de micra, e encontra- se irregularmente distribuido.

Rocha Parcialmente Alterada

Neste horizonte, $\vec{e}$ caracterizado o inicio da alteração de um certo nümero de minerais. A rocha apresenta-se ain da compacta, porēm com maior porosidade e menor densidade aparen te.

os feldspatos estão jä em avançado estado de decomposição (fotomicrografia 1). São os primeiros minerais a se rem atacados pelo intemperismo, que inicia sua ação modificando progressivamente o retīculo cristalino e as propriedades ōpticas, destruindo os limites entre as maclas e a geminação, atē seu total desaparecimento.

A progressão da alteração dos feldspatos conduz, com rarissimas excessões, ä gibbsitização direta, que se instala nos contatos intercristais, clivagens, fissuras e demais deconti nuidades dos minerais, segundo o padrão de alteração linear irré gular ou linear cruzado (Stoops et a1, 1979), caracterizado pela formação de cristais de gibbsita, em geral de grande tamanho e perpendiculares às paredes das descontinuidades. Nestas superfícies, jā hà uma certa ferruginização, que marca a parte central dos canais, proveniente da desestabilização das biotitas.

A muscovita, jă neste fācies exibe as primeiras transformações causadas pelo intemperismo e caracterizadas pelo abaixamento da birrefringência, perturbações nas propriedades ōp ticas e aparecimento da extinção ondulante. Frequentemente, observa-se separação e deformação das lamelas, abrindo espaços que são ocupados por material secundärio ou permanecem vazios (fotomicrografia 2). A percolação por estes espaços provoca em geral a caolinização da muscovita, segundo o padrão linear paralelo (Stoops et al, op.cit.). Esta caolinita assim formada ē, em geral, concordante com a orientação micäcea.

0 primeiro sinal de alteração da biotita $\bar{e}$ evi- 
denciado pela segregação do ferro do retīculo cristalino e sua fí xação, principalmente como hematita entre as lamelas ou pacotes de lamelas, ou então nas bordas dos cristais (Fotomicrografia 3 ). Este ferro segregado pode tambēm sofrer remobilizações, o que è mais comum em fases mais avançadas da alteração. Assim como as muscovitas, as biotitas evoluem, tambēm, para caolinita, em geral pseudomörfica, através de separação e deformação das lamelas, segundo o mesmo padrão linear paralelo. Em geral, sua alteração não passa deste estādio, sendo muito rara ou inexistente a gibbsitiza ção da biotita.

A sericita e o quartzo apresentam-se praticamente inalterados neste estādio. Os cristais de quartzo, antes justapos tos, encontram-se algo separados, permitindo a penetração e depo sição de materiais secundārios, gibbsīticos e/ou ferruginosos (Fo tomicrografia 2).

Rocha Totalmente Alterada com Estrutura Conservada

Este horizonte, denominado arena, è constituído por um material inconsolidado, friāvel, mas que preserva a estrutura da rocha original. Os constituintes acham-se bem alterados, porém seus produtos secundārios continuam associados aos minerais que thes deram origem. As remobilizações são de importância reduzida; desta forma, neste fäceis o microssistema mais importan te è o plāsmico primārio.

A rede de descontinuidades dos feldspatos, jā gibbsitizadas, isola fragmentos destes minerais, que se desestabi lizam, segundo o padrão de alteração pelicular (Stoops et al, op. cit.), formando gibbsita ou raramente caolinita. A gibbsita assim formada tem em geral tamanho bem menor que aquela formada nos microssistemas de contato e fissural. Aqueles fragmentos de felds patos podem também sofrer lixiviação total, originando vazios, separados entre si pela rede de geodos de gibbsita. (Fotomicrografia 4 ).

Sendo os feldspatos os minerais predominantes, e sua alteração principalmente gibbsîtica, o material intemperizado 
neste fācies, caracteriza-se por um fundo matricial gibbsītico de distribuição generalizada, com esqueleto micáceo, quartzoso, e raramente feldspātico.

A muscovita, muito resistente em meios superficiais, apresenta-se em grande parte inalterada, ou exibindo caoIinização incipiente, que acompanha a orientação ōptica do mine ral micáceo. Esta caolinita pode posteriormente evoluir para gị̄ bsita, enquanto que a transformação direta da muscovita em gibbsita é muito rara (Fotomicrografia 5). A gibbsitização da caolị nita proveniente das muscovitas pode se iniciar mesmo antes da alteração total do mineral primārio. Em geral, os cristais de gibbsita são maiores e se formam perpendicularmente à direção das lamelas, destruindo o pseudomorfismo que havia; menos freqüente è a formação de cristais de gibbsita paralelos à direção das lamelas micāceas.

0 comportamento da sericita durante a alteração é muito semelhante ao da muscovita. Sua estabilidade é muito grande, sendo comuns os cristais inalterados associados ä matriz gibbsîtica. Neste horizonte,são ainda conservadas as orientações das sericitas, ligadas à rede de clivagem e maclas dos antigos feldspatos.

As biotitas se alteram mais rapidamente que os outros minerais micāceos, e neste fäcies de alteração, a intensa lixiviação, associada a condições fỉsico-quỉmicas particula res (pH, concentração, etc) pode provocar a solubilização total da biotita, permanecendo "in situ" apenas um "esqueleto" micāceo ferruginoso, proveniente de exsudação do ferro do retīculo no inîcio da alteração.

Neste horizonte, podem ainda ser encontrados cris tais de biotita inalterados, o que contraria os conceitos clássicos sobre a estabilidade das micas trioctaédricas. Na realidade, são apenas alguns cristais que escapam ao intemperismo, por se encontrarem protegidos pelo ōxido de ferro segregado de seus retīculos, ou por se situarem em sỉtios particulares dos microssis temas, que os preservaram da completa destruição. 
Horizontes Superficiais, sem Conservação das Estruturas

Estes horizontes superficiais apresentam caracteristicas morfolögicas complexas, constituindo-se de uma associação de materiais predominantemente argiloso (argilas aluminosas ou caolim), ou predominantemente gibbsitico (bauxita). As argilas são ricas em gibbsita, hidrōxidos ou ōxidos de ferro e quart zo, e a bauxita ē rica em concreções e nödulos, e tambēm em quart zo, mas com menos minerais de ferro. Em ambos os casos, podemos ter uma variação na coerência do material; a estrutura original da rocha jā foi destruĩda, devido à intensa homogeneização dos processos de intemperismo. A porosidade aumenta, e os canais e fissuras sofrem alargamentos importantes, condicionando uma perco 1 ação mais intensa. Nestes horizontes, o transporte de material em solução e em suspensão auxilia a destruição das estruturas pri mārias, e sua deposição origina os cutanes, nödulos e concreções. Nesta fase, ganha importāncia o sistema pläsmico secundärio.

os cutanes, isto $\vec{e}$, depösitos de material secundä rio nas paredes de poros e fissuras, podem ser argilosos e/ou fer ruginosos elou gibbsiticos. Os argilanes são constituídos por caolinita, cujos cristais exibem tamanhos muito reduzidos, o que impede sua individualização e caracterização nos estudos microscō picos. As feições micromorfolögicas e as propriedades öpticas dos argilanes representam valores estatisticos para as caolinitas. Os ferranes são geralmente constituĩdos por goethita, e devem ser considerados, na sua maioria, como ferriargilanes, pois a goethita encontra-se quase sempre associada a quantidades variāveis de cao linita, o que dificilmente è discernivel ao microscōpio. Oxido de ferro na forma de hematita é encontrado em grānulos, associado ao plasma caolínitico ou em meio à gibbsita. No primeiro caso, o fer ro pode colorir a argila, enquanto que no segundo, estä sempre individualizado.

Neste estādio da alteração, o plasma primärio continua a ser formado, a partir da evolução superficial dos mine rais mais resistentes.

Alguns minerais micāceos parcialmente alterados e quartzo, constituem o esqueleto do material. o quartzo, mesmo nes- 


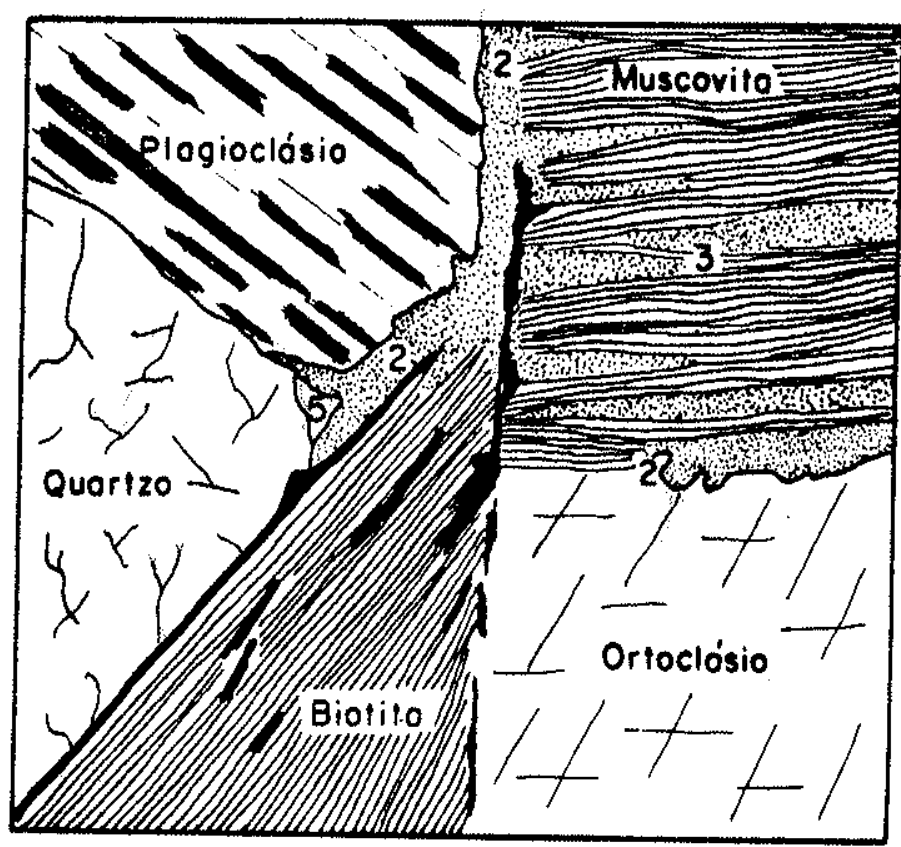

1- Contato neutro

2- Espoços obertos pelo desestabilizaçóo simultôneo dos minerois primórios e ocupodos por material secundório (coolinita, gibbsita, óxidos de ferro).

3- Espaço oberto pela alteraço deformocáo dos lamelas de muscovita, ocupodo por coolinita neoformoda.

4 - Zono de difusão do ferro

5- Vozip resultante do dissoluçóo do quartzo

Fig. 10-ALTERAÇÃO DAS ROCHAS COM QUARTZO 


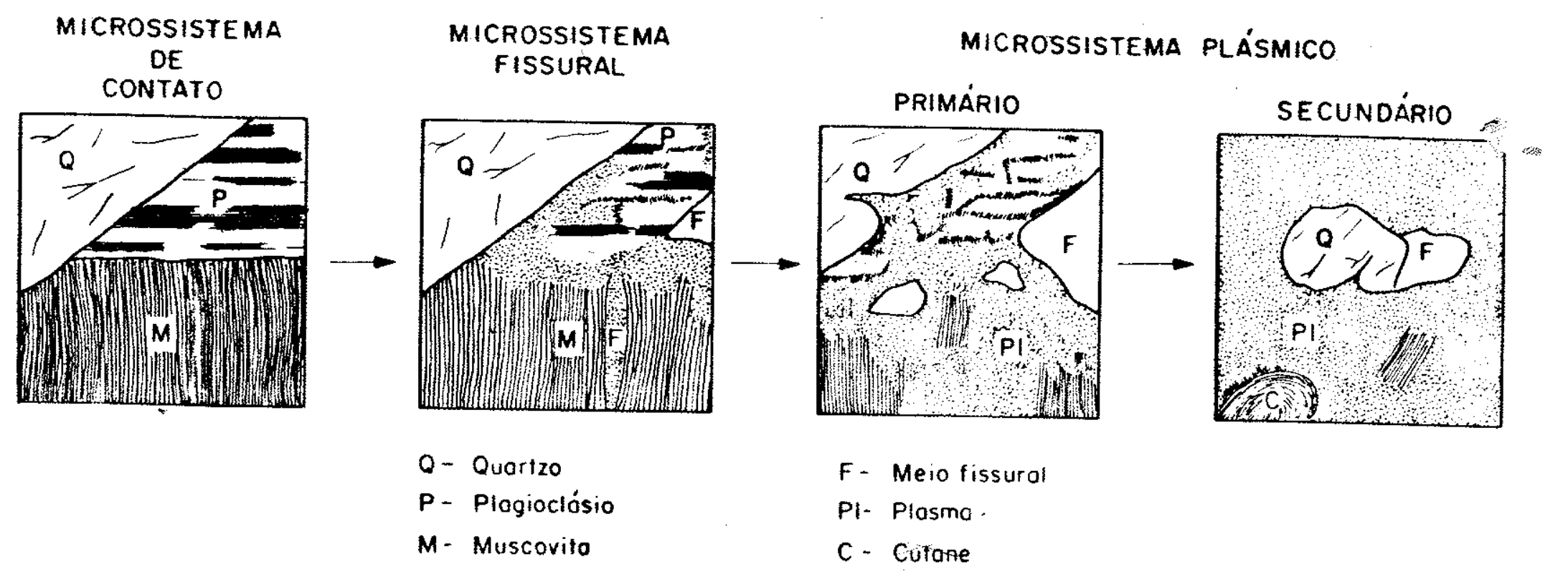

Fig. 11 - EVOLUÇÃO DOS MICROSSISTEMAS DE ALTERAÇĀO NAS ROCHAS COM OUARTZO 
tes horizontes mais superficiais, suporta bem os agentes do intem perismo. Sua evolução e carâcterizada pelo aumento de fragmentos trincados e corroidos, os quais se encontram cimentados por gibbsita elou ferro, que invadem estes espaços vazios provocados fisica ou quimicamente, por tensões ou dissoluções, respectivamente (Fotomicrografias 6 e 7 ).

As figuras 10 e 11 mostram esquematicamente os sïtios de desestabilização dos minerais primārios e de formação dos minerais secundārios, e a evolução dos microssistemas de alte ração no material estudado neste item.

\subsection{Rochas Bāsicas, Curucutu}

\section{a) Rocha s̃̃}

A rocha matriz do perfil bauxitico de curucutu $\overrightarrow{\mathrm{e}}$ um diabāsio, com textura predominantemente of $\overrightarrow{t i c a}$. Os minerais mais abundantes são plagiocläsios (andesina e oligocläsio), piroxênios (diopsĩdio) e anfibōtios(hornblenda). Durante o estudo das lâminas delgadas, foi possivel identificar ainda, em quantidades pequenas, outras espēcies de piroxēnio, como augita, hiperstēnio e enstatita, de anfibölio, como tremolita, e ainda olivina, além de minerais opacos, provavelmente magnetita, e de clorita e bioti ta. Estes $\bar{u} 1$ timos são muito raros, com frequências menores $\because$ que $1 \%$.

A olivina apresenta frequentemente um bordo de reação, geralmente constituĩdo por piroxênio, quando incluĩda em cristais de plagioclāsios; tambēm observa-se modificações nas bor das da olivina incluĩda em piroxênios. Esses bordos de reação serão conservados durante a alteração, como serä visto mais adiante.

b) Cörtex da rocha sã

A transição entre rocha sã e alterada ē brusca; a $1 \mathrm{~cm}$ ou menos do material inalterado, todos os constituintes mine 
rais encontram-se $j \bar{a}$ totalmente alterados, mas conservando a estrutura intacta.

No cörtex, os plagiocläsios foram totalmente gib bsitizados, e esta gibbsitização ocorre sempre a partir das descontinuidades no interior dos cristais e de seus contornos, que săo a sede dos microssistemas de contato existentes no inīcio da alteração, por onde percolam as soluções agentes do intemperismo. Esta rede de descontinuidades, que determina um padrão de altera ção do tipo linear cruzado ou linear irregular, segundo a terminologia de Stoops et al (1979), ē preservada pela gibbsita que nela se forma, e isola fragmentos de plagiocläsios, que são 1ixiviados a partir de sua periferia em direção ao centro. Este tí. po de alteração classifica-se no padrão pelicular, conforme os autores acima citados, e contribui para o aumento da porosidade e diminuição da densidade aparente em relação à rocha sã (Fotomi crografia 8 ).

os piroxēnios e anfibölios, como todos os minerais, iniciam sua alteração pelos microssistemas de contato: representados pelas descontinuidades de clivagens, fissuras e limi tes dos cristais. Hä uma exsudação do ferro do retīculo cristali no em direção ã periferia do cristal ou fragmento de cristal; des ta forma, o ferro serā concentrado como öxido, em geral goethita, nas descontinuidades, resultante numa rede castanho- avermelhada, que denuncia o padrão de clivagens, fraturas e limites dos minerais primärios. Os fragmentos delimitados por essa rede são tambēm lixiviados, constituindo-se este fato em outro fator de aumento de porosidade.

A porosidade assim formada constitui-se no siste ma fissural, por onde circulam mais rapidamente as soluções. Esta percolação, mais livre, rāpida e mais diluĩda, poderā produzir importantes remobilizações no decorrer da alteração, tanto do Fe como do Al.

A olivina se altera formando goethita em todo o espaço ocupado pelo antigo cristal. Essa goethita tem uma cris talização bem mais perfeita que aquela goethita da rede dos ant gos piroxênios e anfibōlios. Esta perfeição pode ser explicada 
- pela pureza do material inicial, sem aluminio, sendo öxido de fer ro puro o resultado de sua alteração. A goethita das relĩquias de olivinas sofre extinção simultânea em todo o cristal ao girarse a platina do microscōpio, o que evidencia a boa cristalização mencionada. Nas fissuras destas reliquias, ocorre magnetita de origem endogena, jă observada na rocha sã.

As coroas ou bordos de reaçäo das olivinas, constituĩdas por piroxênios, sofrem alteração similar à dos cristais de piroxēnios, isto é, resultam numa rede de goethita com padrão idēntico ao dos piroxēnios, distinta da goethita da olivina (Foto micrografias 9 e 10 ).

Neste fäcies foi observada, embora raramente, a ocorrencia de argilominerais de estrutura 2:1, tipo vermiculita, nas bordas de poros, formando geodos ou argilanes.

c) Rocha totalmente alterada, com estrutura conservada

0 material correspondente a este fäcies apresenta se semelhante ao cörtex de alteração da rocha. 0 aspecto geral $\vec{e}$ o mesmo, isto ê, observa-se ao microscōpio, um "esqueleto" gibbsitico, poroso, nos locais antes ocupados por plagiocläsios, e goethitico, igualmente poroso, nos locais de antigos piroxênios e anfibölios. A porosidade è maior no esqueleto goethïtico.

Os microssistemas de contato perderam sua importância na transição rocha sã/rocha alterada, assim que os mine rais primärios se individualizaram, separando-se um dos outros, pela ação das soluções, dissolvendo material primärio e depositan do material neoformado (gibbsita e goethita, essencialmente). Nes ta etapa, o material alterado constitui o sistema pläsmico primärio, onde as orientações originais dos minerais primários são con
servadas.

Subsistem nesta etapa da alteração, as reliquias de olivinas, conforme descrição anterior. 
A vermiculita, neoformada no cörtex, representa a fase bissialītica transitōria da laterização, e neste fäcies jă não existe, tendo sido transformada em gibbsita e ōxidos de ferro, conforme a tendéncia geral da alteração. 0 ferro sofre uma segregação do retĩculo cristalino, posicionando-se de modo a sublinhar a estrutura da antiga vermiculita.

d) Rocha totalmente alterada, com estrutura preservada e aporte de material

Neste fäcies do perfil estudado, as modificações em relação ao fäcies precedente residem na destruição quase completa dos minerais opacos, e na importação de material gibbsitico que, migrando de perfis topograficamente mais elevados, vem preencher tanto os poros do esqueleto de goethita (antigos piroxênios e anfibölios), como do esqueleto de gibbsita (antigos pla giocläsios), formando o plasma secundärio, que não guarda vestị gios do material inicial. Desta forma, estes horizontes sofrem ja um enriquecimento absoluto em aluminio, diminuindo a porosida de e aumentando a densidade aparente (Fotomicrografias 11 e 12 ).

0 padrão de descontinuidades dos ferromagnesianos sublinhado pela rede de goethita, sofre deformações, devido ä cristalização da gibbsita no interior dos esqueletos ferruginosos (Fotomicrografia 13).

e) Horizontes superficiais, totalmente alterados e sem conservação das estruturas

Nestes horizontes, ainda $\bar{e}$ visivel a estrutura primāria em certas regiões das amostras estudadas, mas, de forma geral, aquela estrutura jā foi destruîja pelas remobilizações, principalmente da gibbsita, que sai do esqueleto dos antigos pla giocläsios, destruindo seus vestĩgios, e forma acumulações na forma de geodos ou gibbsanes, com boa cristalização (Fotomicrografia 14). Algumas dessas acumulações de gibbsita são visiveis macroscopicamente, como crostas delgadas, de 1 ou $2 \mathrm{~mm}$ de espessura revestindo as paredes de fissuras (Fotomicrografia 15). 


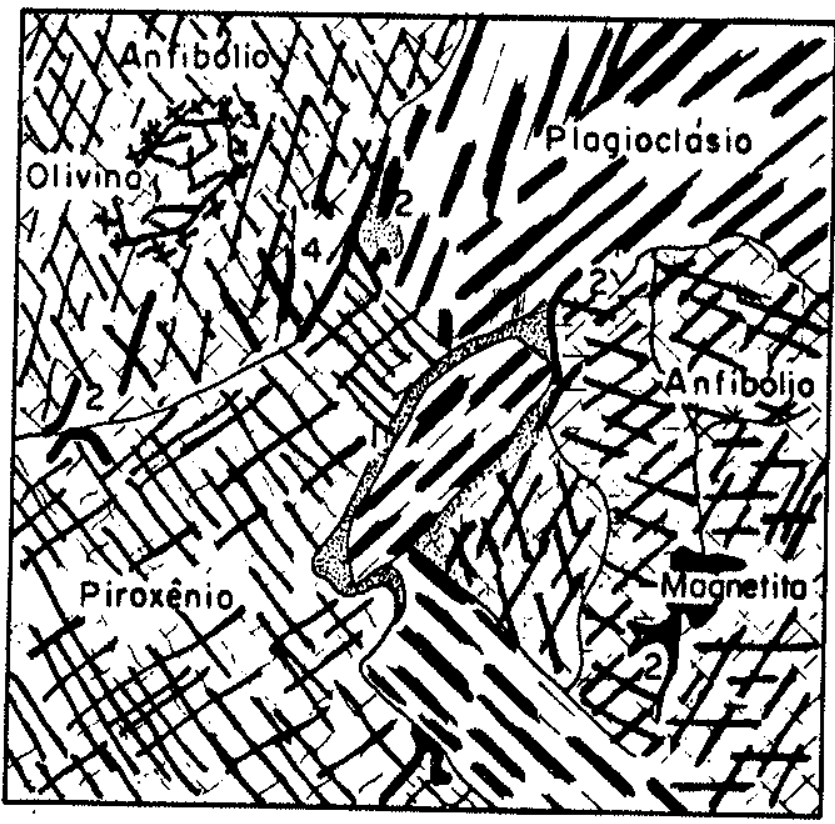

1- Aberfura dos contatos, pelo destabilizacōo dos minerais primarios - formaço de minerais secundórios

2- Zono de difusão de ferro

3-Bordo de reoço (piroxénico) do olivino

4. Vozio resultonte do lixivioço do mineral primário

Fig.12 - ALTERAÇÃO DAS ROCHAS BÁSICAS. 


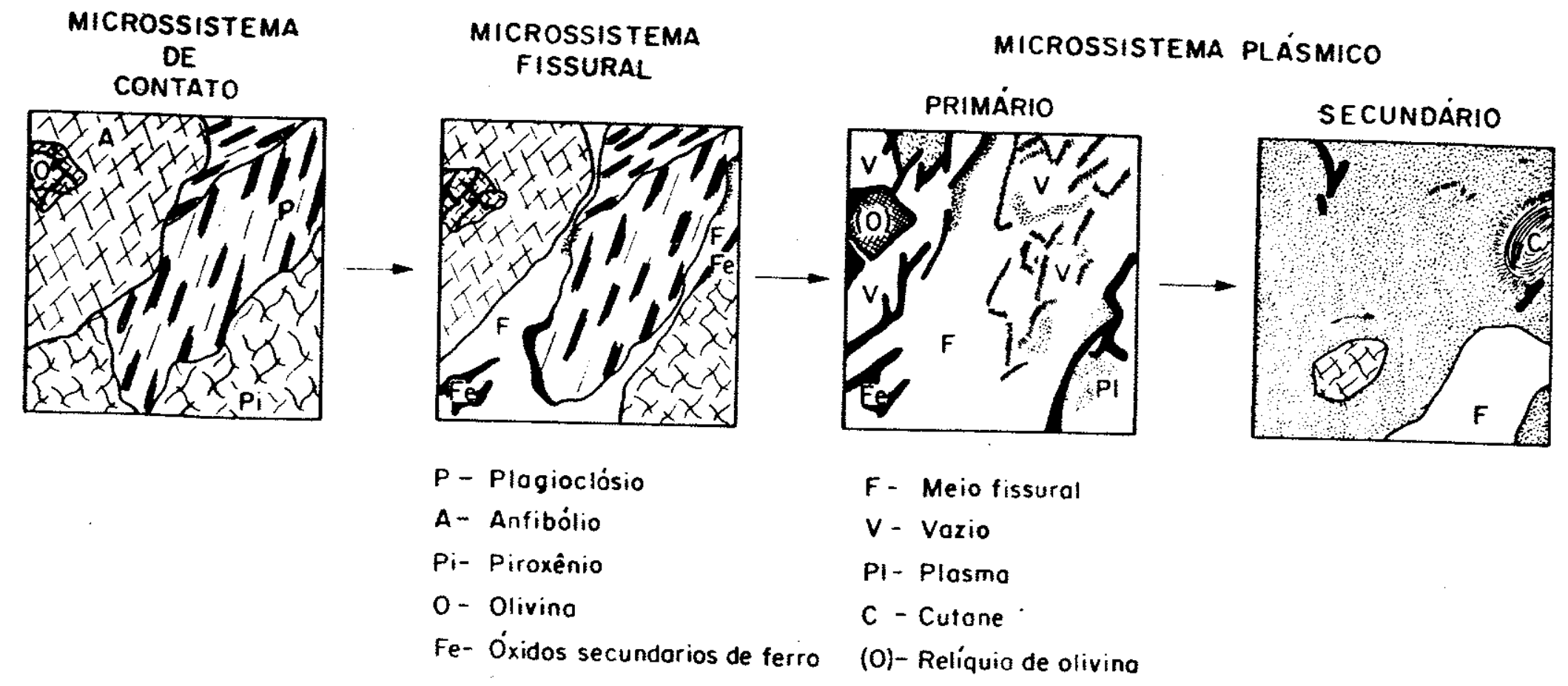

Fig. 13-EVOLUCÃO DOS MICROSSISTEMAS DE ALTERACĀO NAS ROCHAS BÁSICAS 
Em alguns locais ocorre hematita nos poros do esqueleto de goethita, sugerindo uma transformação desta na prime ra, precedida ou não de remobilizações. Ocorrem tambēm ferrigibbsanes, formadas pelo depōsito de ferro (no interior) e gibbsita (nas bordas) em espaços antes vazios. 0 ferro destes depósitos pode ser tanto goethita como hematita.

Permanece ainda boa parte ou mesmo a quase totali dade das reliquias de olivina.

Em algumas partes destes horizontes, $\bar{e}$ nītido o inīcio da remobilização do ōxido de Fe das relīquias dos ferro magnesianos, pela deformação de suas estruturas.

As figuras 12 e 13 sintetizam a alteração das rochas aqui estudadas, evidenciando a presença dos microssistemas de a lteração.

\subsection{Rochas Alcalinas, Lavrinhas}

a) Rocha sã

Os minerais presentes no nefelina-sienito inalterado são principalmente nefelina, leucita, plagioclásios e ortoclāsio; ocorrem como acessōrios, titanita,hornblenda verde e mine rais opacos (magnetita e ilmenita).

Os plagioclásios, principalmente albita, apresentam sempre geminação simples, e inclusões de nefelina e hornblen da. Os cristais de hornblenda podem tambēm ser encontrados inclü sos na leucita ou no contato leucita-plagioclásio. Os opacos podem encontrar-se inclusos em quaisquer dos minerais presentes.

b) Cōrtex da rocha sã

Os feldspatöides são os primeiros minerais a serem atingidos pela alteração, que se instala inicialmente nas 
descontinuidades e contornos dos cristais, constituindo os micros sistemas de contato. Esta alteração resulta numa rede de gibbsita, de alta porosidade, que conserva o traçado das clivagens, fissuras e limites dos cristais, analogamente ao que ocorre aos plagiocläsios das rochas anteriormente estudadas, e tambëm desta.

Os fragmentos de nefelina e de leucita isolados entre si por essa rede de gibbsita neoformada, sofrem dissolução e lixiviação total, ou são transformados em substāncias amorfas silico-aluminosas, que mais tarde podem se cristalizar em gibbsita, ao perder a sijica.

Neste fäcies, ainda existem fragmentos sãos de plagiocläsios, embora raros (Fotomicrografia 16). A grande parte estä ja alterada, tendo como resultado a formação do esqueleto gibbsitico poroso caracteristico (Fotomicrografia 17). E possīvel a distinção entre a rede gibbsïtica proveniente da alteração dos feldspatöides, e a proveniente da alteração dos plagioclāsios, que possuem padrões diferentes de descontinuidades (Fotomicrografia 18).

A hornblenda $\vec{e}$ alterada deixando um resĩduo ferru ginoso, que pode ser tanto de hematita como de goethita. Observou se a presença de vermiculita, como uma primeira fase na transformação da hornblenda, ocorrida na periferia do cristal. Apōs essa vermiculitização, o interior do cristal è alterado, resultando num residuo de öxidos de ferro; em seguida, a vermiculita, sendo apenas uma fase transitōria, ē tambēm alterada em öxidos de ferro.

c) Rocha totalmente alterada, com estrutura conservada

Neste fäcies, estão totalmente alterados os felds patōides e plagiocläsios, resultando num esqueleto gibbsïtico, é os anfibólios, resultando num esqueleto ferruginoso, principalmen te hematitico. No caso em que o resíduo da alteração da hornblenda $\bar{e}$ constituĩdo por goethita, hä melhor conservação de sua estru tura. 


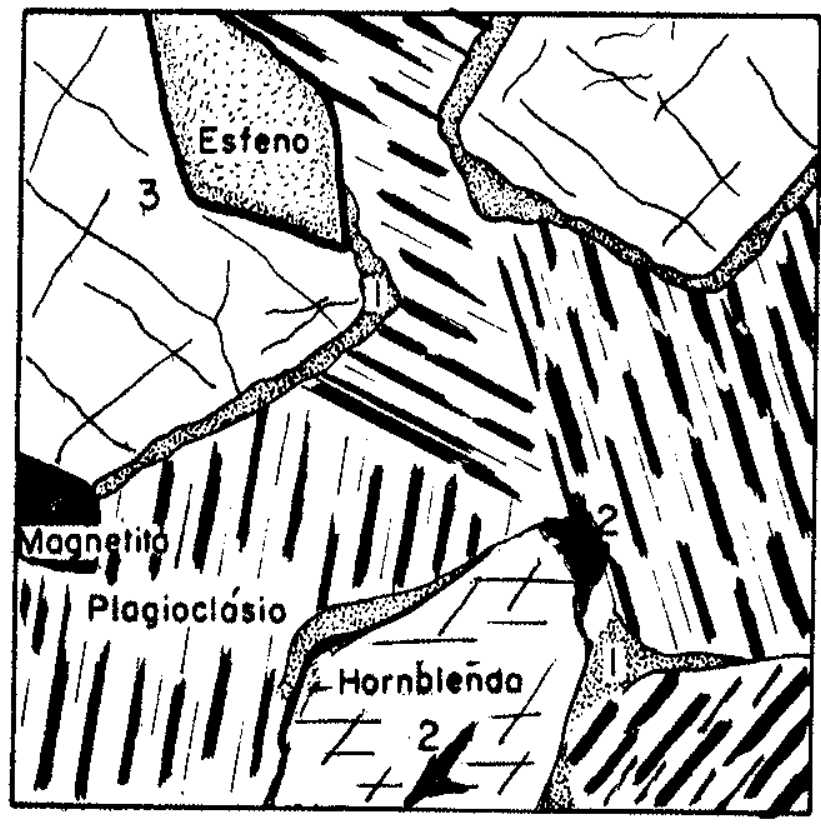

1- Espocos obertos pela desestabilizaçõo simultónea dos minerois primórios, ocupados por moterial secundório

2. Zona de difusōo de ferro

3. Contoto neutro

Fig. 14 - ALTERAÇAO DAS ROCHAS ALCALINAS 


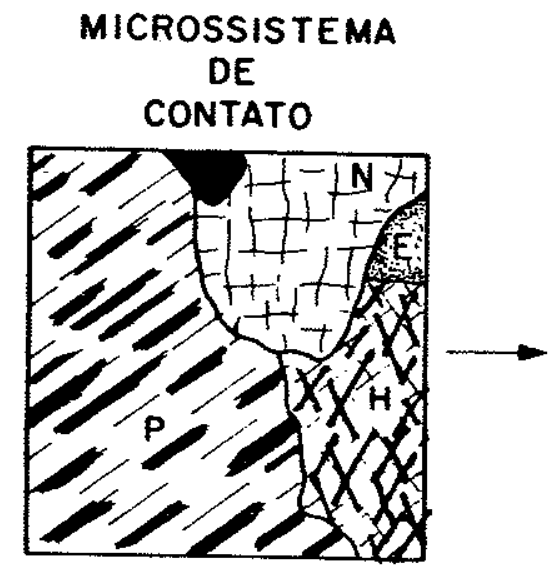

MICROSSISTEMA FISSURAL

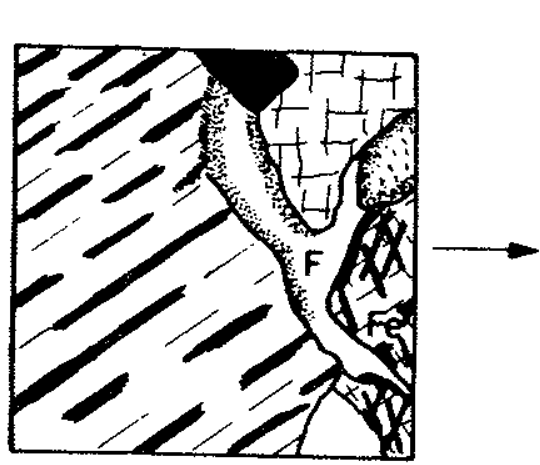

P - Plogioclósio

$N$ - Nefelino

E- Esfeno

H- Hornblendo
MICROSSISTEMA PLÁSMICO
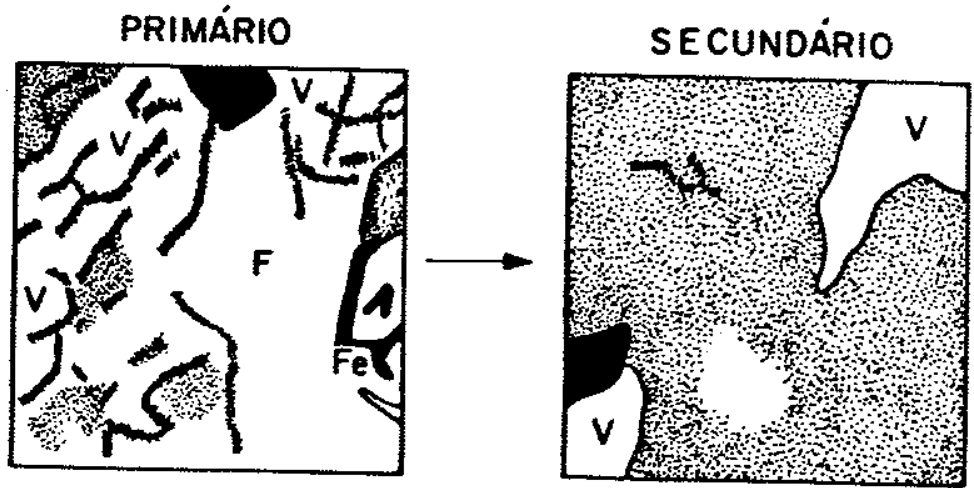
M- Mognetito
F - Fissuro
V- Vazio
PI - Plosmo

Fig. I5-EVOLUÇÃO dOS MICROSSISTEMAS DE ALTERAÇĀo NAS ROCHAS ALCALINAS 
A titanita parece o mineral mais resistente nesta rocha. Neste fācies, encontra-se ainda alguns fragmentos sãos. Sua alteração se dā atravēs da formação de uma fase amorfa ou criptocristalina de leucoxênio, que pode depois evoluir para gib bsita, ou sofrer lixiviação.

Nesta etapa observa-se, localmente, indīcios de intensa remobilização do ferro, possibilitada pela atuação do sistema fissural. Há preenchimento dos poros dos esqueletos de antigos minerais primārios, formando ferranes, ou ainda colorindo o plasma gibbsitico. Nota-se uma predomināncia da hematita so bre a goethita, tanto para o ferro remobilizado como para o ferro dos esqueletos.

Subsistem ainda boa parte dos minerais opacos.

As Figuras 14 e 15 sintetizam a alteração das rochas alcalinas aqui estudadas.

\subsection{Discussão}

A evolução mineralōgica e micromorfolōgica dos materiais foi estudada principalmente atravēs da microscopia ōptica, que permitiu confirmar aqui o carāter pontual da alteração, onde os microssistemas desempenham papel fundamental na evolução dos fenômenos de dissolução e recristalização dos minerais primärios e secundārios, conforme as idēias defendidas por vārios autores como Proust (1976), Meunier (1977) e outros citados na parte I.3.

0s fācies de alteração identificados nos mate riais bauxitizados a partir dos diferentes tipos litolögicos estudados, se caracterizam por propriedades morfolōgicas distintas, em termos de compactação, cor, estrutura, textura etc., propriedades estas que refletem em grande parte o estado de organização e a fase de evolução dos minerais constituintes. Estes fācies não estão distribuĩdos regularmente na vertical, num perfil simples, mas num perfil complexo, com intercalações e superposições 
daquelas propriedades, no caso dos perfis sobre rochas de composição granittica. Jä para as sequencias de alteração de rochas bäsicas e alcalinas, os fäcies sucedem-se normalmente.

A progressão da alteração que se instala na rocha sã, se dä a partir dos microssistemas de contato (Proust, 1976; Meunier, 1977), que podem se comportar diferentemente, segundo a natureza dos minerais em contato e o tipo de reação nele processada. Assim, nos materiais provenientes de rochas de composição granitica temos contatos neutros e contatos de desestabilização simultânea. Os primeiros, que ocorrem somente no material acima citado, permanecem quimicamente inertes: são os contatos quartzo-quartzo. No segundo tipo, alteram-se concomitan temente os minerais justapostos, ou os fragmentos de um mesmo mineral, situados de ambos os lados das superfïcies de desconti nuidades, como clivagens, geminações, fissuras e outras, 0correm em todas as litologias, envolvendo os diversos minerais primärios, excessão feita ao quartzo.

Qualquer que seja o tipo de contato, $\vec{e}$ frequente a impregnação por oxidos e hidrōxidos de ferro, provenientes da desestabilização da biotita.

No diabäsio, observam-se contatos reacionais, que atuaram apenas em profundidade, originando bordos de reação piro xénicos ao redor dos cristais de olivina, em contato com piroxe- nios ou plagiocläsios.

No material estudado estão caracterizados os microssistemas de alteração, definidos no capĩtulo introdutōrio.

0 microssistema de contato, caracteristico do in icio da alteração, tem um bom exemplo no caso da alteração dos nefelina-sienitos. Cristais de hornblenda apresentaram um caso típico da fase bissialitica que pode ocorrer no inicio da altera ção laterïtica, com vermiculitização nos microssistemas de conta to, que mais tarde evolui para microssistema fissural, quando então a vermiculita sé desestabiliza, resultando em ōxidos de ferro, com ou sem gibbsita. 
A porosidade de uma maneira geral, representa 0 sistema fissural e pode ou não apresentar deposição de material secundärio em suas paredes, formando cutanes gibbsiticos, ferru ginosos ou argilosos.

o material secundärio, que constitui o plasma neo formado a partir dos minerais primärios, quando "in situ", representa o plasma primārio, ou sistema plásmico primārio, que guarda ainda as feições estruturais, do material que o originou. Neste sistema, podem ocorrer modificações, como dissolução e reprecipitação, ou simples recristalização. 0 material resultante destes processos constitui o plasma secundārio, onde jä não se notam indicios quaisquer do material original.

A sequência de alteração verificada para os minerais primārios, apenas confirma as observações constantes na literatura.

No material bauxitizado sobre as rochas de composição granitica, o primeiro mineral a se alterar $\bar{e}$ o feldspato, sofrendo perda dos álcalis e da sîlica, restando a gibbsita como resĩduo de alteração. Nas amostras disponĩveis, não foi possivel distinguir a ordem de estabilidade entre as variedades de feldspato.

Entre os minerais micäceos presentes, a biotita se altera mais rapidamente, sendo frequentemente destruida por completo, antes que a muscovita e a sericita iniciem uma alteração significativa. o resultado da alteração da biotita pode ser um material caolinitico ou ferruginoso, sendo possivel tamberm sua total lixiviação, com excessão do ferro segregado do reticulo cristalino.

A muscovita e a sericita têm um comportamento semelhante, sendo muito estāveis; comumente encontram-se cristais inalterados, associados a horizontes completamente alterados e remobilizados. Quando alteradas, as sericitas resultam em caolinita, pseudomörfica. O mesmo è vālido para grande parte das muscovitas que, por outro lado, podem apresentar uma gibbsitização indireta, atravēs da dessilicificação da caolinita, ou mesmo 
direta, porēm raramente.

o quartzo pode sofrer alguma dissolução ou corro são, pela intensa atuação dos agentes de intemperismo. Nos hor zontes superficiais, nota-se o aumento do nümero de grãos trinca dos e corroídos.

No perfil sobre diabäsio, verifica-se que os pla giocläsios e ferromagnesianos tēm uma alteração aparentemente rāa pida, pois a transição rocha sã/cörtex totalmente alterado $\bar{e}$ brusca. Os primeiros sofrem uma gibbsitização direta, enquanto que a alteração dos ferromagnesianos tem como resĩduo apenas öxi dos e hidröxidos de ferro. A evolução dos anfibōlios e piroxênios parece ser semelhante com o correr da alteração, não sendo possivel distinguir a ordem de estabilidade entre eles, pelas amostras estudadas.

A olivina $\vec{e}$ tambëm rapidamente alterada, e seu resĩduo ferruginoso, goethitico, muito bem cristalizado, pode permanecer atē os ültimos estädios de alteração. A magnetita das fissuras dessas relĩquias ē resultado de uma alteração em profun didade, quando parte do ferro foi segregado do retīculo para as fissuras, na forma de magnetita.

Os minerais opacos, essencialmente magnetita, resistem bem ate o fäcies de rocha totalmente alterada, com estrutura preservada e aporte de material, onde apresentam-se quase completamente destruídos.

A presença de vermiculita não $\vec{e}$ significativa em termos quantitativos, mas confirma a fase bissialitica transitöria da Taterização, que desaparece ainda no inîcio da alteração, no fäcies de rocha totalmente alterada, com estrutura conservada.

Entre os feldspatöides e plagiocläsios das rochas alcalinas, as observações mostram uma leve diferença em termos de resistēncia; no cörtex da rocha, existem ainda fragmen tos sãos de plagiocläsios, enquanto todos os feldspatōides jä foram gibbsitizados, seja diretamente ou atravēs de uma fase a- 
morfa sîlico-aluminosa.

A hoirnblenda, cujo resīduo de alteração è essencialmente ferruginoso,via de regra hematītico, sofre uma fase bissialïtica no início de sua meteorização, de vermiculita, posteriormente destruida.

A titanita $\overline{\mathrm{e}}$ o mineral mais resistente, com excessão dos opacos,ilmenita e magnetita. Sua alteração ocorre por intermëdio de uma fase amorfa ou criptocristalina de leucoxēnio que, com o correr da alteração, evolui para gibbsita ou $\bar{e}$ totalmente lixiviado.

A figura 16 mostra esquematicamente a resistência dos minerais primärios com o correr da alteração, assim como o aparecimento dos minerais secundärios mais importantes.

A gibbsitização dos minerais primärios constituintes das rochas estudadas se dä direta ou indiretamente. No caso dos feldspatos, ela e sempre direta, em qualquer das Titologias. os feldspatōides podem apresentar uma fase intermediäria na sua gibbsitização, de material amorfo sîlicomaluminoso. outra fase intermediāria possīvel $\bar{e}$ a caolinita, praticamente obrigatōria na evolução das muscovitas. Jä a biotita, dificilmente alcança o estädio gibbsitico mas, quando o faz, $\vec{e}$ sempre atravēs da caolini zação prēvia.

A composição mineralögica dos nefelina-sienitos e, diabāsio permite uma bauxitização räpida e direta atravēs da alte ração ferralitica, pois os seus minerais primärios, feldspatōides e plagiocläsios principalmente, evoluem diretamente em gibbsita, atravēs da dessilicificação, com acumulação relativa em alumĩnio. Alëm disso, ocorre tambēm a acumulação absoluta, pela deposição do aluminio que sofre migração, em solução ou suspensão. 0 Al $\vec{e}$ um elemento considerado, a priori, imōvel no meio superficial, considerando-se que as āguas naturais tēm um pH entre 4 e 9 , in tervalo de imobilidade para o aluminio, conforme mostra a Figura 17. Contudo, a migração da alumina em solução ocorre e podemos ob servar seus efeitos. Este fato serā facilmente explicado se cons derarmos os microssistemas quimicos existentes nos contatos e des 
continuidades dos minerais, onde seja possivel a percolação das soluções, e onde reinam condiçōes prōprias, variäveis de ponto para ponto, segundo a velocidade de percolação, a natureza das soluções em termos de concentração, temperatura, e a mineralogia, cuja influência reside no conceito de $\mathrm{pH}$ de abrasão, que $\bar{e} o \mathrm{pH}$ apresentado pela solução em contato com cada tipo mineralōgico. Es te $\mathrm{pH} \overrightarrow{\mathrm{e}}$ sempre alcalino no caso dos silicatos, que podem ser enca rados como sais de äcido fraco (äcido silicicico) e bases fortes.Na sërie dos feldspatos, por exemplo, a albita tem um pH de abrasão entre 9 e 10, enquanto que a anortita e o feldspato potäsico apresentam um valor de 8 . Os piroxēnios e olivinas, assim como os anfibölios, apresentam valores mais elevados (10 e 11). 0s öxidos primärios e secundärios e os silicatos secundārios apresentam vam lores de $\mathrm{pH}$ de abrasão muito menos elevados, e dentro do interva1o normal ( 5 a 7 ).

Desta forma, nos micromeios são comumente atingidos altos valores de pH, maiores que 9,5 e que permitem a mobilização do alumīnio, que serā precipitado apös um certo transporte, ao encontrar condições favoräveis.

Embora os feldspatos das rochas de composição granîtica sofram igualmente uma pronta gibbsitização, a bauxitizaça neste caso não $\overrightarrow{\mathrm{e}}$ um processo simples como ocorre para as rochas alcalinas. A presença, em grandes quantidades de muscovita, que se transforma por degradação, favorecendo a formação de argilo mi nerais (caolinita, neste caso), muito estāveis nas condições superficiais, dificulta a bauxitização do material, pois exige uma evolução longa em condições excepcionais de drenagem para uma dessilicificação (Lelong et al, 1976). Por outro lado, mesmo sabendo-se muito intensas as condições de lixiviação na ārea, não se pode desprezar a influência do quartzo no fornecimento de sĩ $\underline{i}$ ca ao meio que se em nosso caso não chegou a impedir, deve ter, ao menos, retardado a gibbsitização.

A ausēncia de quartzo na rocha matriz da bauxita e geralmente considerada fundamental (Gardner, 1970). Segundo Kit trick (1969), a atividade em $\mathrm{H}_{4} \mathrm{SiO}_{4}$ determina o mineral a ser pre cipitado nas neoformações (sîlica amorfa, montmorilonita, caolini ta ou gibbsita, conforme a Figura 18), e o argumento usado $\overline{\mathrm{e}}$ que 


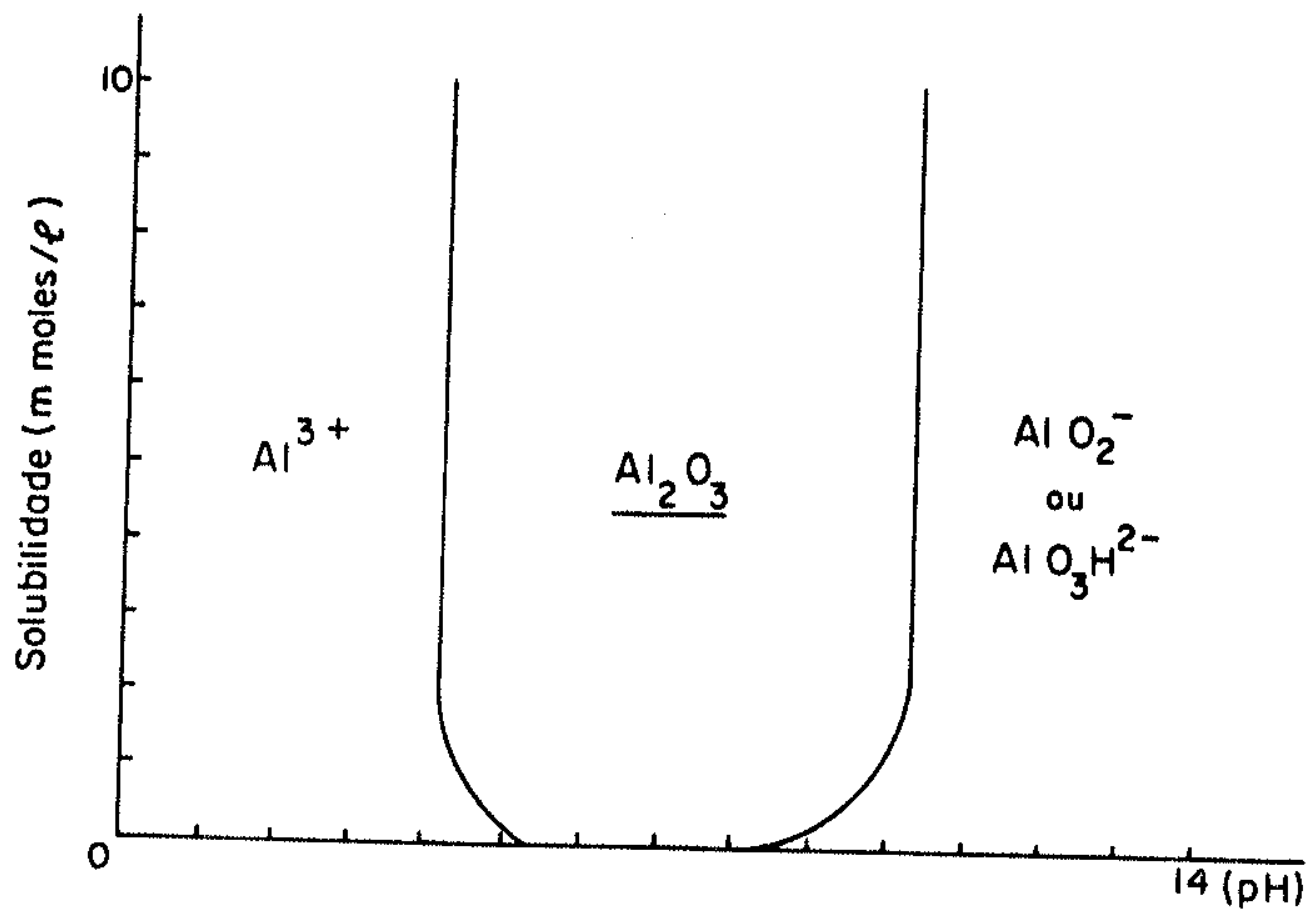

Fig.17-SOLUBILIDADE DO ALUMINIO EM FUNÇȦO DO pH. Fonte: F.C. Loughnon, 1969.

$$
\mathrm{pH}-\frac{1}{3} \mathrm{pAi^{3+ }}
$$

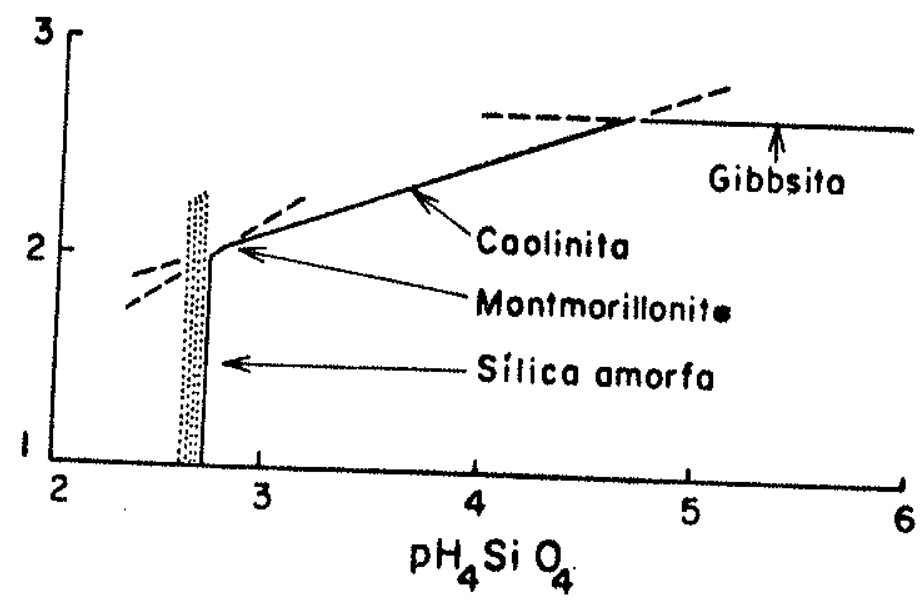

Fig. 18-DIAGRAMA DE ESTABILIDADE PARA ALGUNS MINERAIS NO SISTEMA $\mathrm{Al}_{2} \mathrm{O}_{3}, \mathrm{SiO}_{2}, \mathrm{H}_{2} \mathrm{O}$, A $25^{\circ} \mathrm{C}$ E 1 ATM. A LINHA DE ESTABILIDADE PARA CADA MINERAL É CONTINUUA, QUANDO ELE É O MINERAL MAIS ESTÁVEL DO GRUPO.

(Fonte J.A. Kiftrick, 1969.) 
havendo quartzo no meio de alteração, o nĩvel em sîlica dissolvi da nunca serā baixa o suficiente para permitir a dessilicifica ção dos minerais proto-gibbsïticos. No caso da gibbsitização a partir da dissolução incongruente da caolinita, a ausēncia de quartzo tambēm è uma clāssica premissa, segundo dados de Garrels e Christ (1967) e Millot e Fauck (1971)(apud Bocquier, 1976).A1ēm disso, acredita-se que pode haver em certas situações, atē mesmo, uma ressilicificação da gibbsita, pela sîlica proveniente da dissolução do quartzo.

Sabe-se hoje, contudo, atravēs da aplicação da cinētica, que em perfis quartzosos, com excepcional drenagem, $\bar{e}$ possîvel que a concentração em sîlica dissolvida nas soluções percolantes nunca atinja um nỉvel que dificulte a precipitação de hidróxidos de alumīnio. Alēm disso, existe a possibilidade da existência de "filmes" ferruginosos envolvendo os grãos de quart zo, dificultando sua dissolução e assim, diminuindo a influência do quartzo (Loughnan e Bayliss, 1961).

As caracterīsticas morfolōgicas da bauxita de Mo gi das cruzes, sem uma uniformidade na sequência dos fācies de alteração, com intercalações e inversões, e indicando retrabalha mento, dificultam a compreensão de sua evolução, sobre a qual algumas considerações são feitas no capītulo final. Ao contrārio, a bauxitização do diabāsio e dos nefelina-sienitos se deu "in situ", sem fases intermediārias, num processo simples, direto e rápido, em que todos os fatores envolvidos favoreceram a acumula ção do alumînio.

2. Evolução Quĩmica dos Materiais

\subsection{Resultados}

Os dados relativos às anāilises quỉmicas, no caso das amostras de diabāsio, de nefelina-sienitos e seus produtos de alteração, referem-se a sequencias normais de alteração, enquanto que no caso dos materiais intemperizados a partir de rochas de composição granītica, as anāitises referem-se aos hor 
zontes remobilizados, classificados como caolim, argila aluminosa ou bauxītica, e bauxita (V. ỉtem II - 1 Materiais). 0s dados quỉmicos destes ültimos materiais, foram fornecidos pela Empresa' de Mineração B.F.Lopes, de Mogi das Cruzes; as rochas alca linas e bäsicas e seus fācies intemperizados foram analisados no Instituto de Geociências da USP, Laboratório de Geoquīmica, pela prōpria autora.

As tabelas 1, 2 e 3 mostram a composição quỉmica, expressa em porcentagem em peso ou em ppm, de todos os materiais estudados.

Quando, durante a alteração, hā conservação das estruturas originais, è possīvel calcular a quanticiade, em peso, de cada öxido por unidade de volume, nos fácies alterados, e comparā-la com a quantidade no mesmo volume de rocha fresca, ava liando-se assim, as perdas e ganhos reais nos diversos fäcies de um perfil, em relação à rocha sã em sua base. Tem-se então,o balanço geoquỉmico da alteração, atravēs do chamado cālculo isovoTume (Bonifas e Millot, 1955).

Estes cálculos puderam ser feitos para as rochas alcalinas e bāsicas, a partir dos dados quỉmicos expressos em porcentagens volumētricas, obtidos da seguinte forma:\% volumētri ca $(g / 100 \mathrm{cc})=\%$ em peso $(\mathrm{g} / 100 \mathrm{~g}) \times \mathrm{D} . \mathrm{A} .(\mathrm{g} / \mathrm{cc})$.

o balanço geoquỉmico, ou o cälculo das perdas e ganhos reais de uma amostra alterada $\left(A_{2}\right)$ em relação à amostra sã $\left(A_{1}\right)$ correspondente, ē dado pela equação: $\Delta=\left(D_{.} A_{0}\right)_{2} x_{2}-\left(D_{0} A_{0}\right)_{1} x_{1}$, onde $x \bar{e}$ a porcentagem em peso de cada ōxido. Para um resultado positivo, tem-se caracterizado um ganho daquele ōxido durante a alteração, e para um resultado negativo, uma perda.

A composição quỉmica expressa em porcentagem volumētrica estā na tabela 4. A tabela 5 mostra o balanço geoquỉmi co, feito para as sequências de alteração das rochas alcalinas e bāsicas. As perdas e ganhos reais dos diversos ōxidos são indica das neste balanço geoquĩmico, como tambëm na tabela 6 , onde cons ta o cālculo da porcentagem de variação do teor absoluto de cada öxido em cada fācies, com relação à rocha sã. 


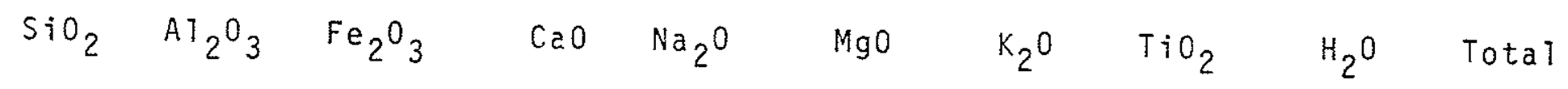

\begin{tabular}{|c|c|c|c|c|c|c|c|c|c|c|c|}
\hline $\mathrm{SCl}$ & & 50,94 & 11,90 & 9,81 & 12,96 & 1,65 & 9,62 & 0,15 & 1,0 & 1,04 & 99,07 \\
\hline $\mathrm{SC} 2$ & & 15,86 & 27,97 & 23,11 & 0,11 & 0,08 & 0,30 & 0 & 2,25 & 29,46 & 99,14 \\
\hline $\mathrm{SC} 3$ & & 12,84 & 31,90 & 22,25 & 0,23 & 0,03 & 0,74 & 0,01 & 1,64 & 29,81 & 98,85 \\
\hline $\mathrm{SC} 4$ & & 1,94 & 41,98 & 19,82 & 0,23 & 0,01 & 0,02 & 0 & 1,82 & 33,74 & 97,62 \\
\hline SFI & & 55,88 & 18,84 & 1,83 & 1,13 & 13,42 & 0,13 & 6,70 & 0,20 & 1,0 & 99,13 \\
\hline SF2 & & 20,20 & 35,44 & 6,94 & 0,34 & 1,87 & 0,02 & 4,52 & 0,63 & 27,9 & 97,86 \\
\hline SF 3 & & 10,46 & 43,84 & 7,88 & 0,01 & 1,08 & 0,04 & $.3,47$ & 1,19 & 31,20 & 99,17 \\
\hline SGI & & 55,86 & 19,99 & 1,89 & 1,01 & 13,88 & 0,13 & 6,56 & 0,70 & 2,50 & 102,52 \\
\hline SG2 & & 12,22 & 39,78 & 6,76 & 0,23 & 1,79 & 0,14 & 3,66 & 0,84 & $31,9.0$ & 97,32 \\
\hline SG3 & & 7,92 & 45,10 & 7,54 & 0,11 & 1,29 & 0,10 & 2,05 & 1,03 & 32,10 & 97,24 \\
\hline S1 & & 55,87 & 19,42 & 1,86 & 1,07 & 13,65 & 0,13 & 6,63 & 0,45 & 1,75 & 101,33 \\
\hline$\$ 2$ & & 16,21 & 37,61 & 6,85 & 0,29 & 1,83 & 0,08 & 4,09 & 0,74 & 29,55 & 97,25 \\
\hline \$3 & & 9,19 & 44,47 & 7,71 & 0,06 & 1,19 & 0,07 & 2,76 & $i, 11$ & 31,65 & 98,21 \\
\hline SC & 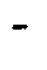 & Diabäs & & & & & & & & & \\
\hline SF & - & Nefeli & na-sien & o (Tex & (ina) & & & & & & \\
\hline$S G$ & - & Nefeli & na-Sie & 0 (Tex & arosse & & & & & & \\
\hline S & - & Nefeli & na-sien & 0 (Mēd & & & & & & & \\
\hline
\end{tabular}

TABELA 1 - COMPOSIÇAOO QUTMICA, EM \% PESO, DO DIABASIO, NEFELINA-SIENITOS E SEUS 
$\mathrm{Mn} \quad \mathrm{Ni} \quad \mathrm{Cu} \quad \mathrm{Co} \quad \mathrm{Ga}$

$\begin{array}{lccccl}\text { SC1 } & 2,740 & 0,485 & 0,118 & 0,177 & \operatorname{tr} \\ \text { SC2 } & 0,360 & 0,145 & 0,176 & 0,091 & 2 \\ \text { SC3 } & 0,270 & 0,185 & 0,196 & 0,059 & 3 \\ \text { SC4 } & 0,160 & 0,125 & 0,153 & 0,087 & \operatorname{tr} \\ \text { SF1 } & 4,050 & \operatorname{tr} & 1,370 & 0,087 & \operatorname{tr} \\ \text { SF2 } & 2,250 & 0,085 & 0,007 & 0,079 & 1 \\ \text { SF3 } & 3,450 & 0,085 & 0,018 & 0,063 & 1 \\ \text { SG1 } & 2,000 & 0,075 & 0,001 & 0,087 & 1 \\ \text { SG2 } & 5,800 & 0,085 & 0,015 & 0,087 & 1 \\ \text { SG3 } & 1,710 & 0,085 & 0,007 & 0,087 & 2\end{array}$

TABELA 2 - TEORES DE ELEMENTOS MENORES E TRAÇOS NOS MATERIAIS ESTUDADOS, EM PPM. 


$\begin{array}{lrccccccccc} & \mathrm{SiO}_{2} & \mathrm{Al}_{2} \mathrm{O}_{3} & \mathrm{Fe}_{2} \mathrm{O}_{3} & \mathrm{CaO} & \mathrm{Na}_{2} \mathrm{O} & \mathrm{MgO} & \mathrm{K}_{2} \mathrm{O}^{2} & \mathrm{TiO}_{2} & \mathrm{H}_{2} \mathrm{O} & \text { Total } \\ M C-4 & 60,9 & 26,6 & 1,25 & \operatorname{tr} & 0,03 & 0,20 & 0,43 & 1,05 & 9,53 & 99,99 \\ M C-4 & 66,0 & 21,9 & 2,60 & \operatorname{tr} & 0,07 & 0,30 & 1,48 & 0,21 & 7,46 & 100,02 \\ M C-5 & 52,1 & 31,4 & 2,37 & \operatorname{tr} & 0,03 & 0,31 & 0,43 & 1,82 & 11,50 & 99,96 \\ M C-6 & 18,1 & 54,7 & 1,14 & - & - & - & - & 0,09 & - & - \\ M C-6 & 8,0 & 60,7 & 0,79 & - & - & - & - & 0,09 & - & - \\ M C-6 & 14,9 & 53,9 & 3,37 & - & - & - & - & 0,40 & - & - \\ M C-6 & 29,7 & 47,0 & 1,53 & - & - & - & - & 0,19 & - & - \\ M C-6 & 25,1 & 44,0 & 8,21 & - & - & - & - & 2,26 & - & -\end{array}$

TABELA 3 - COMPOSIÇAO QUIMICA DOS HORIZONTES REMOBILIZADOS, PROVENIENTES DA ALTERAÇAO DE ROCHAS GRANITICAS, EM \% EM PESO

MC-4: caolim; MC-5: argilas bauxiticas; MC-6: bauxita. 


$\begin{array}{lrrrrrrrrr} & \mathrm{SiO}_{2} & \mathrm{Al}_{2}{ }^{\mathrm{O}} 3 & \mathrm{Fe}_{2}{ }{ }_{3} & \mathrm{CaO} & \mathrm{Na}_{2}{ }^{\mathrm{O}} & \mathrm{MgO} & \mathrm{K}_{2} \mathrm{O} & \mathrm{TiO}_{2} & \mathrm{H}_{2} \mathrm{O} \\ & & & & & & & & & \\ \text { SC1 } & 156,40 & 36,50 & 30,10 & 39,79 & 5,10 & 29,50 & 0,50 & 3,10 & 3,20 \\ \text { SC2 } & 21,10 & 37,20 & 30,70 & 0,15 & 0,10 & 0,40 & 0 & 3,00 & 39,20 \\ \text { SC3 } & 15,00 & 37,30 & 26,00 & 0,27 & 0,04 & 0,20 & 0,01 & 1,90 & 34,90 \\ \text { SF1 } & 140,30 & 47,30 & 4,60 & 2,84 & 33,70 & 0,30 & 16,80 & 0,50 & 2,51 \\ \text { SF2 } & 29,50 & 51,70 & 10,10 & 0,50 & 2,70 & 0,03 & 6,60 & 0,90 & 40,70 \\ \text { SF3 } & 11,00 & 52,20 & 8,30 & 0,01 & 1,10 & 0,04 & 3,60 & 1,20 & 32,80 \\ \text { SG1 } & 145,20 & 54,60 & 4,90 & 2,63 & 36,10 & 0,30 & 17,10 & 1,80 & 6,50 \\ \text { SG2 } & 13,20 & 63,60 & 10,80 & 0,37 & 2,90 & 0,20 & 3,50 & 1,30 & 50,00 \\ \text { SG3 } & 9,40 & 53,70 & 9,00 & 0,13 & 1,50 & 0,10 & 2,40 & 1,20 & 38,20 \\ \text { S1 } & 142,80 & 51,00 & 4,80 & 2,74 & 34,90 & 0,30 & 17,00 & 1,20 & 4,50 \\ \text { S2 } & 21,40 & 57,70 & 10,50 & 0,44 & 2,80 & 0,10 & 5,10 & 1,10 & 45,40 \\ \text { S3 } & 10,20 & 53,00 & 8,70 & 0,07 & 1,30 & 0,10 & 3,00 & 1,20 & 35,50\end{array}$

TABELA 4 - COMPOSIÇÃO QUIMICA, EXPRESSA EM PORCENTAGENS VOLUMETRICAS $(\mathrm{g} / 100 \mathrm{cc})$, DO DIABASIO, NEFELINA-SIENITOS E SEUS PRODUTOS DE ALTERAÇO 


$\begin{array}{lccccccccc} & \mathrm{SiO}_{2} & \mathrm{Al}_{2} \mathrm{O}_{3} & \mathrm{Fe}_{2} \mathrm{O}_{3} & \mathrm{CaO} & \mathrm{Na}_{2} \mathrm{O} & \mathrm{MgO} & \mathrm{K}_{2} \mathrm{O} & \mathrm{TiO}_{2} & \mathrm{H}_{2} \mathrm{O} \\ & & & & & & & & & \\ \mathrm{SC}-2 & -135,30 & +0,70 & +0,60 & -39,64 & -5,00 & -29,10 & -0,50 & -0,10 & +36,00 \\ \mathrm{SC}-3 & -141,40 & +0,80 & -4,10 & -39,52 & -5,10 & -29,30 & -0,49 & -1,20 & +31,70 \\ \mathrm{~S}-2 & -121,40 & +6,70 & +5,70 & -2,30 & -32,10 & -0,20 & -11,90 & -0,10 & +40,90 \\ \mathrm{~S}-3 & -132,80 & +2,00 & +3,90 & -2,70 & -33,60 & -0,20 & -14,00 & 0 & +31,00\end{array}$

TABELA 5 - BALANÇO GEOQUimico PARA A ALTERAÇAO do DIABASIO E DOS NEFELINA - SIENITOS (MEDIA)

$\begin{array}{lccccccccc} & \mathrm{SiO}_{2} & \mathrm{AT}_{2} \mathrm{O}_{3} & \mathrm{Fe}_{2} \mathrm{O}_{3} & \mathrm{CaO} & \mathrm{Na}_{2} \mathrm{O} & \mathrm{MgO} & \mathrm{K}_{2} \mathrm{O} & \mathrm{TiO}_{2} & \mathrm{H}_{2} \mathrm{O} \\ \mathrm{SC}-2 & -86,50 \% & +7,90 \% & -2,00 \% & -99,60 \% & -98,00 \% & -98,60 \% & -100,00 \% & -3,20 \% & -990,60 \% \\ \mathrm{SC}-3 & -90,40 \% & +2,20 \% & +13,60 \% & -99,30 \% & -99,20 \% & -99,20 \% & -100,00 \% & -38,70 \% & +990,00 \% \\ \mathrm{~S}-2 & -85,00 \% & +0,10 \% & +11,88 \% & -83,90 \% & -92,00 \% & -66,70 \% & -70,00 \% & -20,00 \% & +908,90 \% \\ \mathrm{~S}-3 & -93,00 \% & +0,04 \% & +81,30 \% & -97,40 \% & -96,30 \% & -65,70 \% & -82,40 \% & 0 & +688,90 \%\end{array}$

TABELA 6 - PERdAs $(-)$ OU GANHOS $(+)$, EM PORCENTAGEM, APRESENTAdOS PELAS AMOSTRAS EM RELAÇAO $\bar{A}$ ROCHA SA 
Nas Figuras 19 e 20 , o mesmo balanço geoquímico $\bar{e}$ representado graficamente, relacionando a variação dos teores absolutos (porcentagens volumëtricas) dos diversos öxidos, em função da densidade aparente, que pode ser tomada como um indice de alteração nos processos isovolume. Desta forma, temos caracterizado o comportamento dināmico dos diversos ōxidos durante a al teração.

\subsection{Discussão}

A partir dos balanços geoquỉmicos e gräficos de variação dos teores absolutos dos diversos óxidos analisados, pode-se tentar a interpretação do processo de alteração das rochas alcalinas e bäsicas, do ponto de vista quínico.

A hidrōlise dos silicatos e evidenciada pela eliminação da maioria dos elementos, principalmente os alcalinos e alcalino-terrosos, juntamente com a sîlica.

0 aluminio sofre nas duas litologias estudadas, um aumento por unidade de volume, embora pouco significativo, o que nos obriga a admitir que, embora não haja perturbação das estrutu ras originais, houve uma acumulação absoluta, paralelamente à acú mulação relativa, atravēs de transporte de cima para baixo, vertí cal ou lateral, a partir das camadas de bauxita mais evoluidas, que podem sofrer uma certa lixiviação. Não é possivel, entretanto, estimar quanto do aluminio permaneceu "in situ", e quanto foi importado. A diferença entre o teor em Al da rocha sã, e o teor do produto alterado, não representa necessariamente todo o alum nio importado, pois uma parte deste aluminio da rocha sã pode ter sido eliminada durante a hidrölise, aumentando assim a parce1 a de contribuição alōctone do total presente na rocha alterada.

0 ferro sofre um grande aumento na alteração do nefelina sienito, embora o produto final seja relativamente pouco ferruginoso, o que é explicado pelo seu baixo teor inicial. No caso do diabäsio, este elemento sofre um aumento pouco significa tivo na primeira fase de alteração, e uma perda tambēm pequena 

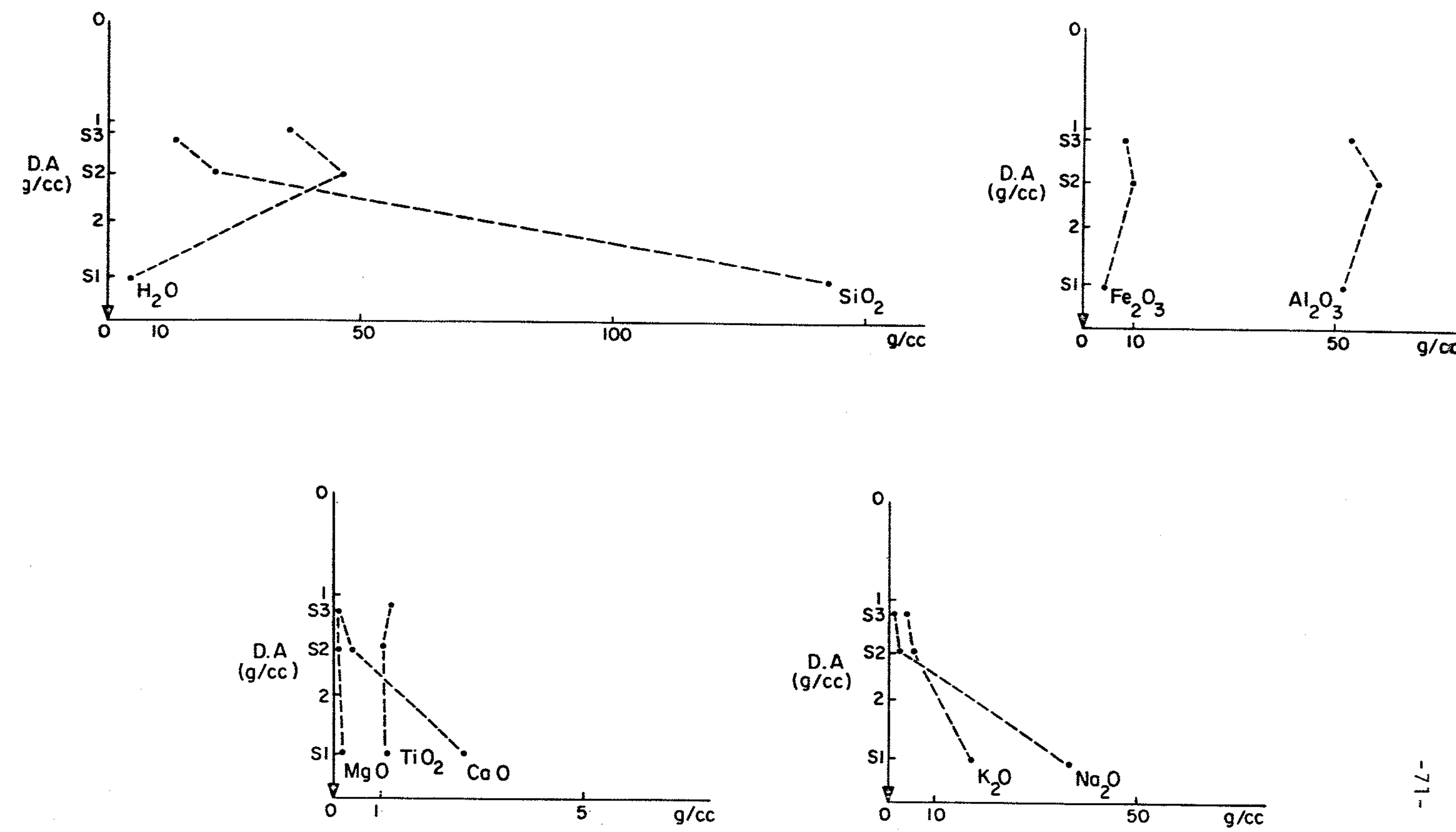

Fig. 19 - VARIAÇĀO DOS TEORES ABSOLUTOS DOS DIVERSOS ÓXIDOS $(g / 100 \mathrm{cc})$, EM FUNÇĀO DA DENSIDADE APARENTE $(g / c c)$, PARA NEFELINA-SIENITO E SEUS PRODUTOS DE ALTERAÇĀO. 
na segunda; o caräter ferruginoso da bauxita resultante $\bar{e}$ tambēm justificado pelo teor inicial, bastante alto.

Quanto ao ganho de ferro por adição externa, $\bar{e}$ vă lido o mesmo raciocinio utilizado para o aluminio.

Desta forma, temos, nas sequéncias estudadas, que as estruturas originais das rochas sãs deixadas pela maioria dos elementos durante a hidrölise, passam a ter como suporte quase que exclusivamente os öxidos hidratados de Fe e de Al. Sem dü vida, uma parte destes elementos è autöctone, resíduo da alteração ferralïtica, mas outra parte provëm de processos iluviais.

0 comportamento do titānio ē diferente para cada um dos casos estudados. Na alteração do diabäsio, este elemento $\vec{e}$ eliminado continuamente, mas apenas em parte, ao passo que na alteração do nefelina-sienito, mantēm-se constante no final, embora passe por uma ligeira perda intermediäria. Este fato esta relacionado com a permanēncia da titanita durante a alteração.

Alguns elementos traços foram dosados, como $\mathrm{Mn}$, $\mathrm{Ni}, \mathrm{Cu}$, Co e Ga. Verificou-se um comportamento irregular, provavelmente pelo pequeno nümero de anälises.

A alteração se desenvolve com uma razoāvel adição de ägua aos horizontes alterados (balanço positivo), representando o ünico ganho real nos fäcies onde a alteração não destrōi as estruturas, exceção feita ao ferro na primeira etapa da alteração dos nefelina-sienitos, conforme evidenciado pelo balan ço geoquĩmico.

0 s resultados das anälises do material sobre rochos de composição granitica atestam a heterogeneidade de composição dos horizontes retrabalhados. O material argiloso (caolini ta), e rico em alumina, e a bauxita è rica em silica e ferro,mas com teores muito variāveis. 
IV. CONSIDERAÇOES FINAIS

Durante o desenvolvimento deste trabalho, alquns aspectos importantes foram evidenciados e serão discutidos nesta parte final, com relação aos fatores controladores da bauxitização, aos processos de bauxitização e sua caracterização geoquĩmi ca, bem como à cronologia da alteração que gerou as bauxitas estudadas.

1. Controles Atuantes na Bauxitização

A importāncia exercida pela concentração das solu ções, e sua velocidade de percolação foi evidenciada durante os estudos micromorfolōgicos. Essas caracterīsticas da percolação determinam o comportamento e estabilidade dos minerais primārios e secundārios. Podemos utilizar o exemplo da deposição de gibbsi ta nas fissuras e contornos de grãos de quartzo em dissolução, que representa a co-existência de fenômenos aparentemente mutuamente exclusivos, e que somente se explica atravēs de uma räpida circulação das āguas com teor em sỉlica dissolvida nunca suficiente para impedir a neoformação da gibbsita. Esta ē uma situação tïpica do sistema fissural, definido por Proust (1976) e Meunier (1977).

Em Curucutu e em Lavrinhas, a alta porcentagem de gibbsita jā no cōrtex de alteração da rocha, evidencia a ação de processos de lixiviação intensa em tempo relativamente curto. Verifica-se, portanto, a grande importância da alta pluviosidade registrada nas āreas, ou do clima como um todo, bastante agressi vo. Da mesma forma, verifica-se o papel da posição topogrāfica dos depósitos e da estrutura e textura da rocha, que condiciona a dinâmica da āgua, favorāvel ao rāpido escoamento das āguas de drenagem em todos os casos estudados.

Contudo, mesmo num meio global agressivo, a ocorrência de vermiculita em pequena escala na alteração do diabāsio, representando a fase bissialïtica transitōria da laterização (Maignien,1961, Chatelin, 1974), atesta a importāncia dos micros- 
sistemas, que podem apresentar condições muito particulares e di versas das condições mēdias globais do perfil ou do depōsito.

A ocorrência de material sỉlico-aluminoso de natureza amorfa na alteração das rochas alcalinas representa igual mente uma evidência de que ocorrem pontualmente condições menos agressivas, num meio globalmente agressivo.

Em Mogi das Cruzes, o fator 1 imitante da gibbsitização global è o fator litolōgico. Embora os controles climāti co e topogrāfico ofereçam condições favorāveis à alitização, o carāter quartzoso e micāceo da litologia inicial dificulta a rāpida dessilicificação do meio,determinando a formação de caolini ta em grande quantidade, proveniente das micas, mas existindo ainda a gibbsitização direta dos feldspatos.

Neste caso, a gibbsitização total do material re quer um tempo mais longo de evolução, onde atuem as mesmas condi ções ideais de clima e drenagem interna dos perfis, para a dess $\underline{i}$ licificação da caolinita formada.

Conclui-se que a ação do controle litológico não muda o rumo da alteração, sempre em direção à alitização, mas po de retardā-1o, como no caso de Mogi das Cruzes, ou influir na composição da bauxita final, ferruginosa, no caso de Curucutu,ou pura, no caso de Lavrinhas.

Nos solos sobre o tälus alcalino, em Lavrinhas, observa-se um fenōmeno não generalizado, que evidencia o papel da matēria orgānica existente em abundāncia no topo dos perfis, e que provoca a ocorrência de pHs baixos o suficiente para dissolver todo ou quase todo o alumīnio, que migra para baixo, depositando-se sob a forma de nōdulos ou concreções gibbsïticas ao encontrar nīveis menos àcidos, onde a influência da matēria orgāni ca é menor, resultando num aspecto de camada de seixos, na base do perfil do solo. 


\section{Os Processos de Bauxitização}

A bauxitização das ocorrēncias estudadas ocorreu atravēs de dois processos. 0 primeiro, que se instala logo no inĩcio da alteração, e o de acumulação relativa do aluminnio,pela perda de todos os outros elementos, sendo a bauxita, um residuo "in situ" da evolução superficial da rocha. Neste caso, o mecanismo envolvido é o de deśsilicificação, tanto dos silicatos pri mários constituintes da rocha, como da caolinita secundāria.

0 outro processo, de acumulação absoluta, atua nos niveis mais evoluĩdos. As remobilizações, em maior ou menor escala,são facilitadas pela alta porosidade, e ocorrem por migra ção da alumina em solução verdadeira, coloidal, ou em suspensão. Neste processo, o plasma primário é desestabilizado e recristali zado ou redepositado, formando o plasma secundārio, onde pode não haver mais nenhum sinal das estruturas originais. A iluviação è um fenômeno importante na bauxitização estudada, formando feições características, os "cutanes", de natureza argilosa (caolinitica), gibbsitica e/ou ferruginosa.

Em Curucutu e em Lavrinhas, observa-se com facilidade a evolução da bauxitização. Nos fācies iniciais, prōximos à rocha sã, o processo atuante è de acumulação relativa, atravēs de uma alteração do tipo isovolume, com conservação das estruturas, onde as bases e o silĩcio liberados na hidrōlise são exportados do perfil, e o ferro è acumulado juntamente com o aluminio.

Nos fācies maìs evoluĩdos, evidencia-se o papel das remobilizações, ocasionando desde pequenas perturbações atē destruição total das texturas e estruturas originais, e promoven do a acumulação absoluta do aluminio e do ferro, respectivamente aluminificação e ferrificação.

Em Mogi das Cruzes, trata-se de material secundā rio, jă retrabalhado, e não existe esta sucessão nitida da evolu ção dos processos num perfil vertical. Contudo, é possivel obser var regiões das amostras onde as estruturas originais estão ainda conservadas, atravês da acumulação relativa do aluminio pela 
partida dos outros elementos, assim como tambēm se observa regiões apresentando deposição de material remobilizado e acumulado de maneira absoluta, isto é, aluminificação e ferrificação.

A natureza complexa dos perfis nesta ärea, deixa dūvidas quanto à interpretação de sua evolução, sugerindo a poss bilidade de flutuações nas condições controladoras do processo in temperico, significando mudanças no rumo da alteração atravēs do tempo, que resultaram na irregularidade observada dos horizontes em termos de composição mineralögica, ocorrendo desde horizontes bauxiticos ate predominantemente caoliniticos, passando por horizontes de composição intermediāria.

3. A Caracterização Geoquỉmica dos Processos de Alteração

Nos materiais estudados, caracteriza-se a hidrōl se como mecanismo de alteração superficial, com suas trēs grandes tendências evolutivas, conforme definido por pedro (1964, 1966), tendo como critérios o comportamento dinämico da sīicica e do alu mĩnio.

A alitização è a tendēncia final em todos os casos. Sobre as rochas alcalinas e bäsicas, o produto final apresen ta um sensivel empobrecimento em sîlica, com a relação $\mathrm{K}_{i}$ (Si0, $_{2}$ $\mathrm{Al}_{2} \mathrm{O}_{3}$ ) igual a 0,2 para a bauxita sobre rochas alcalinas, e 0,1 para o produto de alteração do diabāsio.

0 comportamento do ferro é idêntico ao do alumi nio em todos os casos estudados, o que justifica a denominação de ferralitização para o processo atuante, significando a simultanei dade entre a ferruginização dos minerais ferromagnesianos e a alitização dos feldspatos e feldspatōides.

Considerando o teor inicial em ferro do diabäsio e dos nefelina-sienitos, compreende-se os produtos finais deles formados, altamente ferruginoso para o primeiro, e pobre em ferro para os segundos. 
Com relação às rochas de composição granittica de Mogi das Cruzes, ocorre um paralelismo entre os processos geoqui micos: as muscovitas sofrem uma monossialitização, as biotitas ferruginização e monossialitização concomitantes (fersialitização), enquanto que os feldspatos sofrem uma alitização.

A ocorrēncia da monossialitização reflete a dificuldade do meio na dessilicificação total de certos minerais, o que acabarā ocorrendo com o tempo, e reforça a idēia de que a ferralitização se desenvolve mais facilmente quanto mais pobre em sîlica for o material inicial.

A bissialitização estä presente na alteração de alguns cristais de hornblenda logo no inîcio da alteração tanto do diabäsio como do nefelina-sienito, na forma de vermiculita, cu ja relação $k i \bar{e}$ superior a 2. Este fenōmeno caracteriza a fase bissialïtica transitōria da ferralitização (Maignien, 1961; Chatelin, 1974), com uma expressão quantitativa e temporal muito pe quena.

Os cristais de titanita das rochas alcalinas, podem apresentar na sua alteração uma fase intermediāria de hemissialitização, pela formação de material amorfo sîlico-aluminoso, que $\bar{e}$ rapidamente gibbsitizado, não chegando a alcançar importân cia na evolução da rocha.

0 quadro da Figura 21 apresenta uma sintese da evolução das rochas estudadas.

4. Cronologia das Alterações

As observações efetuadas nas äreas de Mogi das Cruzes e Curucutu, aliadas às informações obtidas na bibliografia, levam a crer que ambas as āreas representariam resíduos da superfĩcie de erosão neogênica, de De Martonne (1943-44), de ida de plio-pleistocênica. Contudo, os depōsitos das duas äreas tēm caracteristicas diferentes, o que distanciaria as suas idades. 0 caräter autōctone da bauxita de Curucutu coloca a alteração como 


\begin{tabular}{|c|c|c|c|c|}
\hline ROCHA & $\begin{array}{l}\text { PRINCIPAIS } \\
\text { MINERAIS }\end{array}$ & $\begin{array}{c}\text { PROCESSO GEOQUIMICO } \\
\text { DOMINANTE }\end{array}$ & $\begin{array}{c}\text { MINERAL SECUNDARIO } \\
\text { RESULTANTE }\end{array}$ & PRODUTO FINAL \\
\hline Nefelina-Sient to & $\left.\begin{array}{l}\text { Feldspatos } \\
\text { Feldspatōides }\end{array}\right]$ & $\begin{array}{l}\text { - A titização- } \\
\text {-(Ferruginização) - }\end{array}$ & $\begin{array}{l}\text { Gibbsita } \\
(\bar{o} x . e \text { hidrōx.de Fe) }\end{array}$ & Bauxita \\
\hline Diabāsio & $\begin{array}{l}\text { Feldspatos } \\
\text { Anfibōlios } \\
\text { Piroxēnios }\end{array}$ & $\begin{array}{l}\text { - Alitização- } \\
\text { - Ferruginização - }\end{array}$ & $\begin{array}{l}\text { Gibbsita } \\
\text { (ōx.e hidrōx.de Fe) }\end{array}$ & $\begin{array}{l}\text { Bauxita } \\
\text { Ferruginosa }\end{array}$ \\
\hline $\begin{array}{l}\text { Rochas de Composição } \\
\text { granitica }\end{array}$ & $\begin{array}{l}\text { Feldspatos } \\
\text { Muscovita- } \\
\text { Biotita } \\
\text { Quartzo }\end{array}$ & \begin{tabular}{|} 
- Alitização \\
- Fersialitização- \\
Alitização- \\
-Dissolitização Parcial
\end{tabular} & $\begin{array}{l}\text { Gibbsita } \\
\text { Caolinita } \\
\text { Gibbsita } \\
\text { (ōx. e hidrōx.de Fe) } \\
\text { + caolinita } \\
\text { Gibbsita } \\
\text { Quartzo }\end{array}$ & $\begin{array}{l}\text { Bauxita Caolinitica } \\
\text { Argila Bauxitica } \\
\text { Argila (Caolim) }\end{array}$ \\
\hline
\end{tabular}

FIGURA 21 - QUADRO SIMPLIFICADO DA EVOLUÇÃO DOS MATERIAIS ESTUDADOS 
sendo mais jovem que a superficie; considerando que esta pode es tar jă algo rebaixada, a alteração poderia ser muito mais jovem que a superfície.

Jà em Mogi das Cruzes, a situação $\bar{e}$ bem diversa: os fragmentos e restos de crostas ou couraças encontradas nas cotas mais altas evidenciam a contribuição de material bauxitiza do e encouraçado em altitudes superiores, posteriormente desmantelado e removido at $\vec{e}$ a posição atual. 0 material estudado, portanto, sofreu uma primeira fase de alteração em tempos anteriores à formação da superfĩcie neogēnica. Desta forma, a alteração atual age sobre um material $j \vec{a}$ alterado, mais antigo que a super fĩcie que o suporta, o que caracteriza o caräter secundārio da bauxita ou da laterita formada.

Com respeito à bauxitização do material taludiano em Lavrinhas, o aspecto a ser discutido se refere a uma alteração anterior ou posterior à formação do tälus, jā que a idade do pröprio tālus não estä ainda definida com segurança.

A bauxitização do tälus è um processo contīnuo, tendo atuado sobre o material ainda "in situ", e apōs a sua descida. Contudo, a fase de bauxitização maior responsāvel pela for mação das jazidas parece-nos ter ocorrido apös a estabilização do material ao pë do Maciço, o que contraria as idëias expostas por Sigolo (1979). A morfologia dos depósitos, com matacões de dimensões avantajadas, ultrapassando os $5 \mathrm{~m}$, totalmente bauxitizados e conservando, sem perturbações, as estruturas originais da rocha sugere que este material foi bauxitizado jā na sua posi ção atual. Este ponto de vista baseia-se na consideração de que um material deste tipo, não teria resistido intacto a um movi mento de massa de tal porte, mesmo sendo um movimento lento, em meio plástico.

A existência de matacões totalmente bauxitizados ao lado de outros apenas incipientemente bauxitizados na sua periferia, assim como a presença de depósitos quase estēreis ao lado de outros altamente mineralizados, são fatos justificados pela drenagem interna dos perfis, ou seja, pela dinâmica da ăgua, diferente em cada porção do tälus, e diferente em cada pon 
to do mesmo perfil. Esta irregularidade da percolação $\vec{e}$ que provo cou a alteração diferencial, que não deve, a nosso ver, ser usada como argumento a favor de uma bauxitização anterior à formação do tālus. Da mesma forma, a alteração de natureza caolinitica das rochas do embasamento não significa que a bauxitização não se desenvolve atualmente de maneira intensa, mas simplesmente atesta que as condições litolōgicas dificultam uma perfeita bauxitização, atingida apenas nas rochas alcalinas, onde o baixo teor em silica não representa um grande obstäculo.

A alternāncia de condições mais secas e mais ümidas no clima durante o Quaternārio Superior tem sido indicada em värios trabalhos, como Bigarella e Ab'Saber (1964), Bigarella e Mousinho (1965), Bigarella (1971), entre outros. Este comportamen to do clima, associado a certos aspectos observados na ärea, como a existência de grandes espessuras de bauxita no lado näo tectoni zado do Maciço Alcalino, e na existência de caolinita na matriz argilosa do tälus, leva-nos a uma interpretação da sequéncia dos fenōmenos de alteração na ārea: em fase anterior, de clima mais seco, a alteração sobre o maciço não era muito intensa e incluía a caolinização dos minerais, muito embora houvesse tambēm a gibbsitização, pelo favorecimento do controle litolögico. Assim, o material escorregado era constituído por blocos sãos com matriz caolinitica-gibbsitica. Hoje, em clima mais ümido, sobre o maciço, - processo de bauxitização é intenso, a partir das rochas sãs e a partir da caolinita formada anteriormente, e sobre o tälus, tambëm ocorre uma bauxitização intensa dos blocos e matacões rola dos, a partir de sua periferia, que representa superfícies de des continuidade favorāveis à percolação preferencial, ao passo que a caolinita da matriz ainda subsiste, por estar inserida em meio relativamente menos lixiviante, ou seja, a matriz argilosa, em posições topogräficas mais baixas em relação ao maciço.

Em resumo, a conclusão è de que parte do material desceu ja bauxitizado, mas o processo continuou ainda mais intensa mente, formando expressiva porcentagem do minērio apös a formação do tälus. 
AGRADECIMENTOS

Apös concluĩda a apresentação desta dissertação de mestrado, cabe lembrar vārias pessoas e entidades que tiveram todos sua parcela de responsabilidade pela realização do trabalho, às quais registro aqui minha sincera gratidão.

Ao Prof. Adolpho Josē Melfi, pela orientaçäo,pe los ensinamentos que me transmitiu, pelo amplo apoio em todos os momentos do desenvolvimento do trabalho.

Aos professores do Instituto de Geociēncias-USP, durante o curso de Graduação e de Pōs-Graduação, a quem devo minha iniciação na geologia, e de quem obtive sempre o apoio necessärio e oportuno.

A Missão ORSTOM no IGUSP, especialmente ao Prof. Dr. Jean-Marie Wackermann, que com dedicação acompanhou viagens ao campo, orientou a utilização da Espectrografia de Emissão, e principalmente deu assistência total e constante nos estudos de Microscopia Optica. Ao Dr. Jean Delvigne,tambëm pelo auxilio na Microscopia Optica. Ao Dr. Armand Chauvel, pela orien tação na tēcnica de impregnação das amostras friāveis e obtenção das fotomicrografias. Enfim, a todos estes e ainda aos Drs.Jean - Jacques Trescases, Boris Volkoff e Jean-claude Parisot, a presença constante e auxîlio nos trabalhos de laboratōrio e na obtenção de bibliografia. Ao quĩmico Sylvain Raymond Locati, pela orientação nas anālises quĩmicas.

Ao geōlogo Joel B.Sigolo, que acompanhou os tra balhos de campo em Lavrinhas, transmitindo suas experiencias na região.

Ao engenheiro Dr.Jesuĩno Felicissimo Jr., que auxi liou os trabalhos de campo em Curucutu.

A Empresa de Mineração B.F.Lopes, que autorizou a visita aos depösitos de Mogi das Cruzes, e cedeu os dados obtidos durante a pesquisa feita pelo engenheiro Alceu F.Barbosa. 
As geögrafas May $C$.Modenesi, que enriqueceu o trá balho com crîticas e sugestões, e Maria Tereza Nöbrega, que tạm bëm esteve presente com seu apoio em vārias oportunidades.

A Flāvia, Dino, Sidrónia e Irāclito, colegas e amigos, que muito facilitaram o meu trabalho, e com sua amizade tornaram gratificante a minha permanência no Instituto.

A Anälia, Adilson, Andrē, Cleide, Mārio e Neide, pelo auxīito no Laboratōrio de Geoquímica e de Difração de Raios$X$; à D.Melany e Cläudio pela cuidadosa confecção das lâminas delgadas.

A equipe da Biblioteca do I.G., D.Ruth, Dulce, Beth, Stela e Terezinha, à equipe da Secretaria de Pōs-Graduação, D.Nair e Madalena, às secretārias do Departamento de Geologia Geral, claudete e Lourdes, pela simpatia com que sempre me atende ram.

A FAPESP, cujo apoio financeiro foi imprescindi vel, e ao CNPq, que tambëm participou financeiramente nos ültimos meses do trabalho.

Aos que participaram na execução da forma final do trabalho: Jaime, pelo cuidado com que trabalhou nas fotogra fias, D. Itacy e Walter, na execução dos desenhos, a equipe gräf ca do IG, e a Sra. Claudete, pelo zelo na datilografia final.

Finalmente, a minha gratidão a meus pais, Leinha e Wilson, cujo apoio incondicional, durante todo o tempo e em todos os aspectos, foi fundamental para o inicio, desenvolvimento e conclusão não só desta dissertação, mas de todas as minhas realizações. A eles, e ainda a Henrique e Felipe, meus filhinhos, e ao Mauro, dedico este trabalho. 
B I BL I OGRAF I A

AB'SABER, A.N. - 1954 - "A geomorfologia do Estado de São Paulo" IBGE, Cons.Nac.Geogr., Rio de Janeiro, p. 1-97.

AB'SABER, A.N. - 1958 - "0 sītio urbano de São Paulo" in "A cida de de São Paulo, estudos de geografia urbana" cap.5, vol.1, AGB, Cia.Ed.Nac., São Paulo, p. 169-245.

AB'SABER, A.N. - 1969 - "Ritmo da epirogênese pōs-cretācica e se tores da superfícies neogênicas em São Paulo". Geomorf., 13: 15. IGEOG, USP.

ALMEIDA, F.F.M. - 1958 - "0 Planalto Paulistano" in "A cidade de São Paulo, estudos de geografia urbana" cap.4, vol.1,AGB, Cia.Ed.Nac., São Paulo, p. 113-167.

ALMEIDA, F.F.M. - 1964 - "Fundamentos geolögicos do relevo paulișta". IGG, Bo1.41, São Pau1o, p. 167-263.

ALMEIDA, F.F.M. - 1976 - "The system of Continental Rifts bordering The Santos Basin, Brazil" - An.Acad.Bras.Ciēncias, supl. 48 , p. 15-26.

AMADOR, E.S. - 1975 - "Estratigrafia e Sedimentação na Bacia de Resende, RJ" - Simp.Int.Quat., An.Acad.Bras.Ciências, 47, p. $180-191$.

ANDRIESSE, J.P. - 1969 - "The influence of the nature of parent rock on soil formation under similar atmosferic climates" Soil and tropical weathering - Proceedings of The Bandung Symposium - Natural Resources Research XI UNESCO.p. 95-140.

BARDOSSY, Gy. - 1970 - "Comparaison des bauxites de karst" - An. Inst.Geol. Publ. Hungarici-v.LIV, 3 .

BARDOSSY, Gy. - 1979 - "Growing significante of bauxite" EPISO DOS, $1979, \mathrm{n} ! 2$. 
BARDOSSY, Gy. - 1981 - "Paleoenvironments of laterites and Tateritic bauxites - Effect of global tectonism on bauxite formation" Proc.Int. Sem. Later. Proc. -Trivandrum, India, 1979. 0xford \& IBH Pub1. Co., p. 287-294.

BELINGA; S.E. - 1972 - "L'alteration des roches basaltiques et le processus de bauxitisation dans 1'Adamaoua (Cameroun)" Tese Univ.Paris VI.

BERNER, R.A. - 1977 - "Rate control of mineral dissolution under earth surface conditions. Proceed. of the Soc. Int. Symp. on water-rock interaction, Strasbourg 1977, section IV, p. IV1 - IV -13 .

BIGARELLA, J.J. e AB'SABER, A.N.- 1964 - "Palyogeographische und Paldoklimatische aspekte des Kanozoikums in sud-brasilien". Zeitschrift fur Geomorphologie, 8(3):286-312.

BIGARELLA, J.J. e MOUSINHO, M.R.-1965 - "Considerações a respei to dos terraços fluviais, rampas de colüvio e vārzeas". Bol. Paran.Geogr., $(16-17): 153-197$.

BIGARELLA, J.J. - 1971 - "Variações climäticas no Quaternārio Su perior do Brasil e sua datação radiomëtrica pelo mētodo do Carbono 14. Bol. Inst. Geogr. USP, sërie Paleoclimas. São Pauto, 1. 22p.

BISDOM, E.B.A. - 1967 - "The role of microcrack systems in the spheroidal weathering of an intrusive granite in Galicia (NW Spain)" Geologie in Mijnbouw-46.

BOCQUIER, G. (1976) - "Synthëse et perspectives: migration et accumulations de l'aluminium et du fer" Bull. Soc. Gēol. France, (7) t. XVIII no 1: 69-74.

BOCQUIER, G. (1979) - "Importance des microsystems dans les ëvolutions supergēnes - Introdution" Bu11. Ass.Franc. pour 1' ètude du Sol, Sëmin.Alt. des roches cristallins, 1978, Versailles, nọ 2 e 3 . 
BONIFAS, M. - 1959 - "Contribution à l'ētude gēochimique de l'a] tëration latëritique". Mëm.Serv.Carte Gëol.A1s.-Lorr., Strás bourg, $17,159 \mathrm{p}$.

BOULANGE,B.;PAQUET, H.et BOCQUIER,G. - 1975 - "Gëochimie de la surface - Le rōle de l'argile dans la migration et l'accumulation de l'alumine de certaines bauxites tropicales" ,C.R. Acad. Sc. Paris, t. 280 .

BOULET, R. - 1974 - "Modalitēs d'action du lessivage dans les sols tropicaux dēveloppēs sur granites (Haute-volte). Etude micromorfologique". Cah.ORSTOM, sër. Pëdologie, Vol.x nọ 4.

BREWER, R. - 1964 - "Fabric and mineral analysis of soil" $\mathrm{J}$. Wiley and sons.

BROWN, G. - 1972 - "The X-ray identification and crystal structu res of clay minerals" - Min. Soc. London, $544 \mathrm{p}$.

CAILLERE, S.; HENIN, S.e BIROT,P.- 1957 - "Sur la formation tran sitoire de montmorilitonite dans certaines altērations latéritiques."C.R.Acad. Sci. Paris, 244, 788-791.

CAILLERE, S. e POBEGIUN, Th. - 1964 - "Considērations sur la gēnēse des bauxites de la France mëridionale". C.R.Acad. Sci Pa ris, t. 262, p. 1661-1664.

CARROL, D. - 1970 - "Rock weathering". Plenum Press, N.York.

CHATELIN, Y. - 1972 - "Les sols ferrallitiques" - t.1- Init.Doc. Tech. nọ 20 - ORSTOM - Paris.

CHATELIN, Y. - 1974 - "Les sols ferrallitiques" t.3 - Init. Doc. Tech. no 24 - ORSTOM, Paris.

CHAUVEL, A. - 1979 - "Curso de Micromorfologia do Solos" - IG USP, mimeogr.

CORRENS, C.M. e VON ENGELHARDT, W. - 1938 - "Neue intersuchungen Uber die Verwitterung des kalifeldspates" - Chemie der Erde $12,1-22$. 
- CORDANI, U.G., COIMBRA, A.M., BOTTURA, J.A. e RODRIGUES, E.L.M.1974 - "Geologia da Região de Cruzeiro e Cachoeira Paulista, e sua importância na interpretação da evolução tectōnica do Vale do Paraỉba" - Geologia Ciência Técnica - CEPEGE, IG-USP (6), $9-30$.

DELMAS, A.B. - 1979 - "Apport de 1 a cinêtique dans 1 a connaissan ce des phēnomēnes d'altēration". Bul1. AFES, Sēm.Alt.Roches, 1978, Versailles, nọ 2 e 3.

DELVIGNE, J. - 1965 - "Pedogēnēse en zone tropicale.La formation des minēraux secondaires en militieu ferrallitique". Mëm.orsToM paris.

DELVIGNE, J. - 1977 - "Micromorphologie des processus d'altēra tion des roches ultrabasiques de Côte D'Ivoire en vermiculite, montmorillonite et kaolinite". I Reunion Int.Suelos -Gra nada.

DE MARTONNE, E. - 1943-44 - "Problemas morfolögicos do Brasil Tropical Atläntico" - Rev.Bras.Geogr. 5(4): 523-547 e 6(2): $155-175$.

DUCHAUfOUR, PH. - 1965 - "Prëcis de Pëdologie" Masson et Cie. Paris.

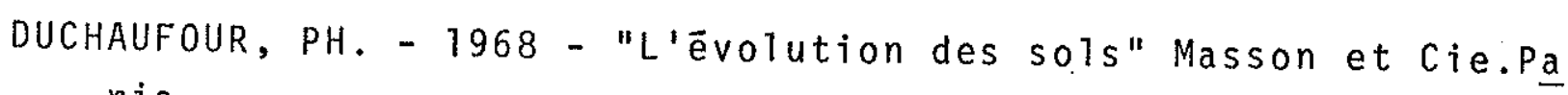
ris.

ERHART, H. - 1967 - "La gēnēse des sols en tant que phēnomēne gëologique" Masson et Cie.Paris.

ERHART, H. - 1973 - "Itinēraires gēochimiques et cycle de 1'aluminium" Doin, Paris.

ESWARAN, H., G. STOOPS E C. SYS - 1977 - "The micromorphology of gibbsite forms in soils" J. Soit Science, 28.

FELICISSIMO Jr., J; e FRANCO, R, R. - 1956 - "Bauxita no altiplano da Serra de Cubatão". Bol. SBG vol. V nọ 2. 
FoX, C.S. - 1932 - "Bauxite and aluminous laterite" The Chemical Press Ltd.

FRIPIAT, J.J. e HERBILLON, A.J.- 1971 - "Formation and transformation of clay minerals in tropical soils" Soil and Tropical Weathering - Proceedings of the Bandung Symposium - 1969 UNESC0, Nat.Res.Res., 11, p. 15-24, Paris.

FRITZ,B. e TARDY, Y. - 1976 - "Sëquences des minēraux secondai res dans l'altëration des granites et roches basiques. Modēles thermodinamyques". Bu11. Soc.Gëol. France, 18, 1, p. 7-12 .

GARDNER, L.R. - 1970 - "A chemical model for the origin of gib bsite from kaolinite". The Am. Min.vol.55.

GARRELS, R.M. e CHRIST, C.L. - 1965 - "Solutions, minerals and equilibria", Harper and Row, N.Y.

GARRELS, R.M. e HOWARD, P. - 1957 - "Reactions of feldspars and mica with water at low temperatures and pressures". Proc.Nat. Conf. Clays and Clay Minerals 6, p. 68-88.

GOLDSCHMIDTH V.M. - 1954 - "Geochemistry" - Clarendon Press, 0x ford.

GOMES, J.C.F. - 1956 - "Jazida de bauxita de Curucutu - SP". Rev. Esc. Minas, Ouro Preto, MG, vol.XX, jan./56, nọ 2, p. 7-16.

GONI, J. - 1966 - "Contribution à l'ëtude de la localisation et la distribution des ēlëments en traces dans les minēraux et les roches granitiques". Mëm. BRGM, 45.

GORDON, M. e TRACEY, J.I. - 1952 - "Origin of the Arkansas bauxi te deposits. Problems of clay and laterite genesis". Am. Inst. Min.Met., p. 12-34.

GORDON, M., TRACEY, J.I. e ELLIS, M.W. - 1958 - "Geology of the Arkansas bauxite region". U.S. Geol. Surv. Prof. Paper,299, $268 \mathrm{p}$. 
GOUDIE, A. - 1973 - "Duricrusts in Tropical and subtropical 1 and scapes". Clarendon Press - 0xford.

GRIM, R.E. - 1953 - "Clay Mineralogy" - MCGraw Hill Book Co.N.Y. GROKE, M.C.T.; MELFI, A.J. e WACKERMANN, J.M. - 1980 - "Transfor maçôes mineralögicas e estruturais ocorridas durante a bauxí tização de rochas cristalinas äcidas. Estudo do depösito bau xitico de Mogi das Cruzes, SP".Anais XXXI Congr.Bras. Geol., 1980, vol. 1, p. 128-135.

GRUBB, P.L.C. - 1970 - "Mineralogy, geochemistry and genesis of the Bauxite deposits on the Gove and Mitchel Plateaux, Northern Australia" Min. Dep. (Ber1.) 5: 248-272.

GUIMARAES, J.E.P. e KENWORTHY, J.S. - 1943 - "A bauxita de Mogi das Cruzes" - Rev. Polit. set./43.

HARRASSOWITZ, H. - 1926 - "Laterit", Fortschr. Geol. Paleontologie, Berlim, 4, 253-565.

HEINRICH, E.W. - 1956 - "Microscopy Petrography" - McGraw Hill Book Co. N.Y.

HELGESON, H.C. - 1968 - "Evaluation of irreversible reaction in geochemical process involving minerals and aqueous solutions I-Thermodynamic relation". Geochim. Cosmochim. Acta, $32, p$. $853-877$.

HELGESON, H.C.; GARRELS, R.M. e MACKENZIE, F.T. - 1969 - "I IApplications". Geochim. Cosmochim.Acta, 33, p. 455-481.

HENIN, S. e PEDRO, G. - 1979 - "Rōle de l'hëtērogēneitē minēralo gique du milieu sur les modalitës de 1'altëration" - Bull. AFES Sëm. L'Altēration des Roches Cristallines, 1978, Versailles no:2 e 3 .

HESS, P.C. - 1966 - "Phase equilibria of some minerals in the $\mathrm{K}_{2} \mathrm{O} \cdot \mathrm{Na}_{2} \mathrm{O}^{\mathrm{AT}} \mathrm{O}_{3} \cdot \mathrm{SiO}_{2} \cdot \mathrm{H}_{2} \mathrm{O}$ system at $250 \mathrm{C}$ and 1 atm" Am.J.Sci. vol. 264 . 
ILDEFONSE, Ph., PROUST, D., MEUNIER, A. e VELDE, B. - 1979 - "Rố le de la structure dans l'altēration des roches cristallines au sein de microsystēmes" - Bu11. AFES Sēmin. L'Alteration des Roches Cristallines - Versailles, 1978, no 2 e 3.

JENNY, H. - 1951 - "In origin of soils. Applied sedimentation".TRASK, p. 41-61, Wyley N.York.

KITTRICK, J.A. - 1969 - "Soil minerals in the $\mathrm{Al}_{2} \mathrm{O}_{3} \cdot \mathrm{SiO}_{2} \cdot \mathrm{H}_{2} \mathrm{O}$ sys tems and a theory of their formation" Clays and clay minerals vol. 17:157-167, Pergamon Press.

KNECHT, T. - 1952 - "A bauxita de Mogi das Cruzes" Min. e Met. vol. 16.

- KNECHT, T. - 1940 - "Bauxita, diversos lugares nos municĩpios da capital e Itapecerica" Bol. IGG no 27, p. 51-52.

KRAMER, J.R. - 1970 - "Mineral water equilibria in silicate weathering" XXVIII Int.Geol. Congress - Prague (6).

KRAUSKOPF, K.B. - 1956 - "Dissolution and Precipitation of silica at low temperatures" Geoch.Cosm. Acta, 10:1-27.

KRAUSKOPF, K.B. - 1972 - "Introdução à geoquĩmica" - Polĩgono EDUSP, São Paulo.

LAMEGO, A.R. - 1949 - "A faixa costeira de Vitöria" Bo1.DGM-DNPM no 128 .

LELONG, F.; TARDY, Y.;GRANDIN, G.; TRESCASES, J.J. e BOULANGE,B. - 1976 - "Pedogenesis, chemical weathering and processes of formation of some supergene ore deposits" Reprinted from Handbook of Strata-bound and stratiform ore deposits. Else vier Scient. Co.,Chap.3, p. 93-173, Amsterdam.

LINDSTAEDT, H.P. - 1972 - "A alteração das rochas alcalinas - La ges - SC" - Seminärio UFRS (datilogr.).

LENEUF, N. - 1959 - "L'altëration des granites calco-: alcalins 
et des granodiorites en Côte-d'Ivoire forestiēre et les sols qui en sont derives". $210 \mathrm{p}$. Th.Paris.

LING ONG, A. - 1971 - "Correlation between chemical bond and chemical weatherability of the common rock-forming minerals" Soil and Tropical weathering - Proceedings of the Bandung Symposium - 1969, UNESCO, Paris.

LOUGHNAN, F.C. e BAYLISS, P. - 1961 - "The mineralogy of the bauxite deposits near Weipa, Queensland", Am.Miner. 46, p. 209-217.

LOUGHNAN, F.C. - 1969 - "Chemical weathering of the silicate minerals" - Elsevier Scient. Publ.Co., N.York.

MACKENZIE, R.C. - 1957 - "The differential thermal investigation of clays". Min.Soc. London, $456 \mathrm{p}$.

MAIGNIEN, R. - 1961 - "Sur les argiles noires tropicales d'Afrique Occidentale". Bull.spēcial, Ass.Fr.Et. Sol, 131-144.

MASSARD, P. - 1977 - "Approche termodynamique des phēnomēnes de dissolution. Aspect cinētique en systēme ouvert". Bul1. Soc. Fr. Min. Crist., 100, p. 177-184.

MASON, B.H. - 1971 - "Princĩpios de geoquímica" Poligono-EDUSP, São Paulo.

MAYANZA, E.C. - 1977 - "Solubilisation de la silice a partir du quartz et de la kaolinite - Individualisation de la gibbsite dans les sols" Thëse Univ. Paul Sabatier de Toulouse (Scien ces).

MELFI, A.J. - 1967 - "Intemperismo de granitos e diabäsios no Municipio de Campinas e arredores, Estado de São Paulo". Tese de doutoramento - Fac.Fil.Ciên.Letras-USP, São Paulo.

MELFI, A.J. e LEVI, F. - 1971 - "Geochemical and mineralogical study on the first stages of weathering of basic and related rocks" - Part I - Rev.Bras.Geoc., Vol.I. 
MELFI, A.J.; CORDANI, U.G.; CARVALHO, A.; MINIOLI, B.; PENALVA, F.; BASEI, M.A.S. e COUTINHO, J.M.V. - 1976 - "Geologia das Folhas de Lorena e Cruzeiro" - Convēnio DNPM e Inst.Geoc.USP $77 \mathrm{p}$.

MELFI, A.J. e PEDRO, G. - 1977 - "Estudo geoquímico dos solos e formações superficiais do Brasil" Parte I - Rev. Bras.Geoc. Vol. 7 nọ 4 .

MEUNIER, A. - 1977 - "Les mecanismes de l'altēration des granites et le rōle des microsystēmes - Thēse Univ. Sci. Poitiers.

MICHARD, G. e FOUILLAC, C. - 1974 - "Evaluation des transferts d'ëlëments au cours des processus d'altēration des mine raux par des fluides". C.R. Acad. Sci. Paris, 278 D, p. 2727-2729.

MILLOT, G. e BONIFAS, M. - 1955 - "Transformations isovolume triques dans les phēnomēnes de latēritisation et bauxitisa tion". Bul1. Serv. Carte Gëol. Als. Lorr., 8,1, p.3-20.

MILLOT, G. - 1964 - "Geōlogie des argiles" - Masson et Cie,Paris.

Millot, G.; BOCQUIER, G. e PAqUET, H. - 1978 - "Gëochimie et paysages tropicaux" (datilogr.).

MODENESI, M.C. - 1980 - "Intemperismo e morfogēnese no Planalto de Campos do Jordão-SP". Rev.Bras.Geoc., vol.10, p.213225.

MONIZ, A.C. - 1969 - "Estudo mineralögico de argilas do Maciço Alcalino de Poços de Caldas" FFCL-USP Bol. 304 - Minera logia nọ 19 .

MOORHOUSE, W.W. - 1959 - "The study of rocks in thin section"Harper and Brothers, N.Y.

MORAIS, L.J. - 1943 - "Bauxita em Mogi das Cruzes" Min.e Met. no 38, vol.7. 
NORTON, S.A. - 1973 - "Laterite and bauxite formation" Econ.Geol. $68: 353-361$.

NOVIKOFF, A. - 1974 - "L'altēration des roches dans le massif du Chaillu (Rēp.Pop.du Congo), formation et ëvolution des argites en zone ferralitique" Thëse Univ. Louis Pasteur de Strasbourg.

OLIVEIRA, S.M.B. - 1980 - "Alteração Intempērica das rochas ultrabāsicas de Santa $F \bar{e}(G O)$ e Gēnese do depösito niquelífero". Tese Dout. I.G.-USP, São Paulo.

OLWEILLER, D.A. - 1974 - "Quĩmica Analitica Quantitativa" vol. 3. Livros Tëcnicos e Cientïficos Editora S.A., R.J.

PEDRO, G. - 1964 - "Contribution à l'ētude expērimentale de T' altëration chimique des roches cristallines." Thèse Doc. Fac.sci. Paris.

PEDRO, G. - 1966 - "Essai sur la caractērisation gēochimique des differents processus zonaux de l'altēration superficielle des roches". C.R.Acad. Sci. Paris, 292-D, p. 1828-1831.

PEDRO, G - 1968 - "Distribution des principaux types d'altēra tion chimique à la surface du globe. Presentation d'une esquisse gēographique". Rev.Geogr.Phys. et Gēol. Dyn., X, 5, p. 457-470.

PEDR0, G. - 1976 - "Synthēse et perspectives: altērations mëtēoriques et argiles" - Bull. Soc.Gëol.France (7), t.XVIII nọ 1 .

PEDRO, G. - 1979 - "Caractërisation gënērale des processus de l'altëration hydrolitique". Bu11. AFES - Sëm. Alt. Roches, 1978, Versailles, nọ 2 e 3.

PEDRO, G. e DELMAS, A.B. - 1980 - "Regards actuels sur les phēno mēnes d'altēration hydrolytique. Leur nature, leur diversitêe et leur place au cours de t'evolution gëochimique superficielle". (datilogr.). 
PELLOUX, P.; DABIN, B.; FILLMANN, G. e GOMEZ, P. - 1971 -

thodes de dëtermination des cations ëchangeables et de la capacité d'ëchange dans les sols". Inst.Doc.Tech., 17, ORSTOM Paris.

PENALVA, F. - 1967 - "Geologia e tectōnica da região do tiaia" - Bol. FFCL-USP - 302 (Geologia-22) - São Paulo.

PETROVIC, R.; BERNER, R.A. e GOLDHABER, M. - 1976 - "Rate control in dissolution of alkali feldspars. I study of res $i$ dual feldspars grains by $X$-ray photoelectron spectroscopy"Gēochim.Cosmochim. Acta. 40, p. 537-548.

PINT0, M.S. - 1937 - "Bauxita" - Rev.Eng.Min.Met., 2, (8).

PINTO, M.S. - 1938 - "Descoberta de ocorrēncias de bauxita no Itatiaia" - Rev.Eng.Min.Met., 3 (15).

PROUST, D. - 1976 - "Etude de l'altération des amphibolites de la Roche-l'Abeille. Evolutions chimiques et minëralogiques des plagioclases et des hornblendes". Thèse $3 \mathrm{e}$. cycle, no 605 , Poitiers, $85 \mathrm{p}$.

RANKAMA, K. e SAHAMA, T.0. - 1950 - "Geochemistry" - Univ.Chica go Press.

- RIBEIRo Fo, E. - 1967 - "Geologia e Petrologia dos Maciços Alca linos do Itatiaia e Passa-Quatro".Bol. FFCL-USP 302 (Geologia-22), São Paulo.

SEDDOH, F. - 1973 - "Altēration des roches cristallines du Morvan". Mëm. Gēol. Univ.Dijon, 337p., multigr.

SEgALEN, P. - 1957 - "Etude de sols dērivēs de roches volcani ques basiques à Madagascar". Mëm. Inst.Sci.Madagascar, 0,8 , p. $1-195$.

SEGALEN, P. - 1971 - "Metal1ic oxides and hydroxides in soils of the warm and humid areas of the world: formation, ident $i$ fication, evolution". Soils and Trop.weath-Proc.of the Ban-. dung Symp., 1969, UNESCO, Paris. 
SIGOLO, J.B. - 1979 - "Geologia de depōsitos residuais bauxiticos na região de Lavrinhas - SP, e sua viabilidade econōmica". Diss. Mestrado IG-USP, São Paulo.

STEVENS, R.E. e CARRON, M.K. - 1948 - "Sample field test for distinguishing minerals by abrasion $\mathrm{pH}^{\prime}$. Ann. Min., vol.33.

STOOPS, G.; ALTEMULLER, H.J.; BISDOM, E.B.A.; DELVIGNE, J.; DOBROVOLSKY, V.V.; FITZPATRICK, E.A.; PANEQUE, P. e SLEEMAN,J.1979 - "Guidelines for the description of mineral alterations in soil micromorphology". Pedologie, XXIX, 1. Ghept.

SUGUI0, K. - 1969 - "Contribuição à Geologia da Bacia de Taubate" - Tese Doutoramento FFCL-USP, Boletim especial I.

SUSZCZYNSKI, E.F. - 1978 - "New bauxitic ore deposits in, the oriental portion of the Brazilian Shield" $-4^{\text {th }}$ ICSOBA vol.2, Athens.

TARDY, Y. - 1969 - "Gēochimie des altërations. Etude des arēnes et des eaux de quelques massifs cristallins d'Europe et 'd' Afrique". Mëm.Serv.Carte Gēol. Als. e Lorr., 31, 199p.

TRESCASES, J.J. - 1975 - "L'ēvolution gëochimique supergēne des roches ultrabasiques en zone tropicale" - Mém.ORSTOM, nọ 78 , 259 p., Paris

TRICHET, J. - 1969 - "Contribution à l'ētude de l'altäration experimentale des verres volcaniques". Thēse Doc.Fac.Sci.Paris, $232 \mathrm{p}$.

VALENTON, I. - 1972 - "Bauxites" - Elsevier Sci. Publ.Co.,Amsterdam.

VALENTON, I. - 1973 - "Considerations for the description and nomenclature of bauxite" - ICSOBA, 1973.

VERBEKE, R. - 1969 - "Sur un procēde de fabrication de lames minces dans des roches peu cimentëes et des soles" - Bull. Soc. Gëol. de France (7)-XI- p. 426-433. 
WACKERMANN, J.M. - 1975 - "L'altēration des massifs cristallins basiques en zone tropicale semihumide. Etude minēralogique et gēochimique des arēnes du Senegal oriental. Consequences pour la cartographie et la prospection". Thèse Sc, Strasbourg, $373 p$.

WEBER, B.N. - 1959 - "Bauxitização no distrito de Poços de Cal das, MG, Brasill. Bol. SBG., vol.8, no 1.

WOLLAST, R. - 1967 - "Kinetics of the alteration of K-feldspar in buffered solutions at low temperatures". Geochim.Cosmoch. Acta 31 , p. 635-648. 
FOTOGRAFIA 
FOTOMICROGRAF I AS

FOTOMICROGRAFIA 1 - Amostra MC-2, L.P., aumento 17,5X Resīduo de plagioclāsio em vias de alteração, ainda visīvel o limite entre duas maclas. Jā hă gibbsita preenchendo cavidades dissolvidas e fissuras do plagioclāsio.

FOTOMICROGRAFIA 2 - Amostra MC-3, L.P., aumento 17,5 X Muscovita caolinizada, com as lamelas deformadas e separadas, e assemblēia de grãos de quartzo, alguns trincados e corroi dos cimentados por gibbsita. No plasma predominantemente gibbsītico, fragmentos de muscovita em vias de caolinização ou jā caolinizados.

FOTOMICROGRAFIA 3 - Amostra MC-3, L.N., aumento 17,5 X Segregação do ferro do retïculo cristalino da biotita, que se posiciona sob a forma de óxidos ou hidrōxidos, nos contornos dos cristais e entre as lamelas.

FOTOMICROGRAFIA 4 - Amostra MC-3, L.P., aumento 17,5 X Preservação das descontinuidades dos feldspatos pela formação de gibbsita nestes locais, resultando numa rede de geodos de gibbsita separando cavidades vazias (poros).

FOTOMICROGRAFIA 5 - Amostra MC-3, L.P., aumento 17,5 X Muscovita deformada em leque, caolinizada, em processo de gibbisitização. As partes mais claras representam a gibbsita resultante da alteração da caolinita.

FOTOMICROGRAFIA 6 - Amostra MC-3, L.P., aumento 17,5 X Assemblēia de grãos de quartzo, cimentados por gibbsita. Alguns grãos encontram-se trincados, corroỉdos, e invadidos pela gibbsita. 0 fundo matricial é essencialmente gibbsītico. 


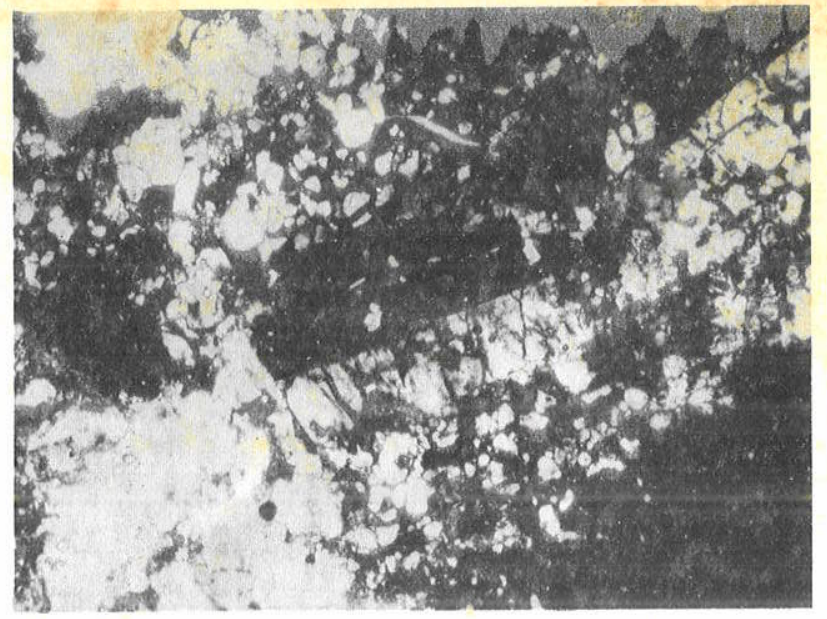

FOTOMICROGRAFIA 1

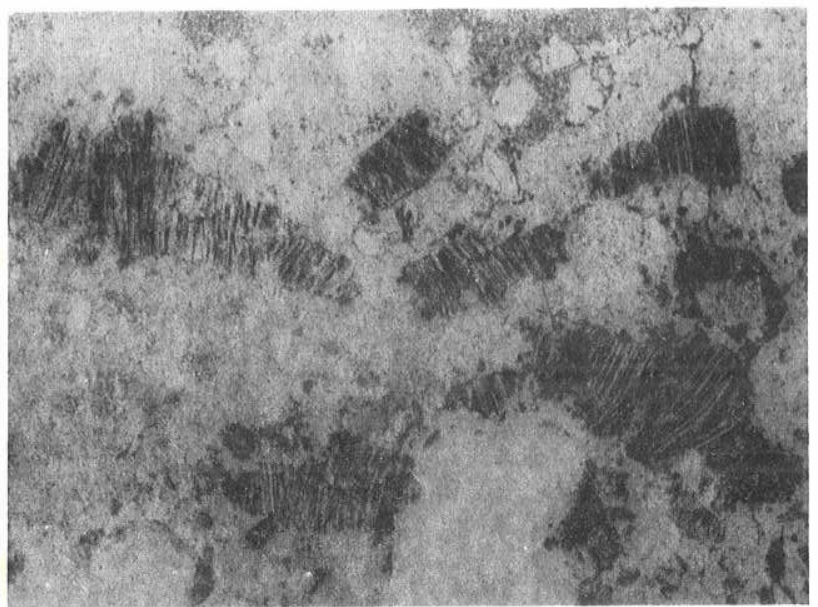

FOTOMICROGRAFIA 3

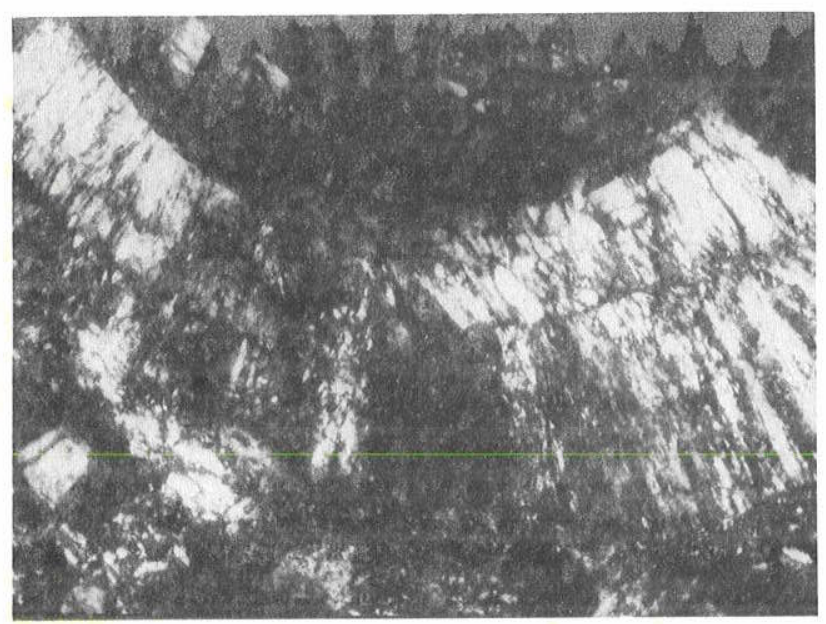

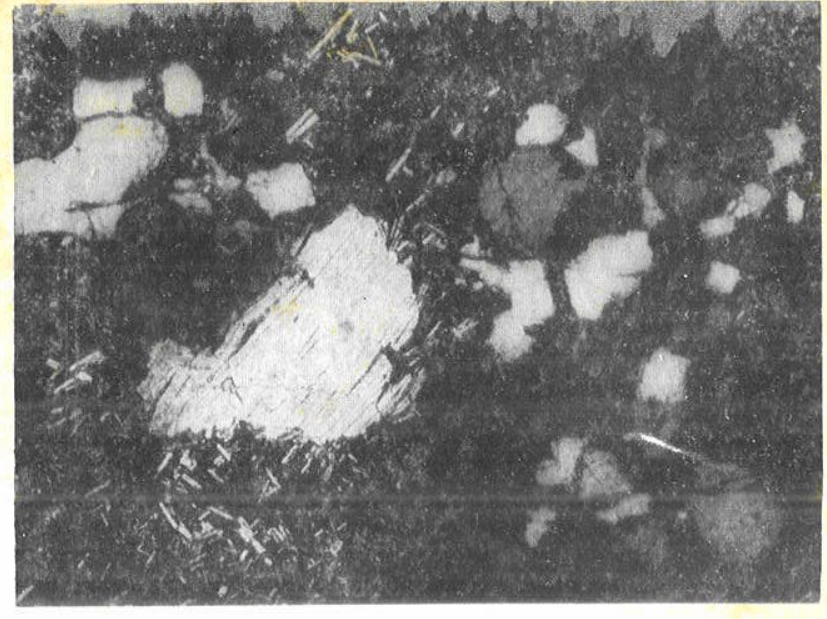

FOTOMICROGRAFIA 2

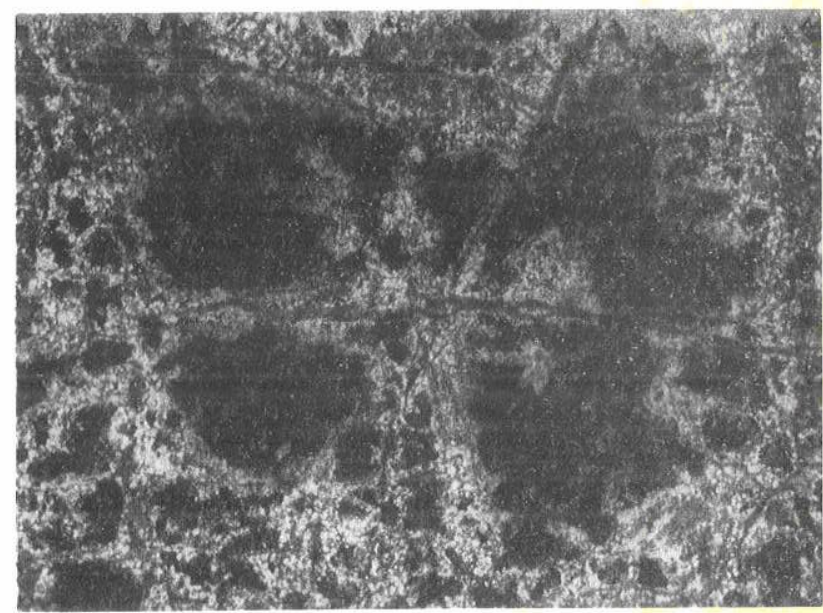

FOTOMICROGRAFIA 4

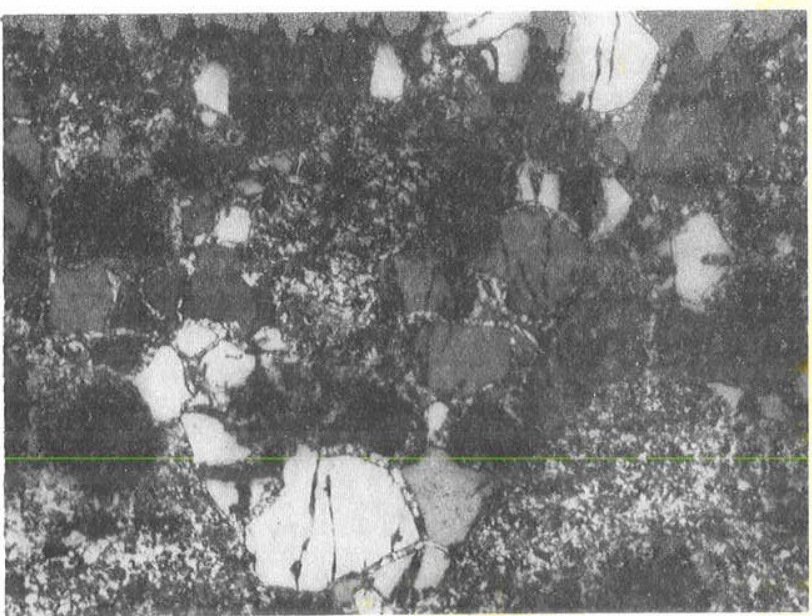

FOTOMICROGRAFIA 6 
FOTOMICROGRAFIA 7 - Amostra MC-3, L.P., aumento 17,5 X

Detalhe da alteraçào do quartzo; cristal apresentando trincas, sinais de corrosão e invasão por material secundārio (gibbsita e óxidos de ferro).

FOTOMICROGRAFIA 8 - Amostra SC-3, L.P., aumento 17,5 X Fantasmas de plagioclásio, gibbsitizados. Apōs a gibbsitização, restaram os contornos nitidos dos antigos cristais de plagioclásios, tendo sido lixiviados o seu interior e os outros minerais primārios.

FOTOMICROGRAFIA 9 - Amostra SC-3, L.N., aumento 17,5 X

Relíquia de olivina, cujo bordo de reação (piroxênio) teve tam bēm sua estrutura preservada. Dentro da olivina goethitizada, as fissuras são sublinhadas por magnetita, endógena. A relíquia estā circundada por fantasmas de piroxênios e anfibölios, e por gibbsita.

FOTOMICROGRAFIA 10 - Amostra SC-5, L.P., aumento 17,5 X Mesmo aspecto da fotomicrografia 9.

FOTOMICROGRAFIA 11 - Amostra SC-4, L.P., aumento 17,5 X Reliquias de piroxēnios e anfibōlios, conservadas pelos ōxidos de ferro que sublinham as clivagens e demais descontinuidades. A porosidade anteriormente existente, encontra-se preenchida por gibbsita bem cristalizada, que precipitou-se após a migração de partes topograficamente mais altas.

FOTOMICROGRAFIA 12 - Amostra SC.5, L.P., aumento 17,5 X cutanes gibbsiticos, ou geodos de gibbsita, no interior da porosidade dos fantasmas de piroxēnios e anfibötios. 


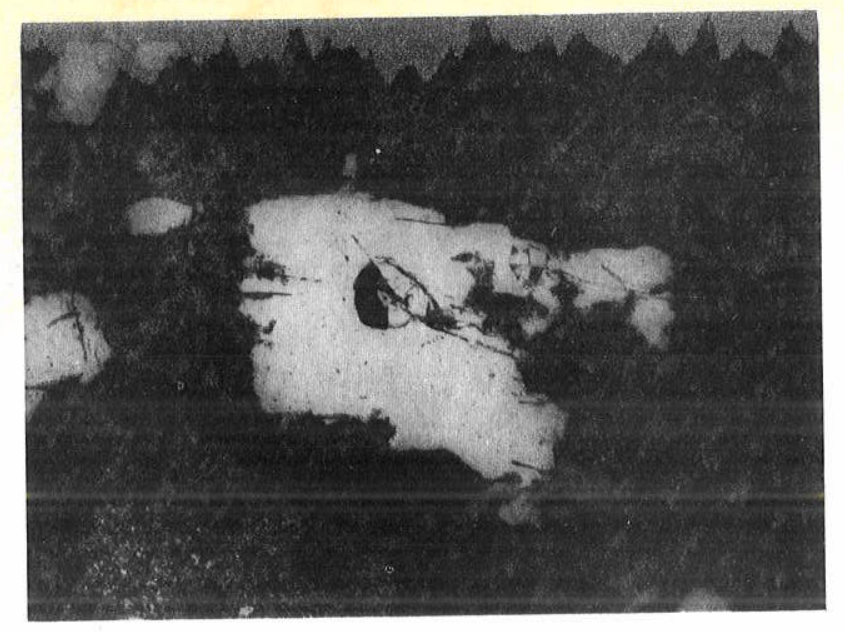

FOTOMICROGRAFIA 7

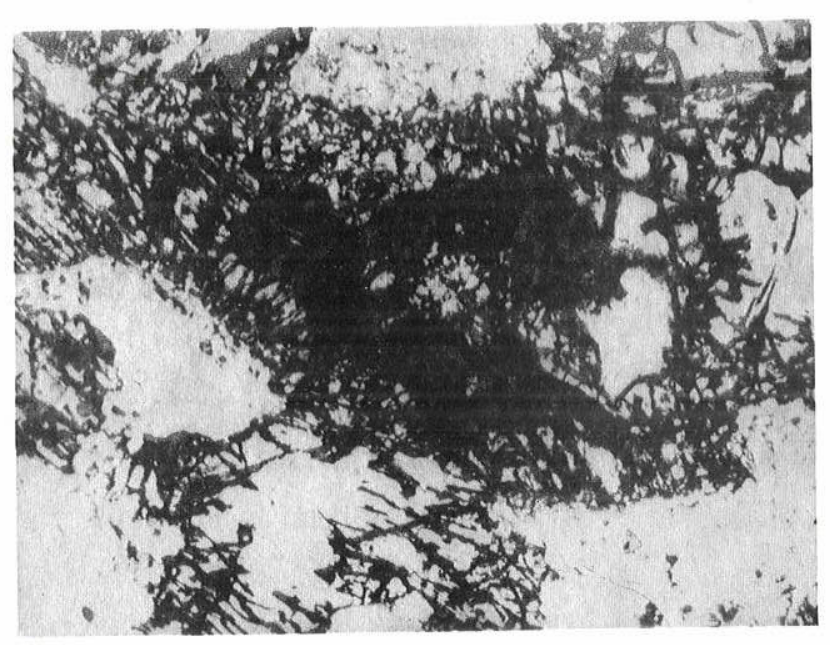

FOTOMICROGRAFIA 9
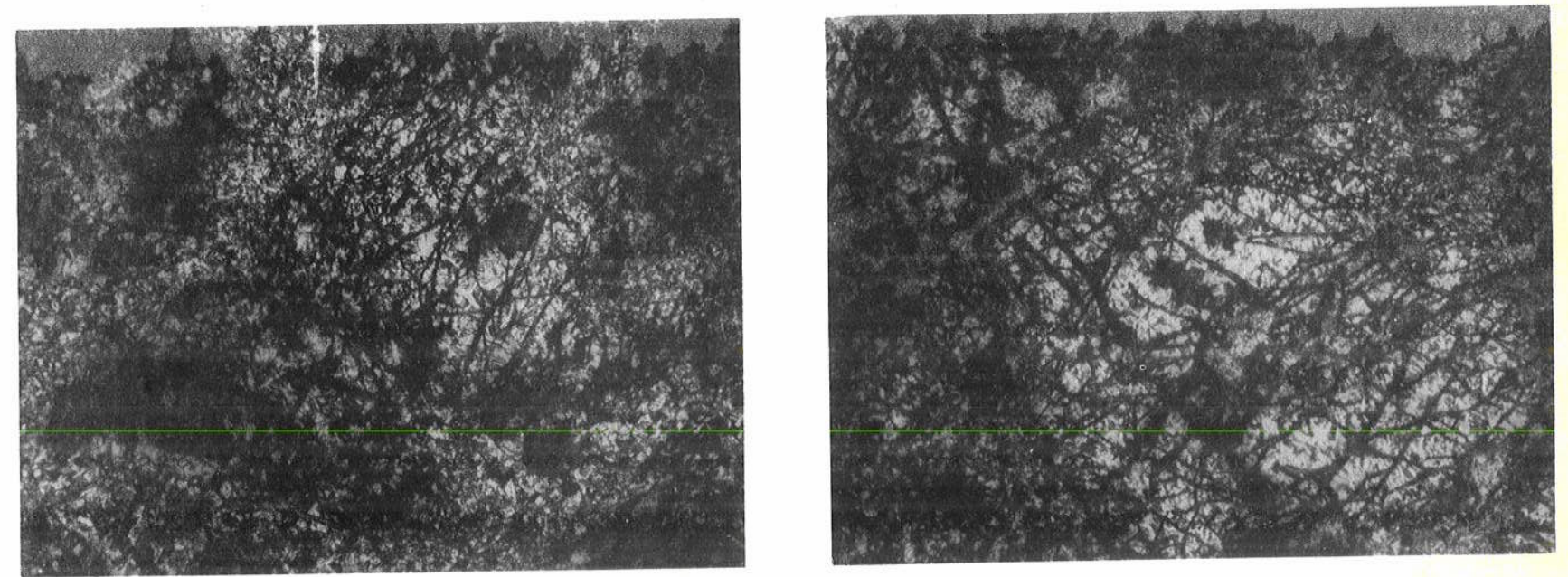

FOTOMICROGRAGIA 11

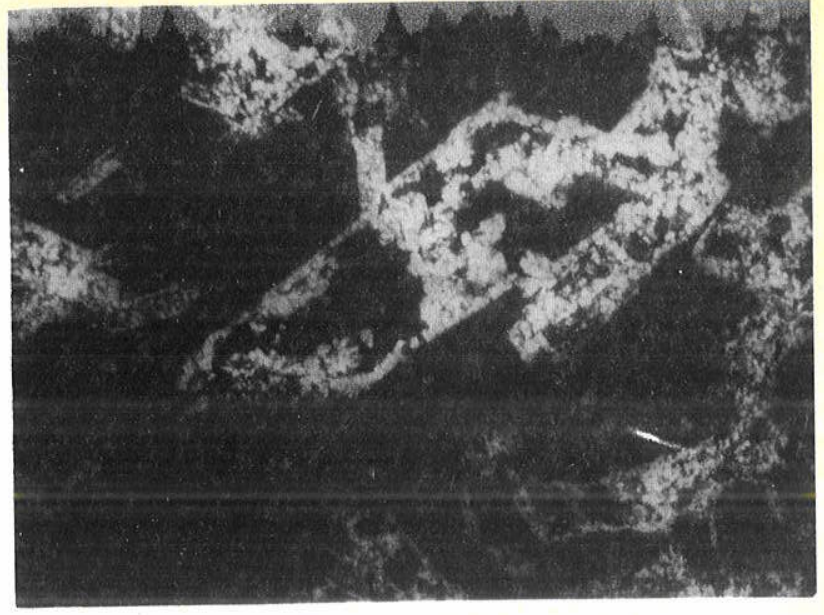

FOTOMICROGRAFIA 8

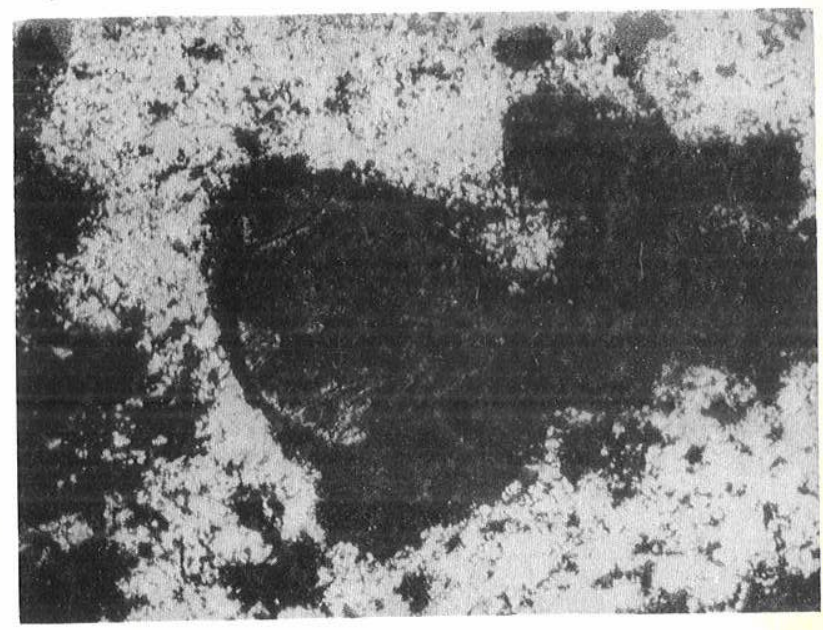

FOTOMICROGRAFIA 10

FOTOMICROGRAFIA 12 
FOTOMICROGRAFIA 13 - Amostra SC-5, L.P., aumento 17,5 X

Deformação dos fantasmas de ferromagnesianos (piroxênios e anfibōlios), pela deposição de gibbsita nos vazios.

FOTOMICROGRAFIA 14 - Amostra SC-5, L.P., aumento 17,5 X

Remobilização da gibbsita, formando gibbsanes e preenchendo a porosidade dos fantasmas de ferromagnesianos.

FOTOMICROGRAFIA 15 - Amostra SC-5, L.P., aumento 17,5 X

Depósito gibbsîtico macroscópico (gibbsane), circundado por fantasmas de ferromagnesianos, invadidos por gibbsita em seus poros.

FOTOMICROGRAFIA 16 - Amostra S-2, L.P., aumento 17,5 X

Feldspato em processo de alteração, que se instala nas descontinuidades, onde se forma a gibbsita.

FOTOMICROGRAFIA 17 - Amostra S-2, L.P., aumento 17,5 X

Gibbsita preservando o padrão de descontinuidades do antigo feldspato.

FOTOMICROGRAFIA 18 - Amostra S-3, L.P., aumento 17,5 X Três formas de ocorrēncia da gibbsita sobre rochas alcalinas: à esquerda, gibbsita primāria, guardando o padrão de desconti nuidades do feldspato; à direita, gibbsita primāria guardando o padrão de descontinuidades de feldspatóides, e embaixo, à direita, gibbsita secundāria, sem preservar nenhuma estrutura. 


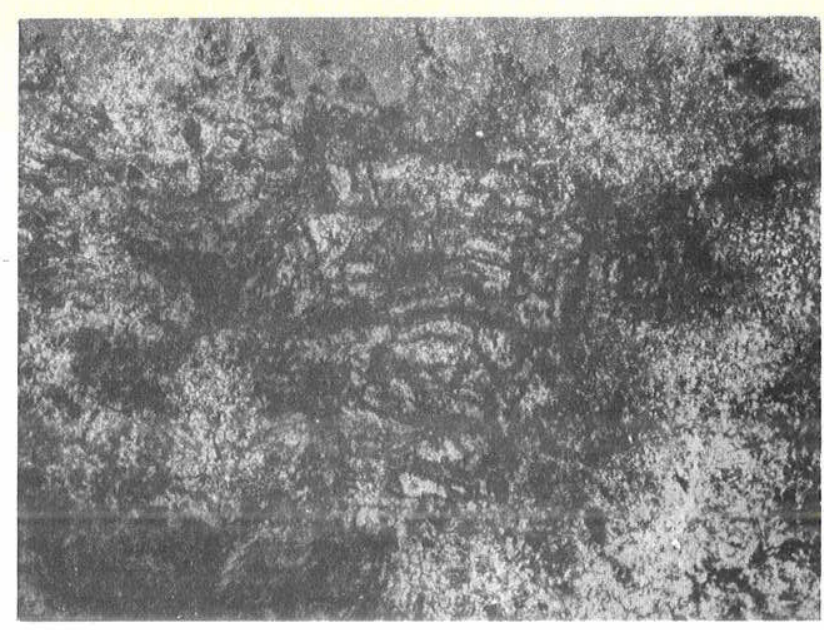

FOTOMICROGRAFIA 13

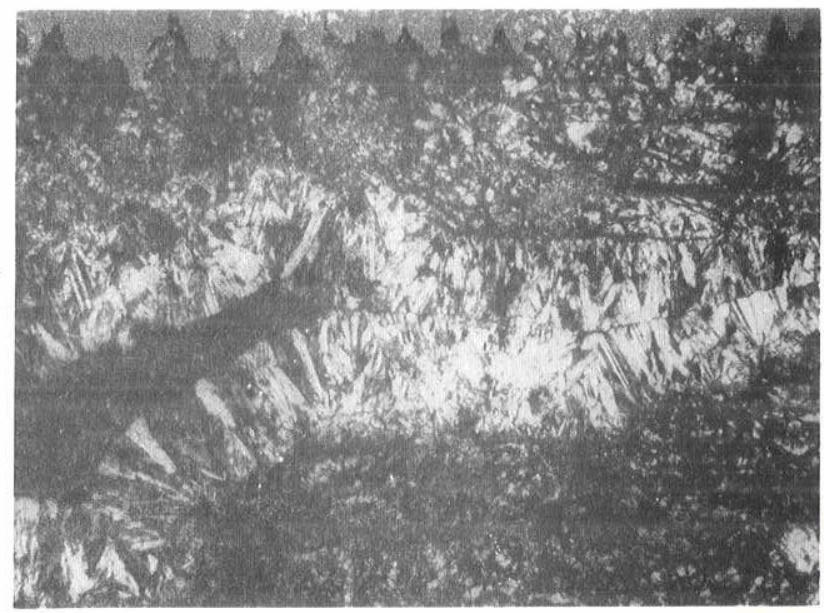

FOTOMICROGRAFIA 15

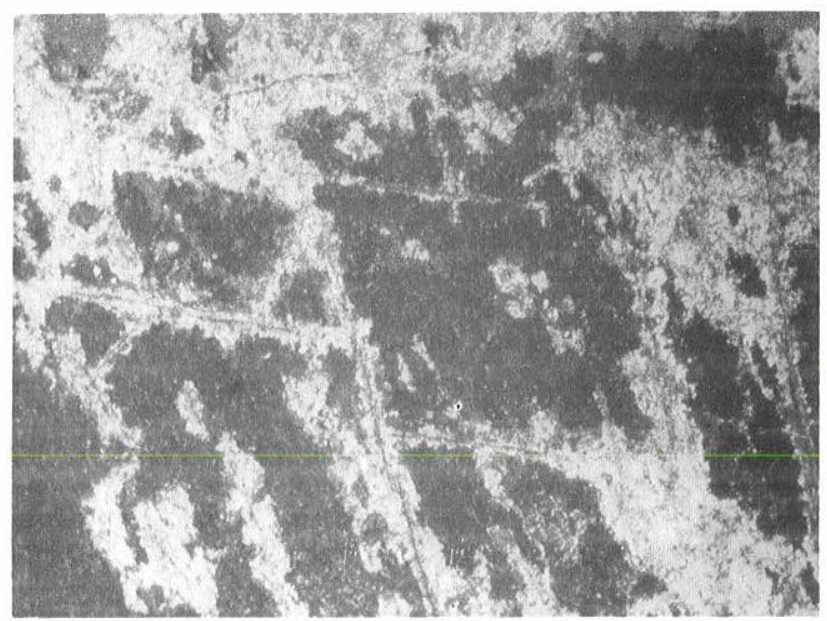

FOTOMICROGRAFIA 17

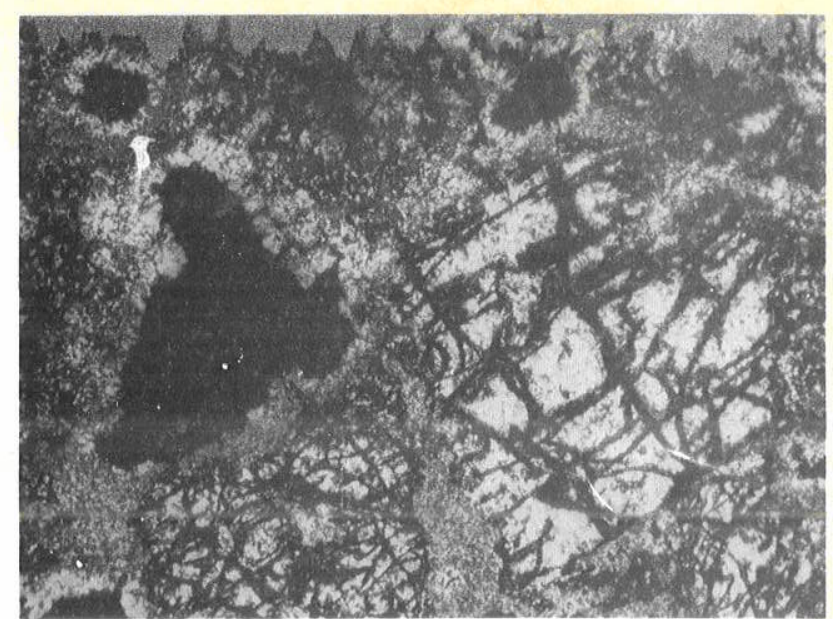

FOTOMICROGRAFIA 14

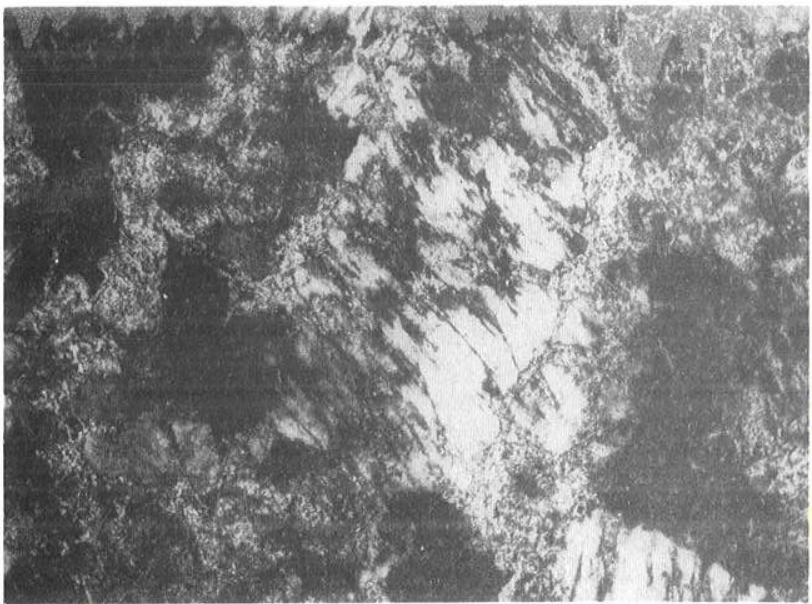

FOTOMICROGRAFIA 16

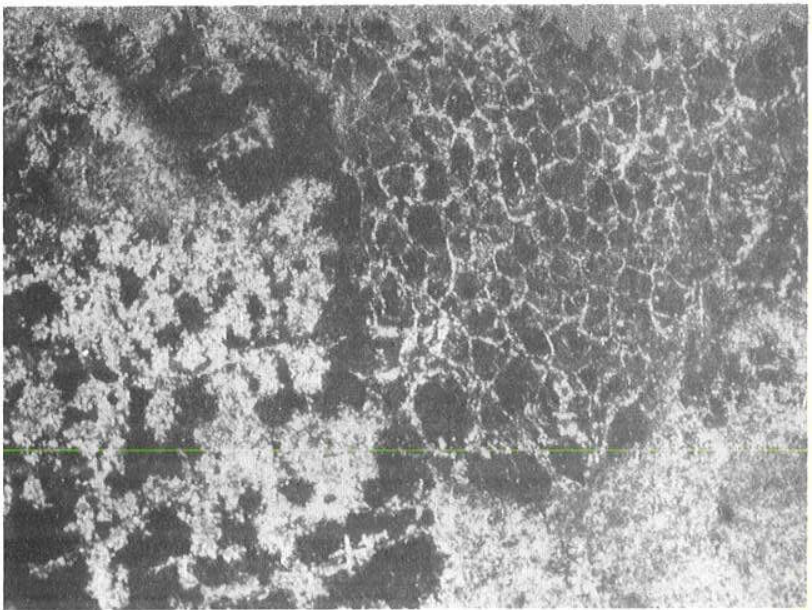

FOTOMICROGRAFIA 18 


\section{FOTOGRAFIAS}

Foto 1 - Mogi das Cruzes. Visão geral do relevo.

FOT0 2 - Mogi das Cruzes. Concreções bauxỉticas, vermiformes, con centradas superficialmente, após retirada dos horizon tes superiores do solo.

FOT0 3 - Curucutu. Visão geral do relevo.

F0T0 4 - Curucutu. Antiga exploração de bauxita ferruginosa para pavimentação de estradas, já desativada.

FOTO 5 - Lavrinhas. 0 morro à direita pertence ao tälus do maciço de Passa-Quatro, jā dissecado pela erosäo. Ao 1ongo do rio, observa-se blocos e matacões de rochas alcali nas.

FOT0 6 - Lavrinhas. Aspecto de uma das jazidas em exploração,com separação manual dos blocos bauxiticos. A matriz argilo sa nesta ārea apresenta teores de $\mathrm{Al}_{2} \mathrm{O}_{3}$ de até $38 \%$.

Foto 7 - Lavrinhas. Visão geral da jazida da foto 6 .

FOT0 8 - Mogi das Cruzes. Parede de trincheira, mostrando de baj xo para cima, material alterado conservando a estrutura da rocha, bauxita terrosa amarela e horizontes argilo sos concrecionārios.

FOTO 9 - Mogi das Cruzes. Corte resultante da retirada das camadas superficiais. De baixo para cima, observa-se material friāvel é ferruginoso apresentando bolsões de bauxita terrosa amarela e seixos de quartzito,horizonte en couraçado, duro e solo argiloso rico em quartzo e ferro.

FOT0 10 - Lavrinhas. Frente de lavra da jazida das fotos 6 e 7. Em cima, solo argiloso amarelo desenvolvido sobre o material do tálus, matriz argilosa comblocos de alcalinas bauxitizadas e grande matacão inalterado, camada de sei xos qibbsiticos, e novamente matriz argilosa com blocos bauxitizados. 


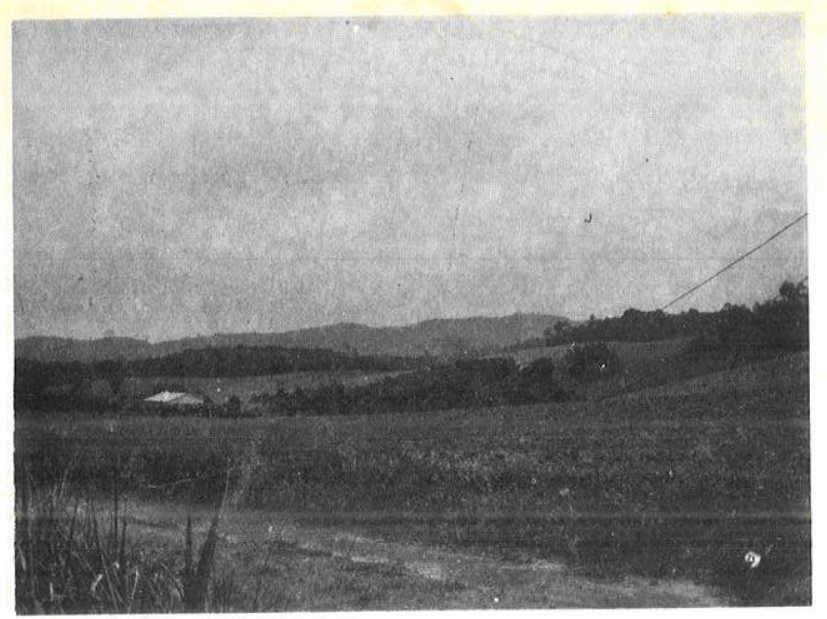

FOTO 1

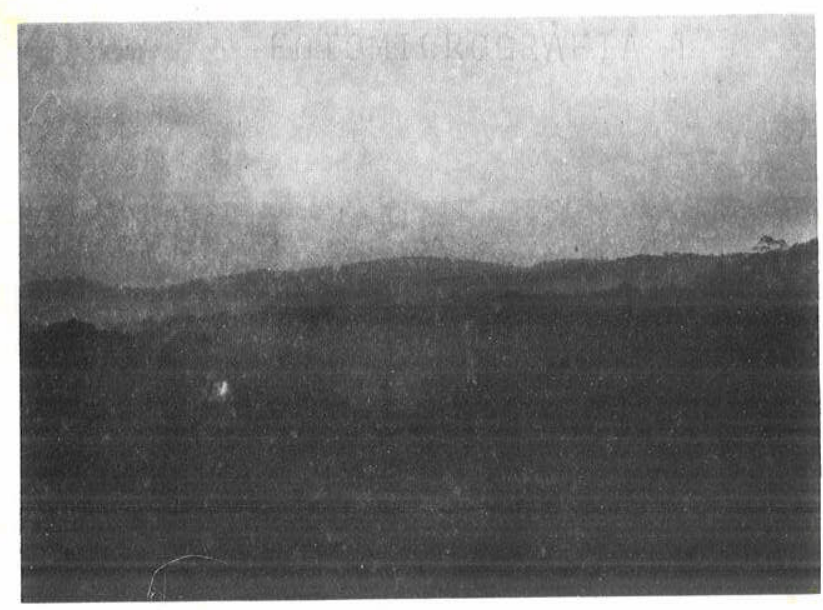

FOTO 3

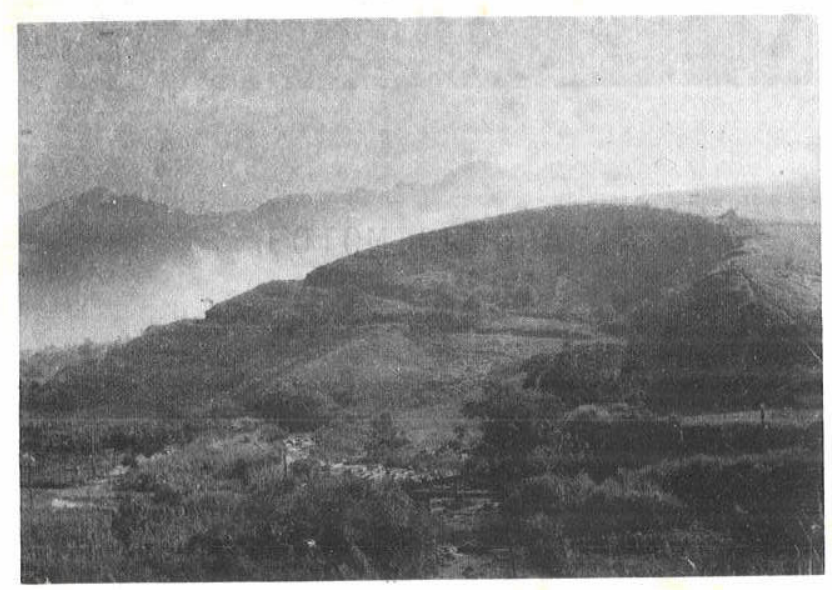

FOTO 5

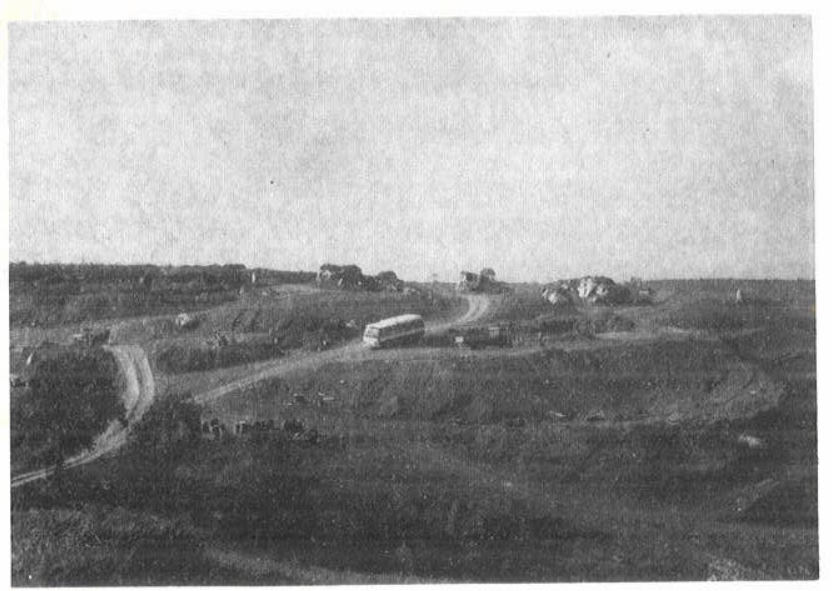

FOTO 7

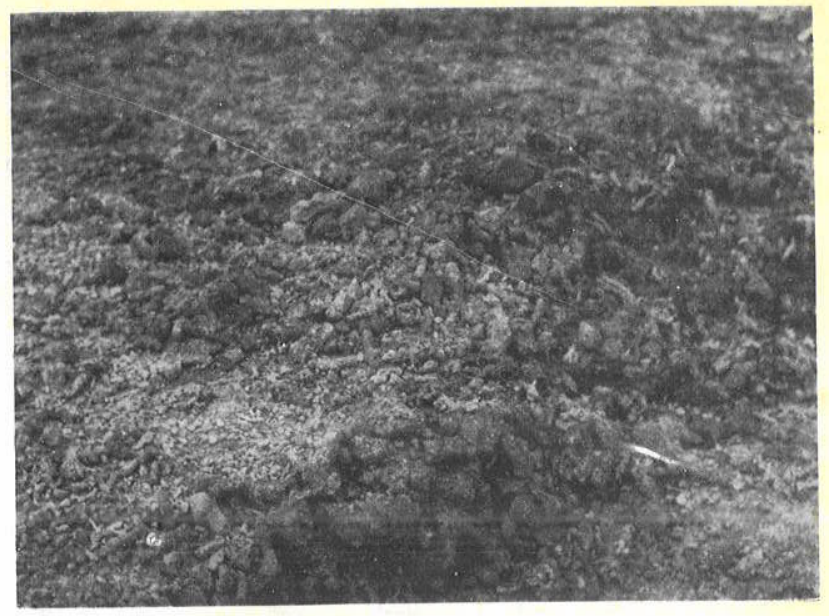

FOTO 2

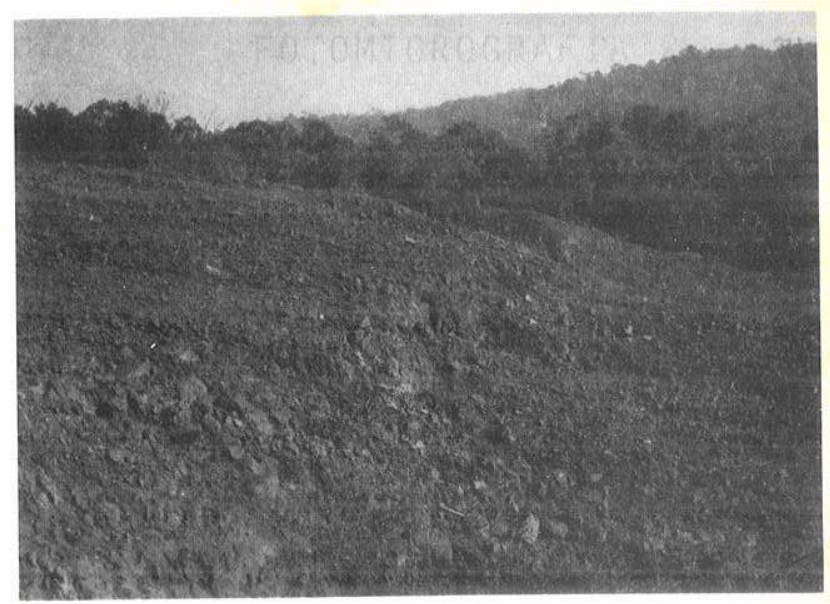

FOTO 4

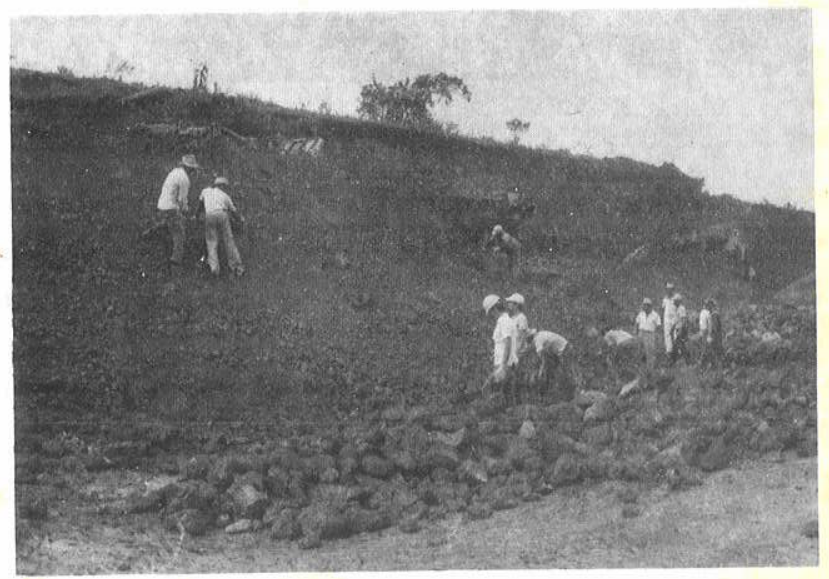

FOTO 6 


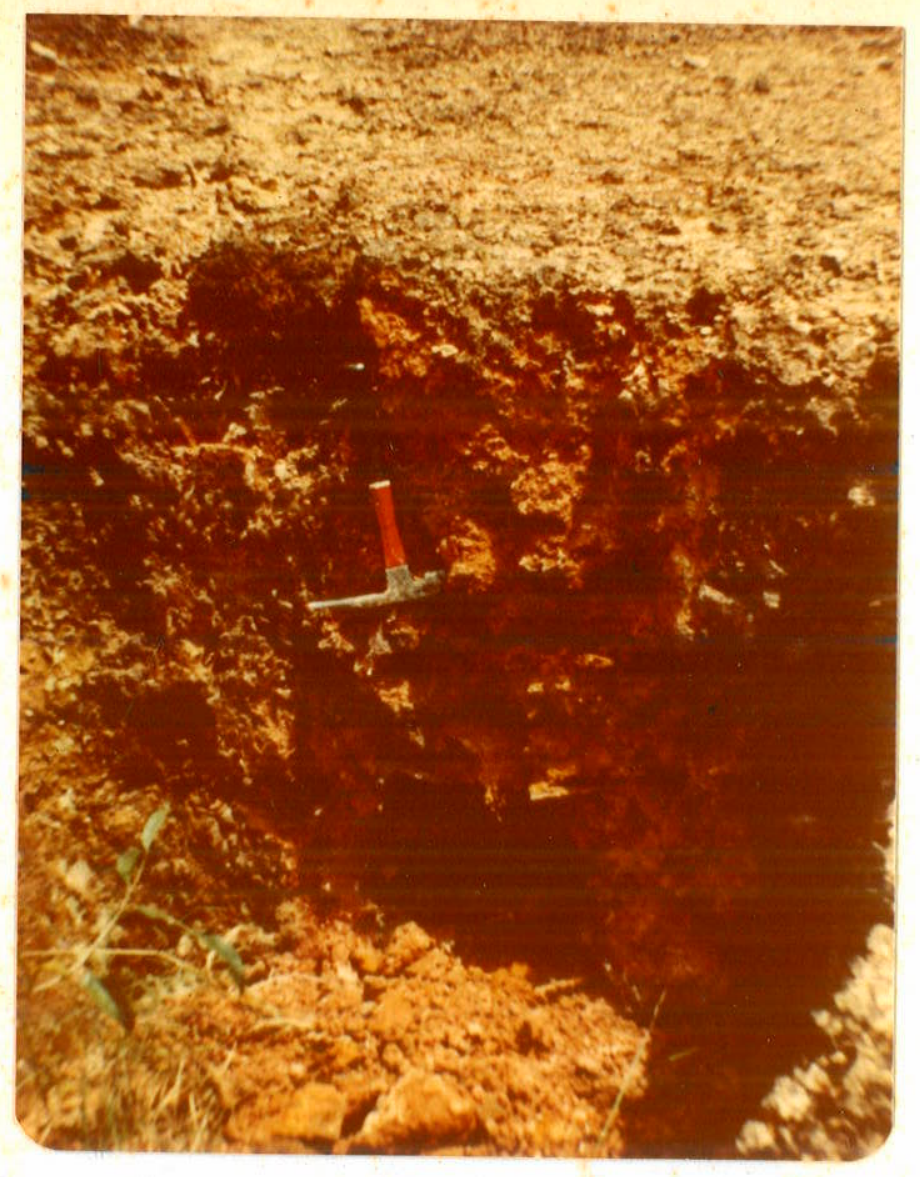

FOTO 8

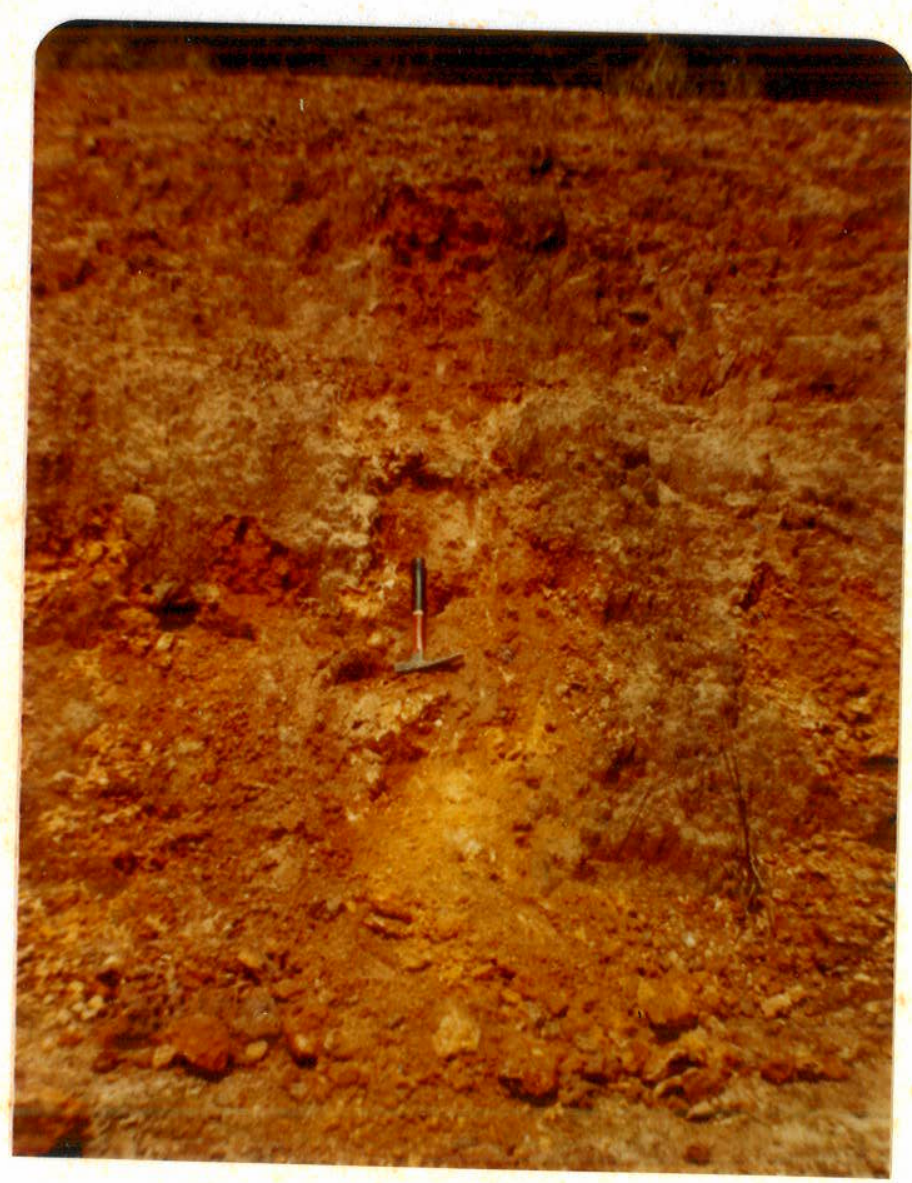




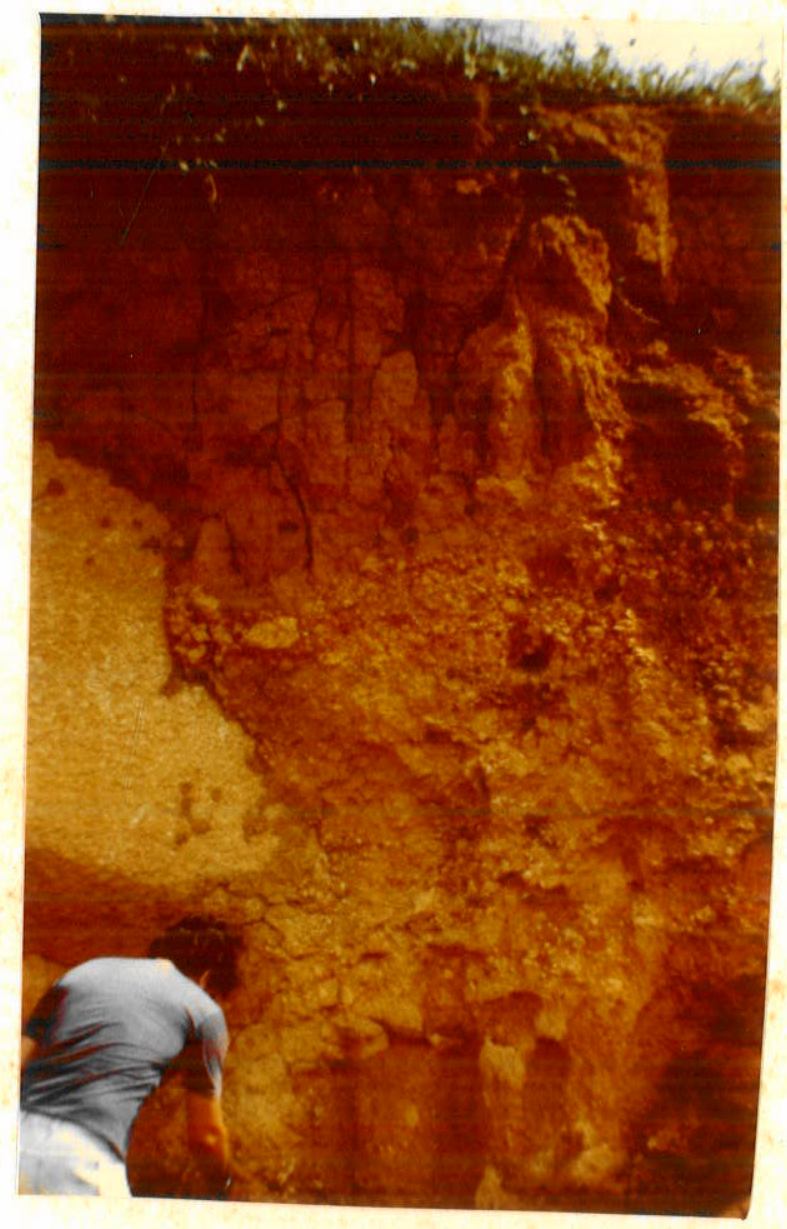

FOTO 10 